\title{
Quantifying Overwash Flux in Barrier Systems: An Example from Martha's Vineyard, Massachusetts, USA
}

\author{
by \\ Emily A. Carruthers \\ B.A. Earth Sciences, Boston University, 2009 \\ Submitted in partial fulfillment of the requirements for the degree of \\ Master of Science in Marine Geology and Geophysics \\ at the \\ MASSACHUSETTS INSTITUTE OF TECHNOLOGY \\ and the \\ WOODS HOLE OCEANOGRAPHIC INSTITUTION \\ September 2011 \\ (C) 2011 Emily A. Carruthers. All rights reserved.
}

The author hereby grants to MIT and WHOI permission to reproduce and to distribute publicly paper and electronic copies of this thesis document in whole or in part in any medium now known or hereafter created.

Signature of Author:

Joint Program in oceanography/Applied Ocean Science and Engineering Massachusetts Institute of Technology and Woods Hole Oceanographic Institution

23 June 2011

Certified by:

Jeffery P. Donnelly

Associate Scientist, Department of Marine Geology and Geophysics Woods Hole Oceanographic Institution

Thesis Co-Supervisor

Certified

by:

Andrew D. Ashton

Assistant Scientist, Department of Marine Geology and Geophysics

Woods Hole Oceanographic Institution

Thesis Co-Supervisor

Certified and Accepted by:

Robert L. Evans

Senior Scientist, Department of Marine Geology and Geophysics

Woods Hole Oceanographic Institution

Thesis Co-Supervisor

Chair, Joint Committee for Marine Geology and Geophysics Massachusetts Institute of Technology and Woods Hole Oceanographic Institution 


\title{
Quantifying Overwash Flux in Barrier Systems: An Example from Martha's Vineyard, Massachusetts, USA
}

by

\author{
Emily A. Carruthers \\ Submitted to the Department of Marine Geology and Geophysics \\ on June 23, 2011 in partial fulfillment of the requirements for the \\ Degree of Master of Science in Marine Geology and Geophysics
}

\begin{abstract}
Coastal barriers are particularly susceptible to the predicted effects of accelerated of sea-level rise and the potential for increased impacts of intense storms. Over centennial scales, barriers are maintained via overtopping during storms, causing deposition of washover fans on their landward sides. This study examines three washover fans on the south shore of Martha's Vineyard using a suite of data including vibracores, ground penetrating radar, high resolution dGPS, and LiDAR data. From these data, the volumes of the deposits were determined and range from $2.1-2.4 \times 10^{4} \mathrm{~m}^{3}$. Two overwashes occurred during Hurricane Bob in 1991. The water levels produced by this storm have a return interval of $\sim 28$ years, resulting in an onshore sediment flux of $2.4-3.4 \mathrm{~m}^{3} / \mathrm{m} / \mathrm{yr}$. The third washover was deposited by a nor'easter in January 1997, which has a water level return interval of $\sim 6$ years, resulting in a flux of $8.5 \mathrm{~m}^{3} / \mathrm{m} / \mathrm{yr}$. These fluxes are smaller than the flux of sediment needed to maintain a geometrically stable barrier estimated from shoreline retreat rates, suggesting that the barrier is not in long-term equilibrium, a result supported by the thinning of the barrier over this time interval.
\end{abstract}

Thesis Co-Supervisor: Jeffery Donnelly

Title: Associate Scientist of Marine Geology and Geophysics Woods Hole Oceanographic Institution

Thesis Co-Supervisor: Andrew Ashton

Title: Assistant Scientist of Marine Geology and Geophysics Woods Hole Oceanographic Institution

Thesis Co-Supervisor: Robert Evans

Title: Senior Scientist of Marine Geology and Geophysics Woods Hole Oceanographic Institution 


\section{Acknowledgments}

I would like to thank my advisors, Jeff Donnelly, Andrew Ashton, and Rob Evans. Each of them provided invaluable assistance and encouragement at different stages of my degree work. I would also like to thank past and present members of the Coastal Systems Group for their assistance in the field, lab, and life: Sam Zipper, Michael Toomey, Stephanie Madsen, Richard Sullival, Anastasia Pilliouras, Andrew Desnoyers, Marshall Moore, Sarah Brody, Michaeline Nelson, Brent Lughino, Jim Sederberg, Aleja Ortiz, and Jon Woodruff. Andrea Hawkes provided a wonderful sounding board and dealt with sharing an office with me these past few months as I finished up and wrote. Skye Moret provided an amazing amount of support in the field and lab as well as being a fantastic friend. Phil Lane provided storm modeling, despite my often emailing at the last minute.

Access to the washovers on South Beach at Long Cove Pond and Big Homer's Pond was graciously provided by the Trustees of Reservations at the Long Pond Reservation. Access to the washover at Edgartown Great Pond was provided by Nancy and Jerry Kohlberg through their caretaker Kendra Buresch. Many thanks to the Martha's Vineyard Coastal Observatory, particularly Janet Fredericks, for allowing me to use the MVCO van on the island. William Wilcox of the Martha's Vineyard Commission provided a valuable resource on the dynamics of the Edgartown Great Pond inlet as well as providing the aerial photos of the that washover.

Duncan FitzGerald of Boston University taught my first course in Earth Sciences and got me interested in studying coastal geology. I'd also like to thank him for providing some of the background literature for this work. Byron Stone of the USGS provided valuable references and discussion on the glacial history of Martha's Vineyard as well as in depth scientific discussion.

I would not have been able to complete this work without the support of my parents, Mark and Lisa Carruthers. My sister, Abby Carruthers, and my cousin, Meredith Bailey, also provided encouragement and advice whenever I needed it (and sometimes when I thought I didn't need it). My $1^{\text {st }}$ cousin once removed, Paul Robbins, was a great help in providing insight into the Joint Program, tons of advice, and lots of lunches.

I would not be where I am today without the help of Christopher Hein. Not only has he supported me through applying to grad school, my classes at MIT, research, and writing my thesis (with amazing editing skills), but he has also gone to Martha's Vineyard to help me collect more field data and then been a great sounding board as I worked it up.

Funding for this research was provided by an Emery Fellowship through the Woods Hole Oceanographic Institution Academic Programs Office, the National Science Foundation (grants NSF-GEO-0815875 and NSF-OCE-0840894), and the Department of Defense Strategic Environmental Research and Development Program (contract W912HQ-09-C-0043). 


\section{Table of Contents}

$\begin{array}{lllllllllllll}\text { Abstract } & \ldots & \ldots & \ldots & \ldots & \ldots & \ldots & \ldots & \ldots & \ldots & \ldots & 3\end{array}$

$\begin{array}{lllllllllllll}\text { Acknowledgments } & \ldots & \ldots & \ldots & \ldots & \ldots & \ldots & \ldots & \ldots & \ldots & 4\end{array}$

$\begin{array}{llllllllllll}\text { 1. Introduction } & \ldots & \ldots & \ldots & \ldots & \ldots & \ldots & \ldots & \ldots & \ldots & 8\end{array}$

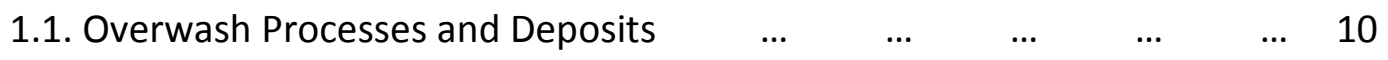

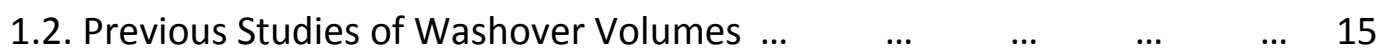

$\begin{array}{llllllllllll}\text { 2. Study Area } & \ldots & \ldots & \ldots & \ldots & \ldots & \ldots & \ldots & \ldots & \ldots & \ldots & 18\end{array}$

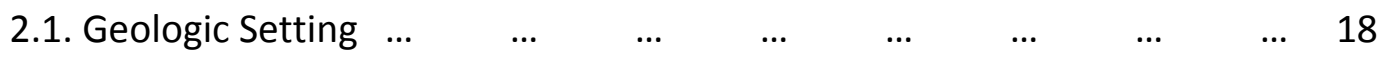

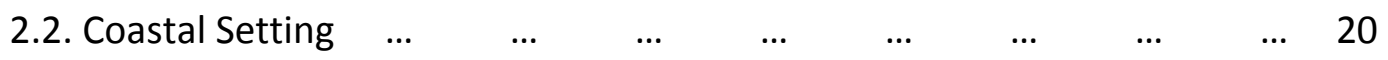

$\begin{array}{llllllllllll}\text { 3. Methods } & \ldots & \ldots & \ldots & \ldots & \ldots & \ldots & \ldots & \ldots & \ldots & \ldots & 27\end{array}$

$\begin{array}{lllllllllll}\text { 3.1. Field Methods } & \ldots & \ldots & \ldots & \ldots & \ldots & \ldots & \ldots & \ldots & 27\end{array}$

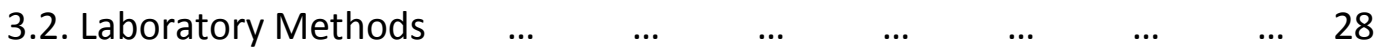

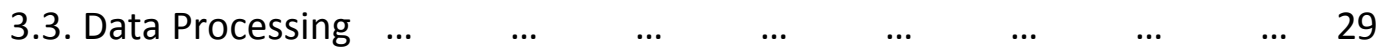

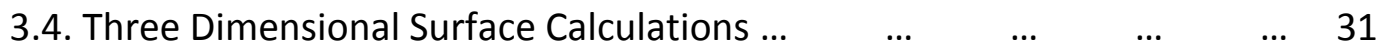

$\begin{array}{lllllllllll}\text { 3.5. Flux Calculations } & \ldots & \ldots & \ldots & \ldots & \ldots & \ldots & \ldots & & \ldots & 34\end{array}$

$\begin{array}{lllllllllllll}\text { 4. Results } & \ldots & \ldots & \ldots & \ldots & \ldots & \ldots & \ldots & \ldots & \ldots & \ldots & 35\end{array}$

$\begin{array}{lllllllll}\text { 4.1. Big Homer's Pond } . . & \ldots & \ldots & \ldots & \ldots & \ldots & \ldots & \ldots & 35\end{array}$

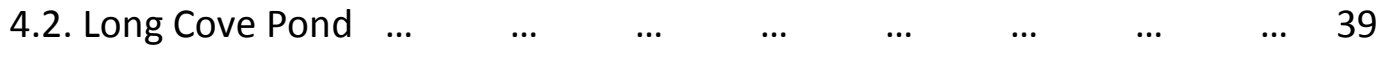

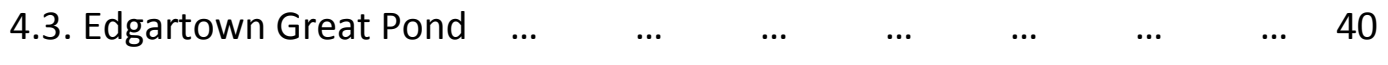

$\begin{array}{lllllllllllll}\text { 5. Discussion } & \ldots & \ldots & \ldots & \ldots & \ldots & \ldots & \ldots & \ldots & \ldots & \ldots & 44\end{array}$

5.1. Part I: Interpretation of Stratigraphy, Calculation of Washover Volumes $\begin{array}{lllllllll}\text { and Sediment Fluxes } & \ldots & \ldots & \ldots & \ldots & \ldots & \ldots & \ldots & 44\end{array}$

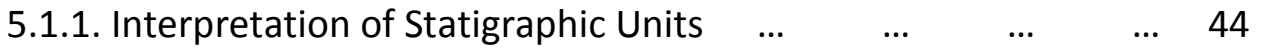

$\begin{array}{lllllllll}\text { 5.1.2. Washover Volumes } & \ldots & \ldots & \ldots & \ldots & \ldots & \ldots & 46\end{array}$

5.1.3. Dating the Washovers and Correlated Storms ... $\quad \ldots \quad \ldots \quad \ldots 0$ 
5.1.4. Recurrence Interval of Storm Water Levels $\quad \ldots \quad \ldots \quad \ldots \quad \ldots \quad 53$

$\begin{array}{lllllllll}\text { 5.1.5. Overwash Fluxes } & \ldots & \ldots & \ldots & \ldots & \ldots & \ldots & 54\end{array}$

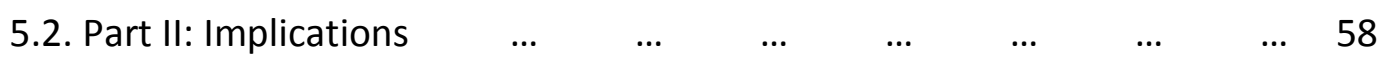

5.2.1. Comparison with Previous Work $\quad \ldots \quad \ldots \quad \ldots \quad \ldots \quad \ldots 8$

5.2.2. Estimating Washover Volumes from Aerial Photos $\quad \ldots \quad \ldots \quad 59$

5.2.3. Implications for Long-term Barrier Island Evolution $\quad \ldots \quad \ldots 63$

$\begin{array}{llllllllllll}6 . & \text { Conclusions } \ldots & \ldots & \ldots & \ldots & \ldots & \ldots & \ldots & \ldots & \ldots & \ldots & 65\end{array}$

$\begin{array}{llllllllllll}\text { 7. References } & \ldots & \ldots & \ldots & \ldots & \ldots & \ldots & \ldots & \ldots & \ldots & \ldots & 68\end{array}$

A. Appendix: Graphic core logs, radiographs, and verbal descriptions of $\begin{array}{llllllllllll}\text { sediment cores } & \ldots & \ldots & \ldots & \ldots & \ldots & \ldots & \ldots & \ldots & \ldots & 75\end{array}$

$\begin{array}{llllllllll}\text { A.1. Explanation } & \ldots & \ldots & \ldots & \ldots & \ldots & \ldots & \ldots & \ldots & 75\end{array}$

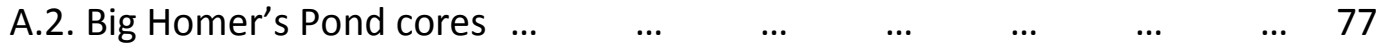

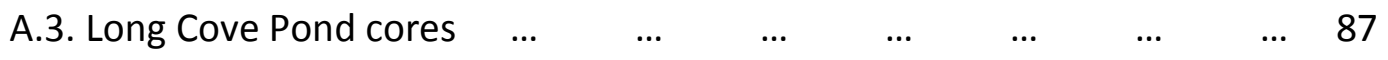

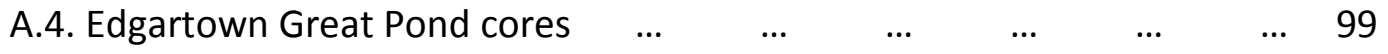

\section{Figures:}

Figure 1: Schematic of the various types of washovers described in text $\quad \ldots \quad \ldots \quad \ldots 11$

Figure 2: Location map of study area on Martha's Vineyard, MA $\quad \ldots \quad \ldots \quad \ldots \quad \ldots \quad 21$

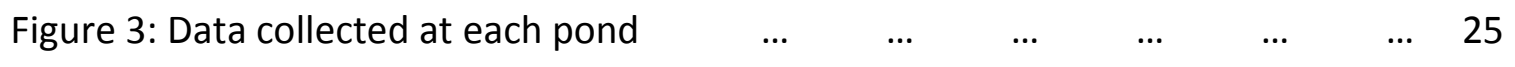

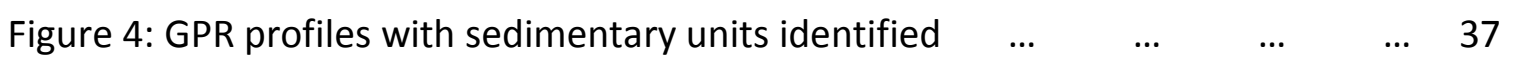

Figure 5: Stratigraphic section of five cores from Edgartown Great Pond $\quad \ldots \quad \ldots \quad 41$

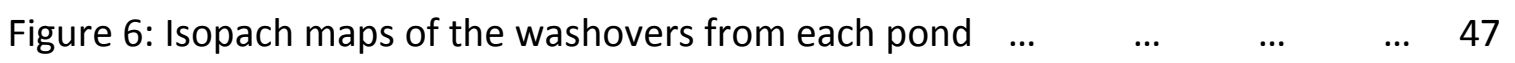

Figure 7: Aerial photos bracketing the deposition of the washovers $\quad \ldots \quad \ldots \quad \ldots 1$

Figure 8: Return intervals for water levels based on Woods Hole, MA tide

$\begin{array}{lllllllllll}\text { gauge data } & \ldots & \ldots & \ldots & \ldots & \ldots & \ldots & \ldots & \ldots & \ldots & 55\end{array}$ 
Figure 9: Schematic depicting the amount of onshore sediment flux required to maintain a stable barrier width during shoreline retreat and example

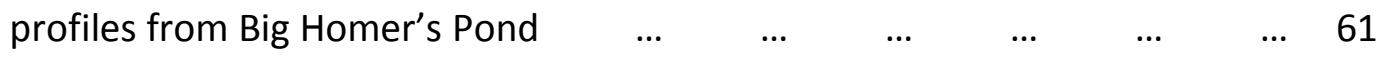

\section{Tables:}

Table 1: Previous estimates of washover volumes normalized per width of $\begin{array}{lllllllllll}\text { washover } & \ldots & \ldots & \ldots & \ldots & \ldots & \ldots & \ldots & \ldots & \ldots & 16\end{array}$

Table 2: Comparison of Big Homer's Pond, Long Cove Pond, and Edgartown Great Pond

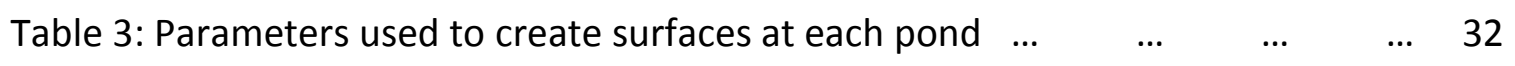

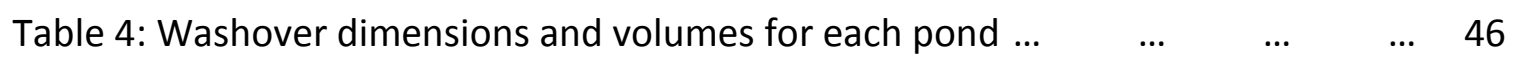

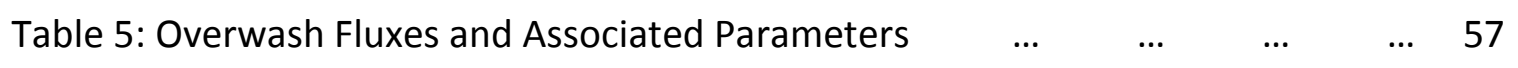

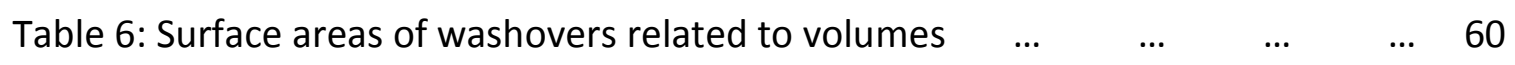

Table 7: Overwash fluxes needed for the barrier to maintain a stable shape $\quad \ldots \quad 65$ 


\section{Introduction}

Barriers form 10-13\% of the world's coastlines (Cromwell, 1971; Stutz and Pilkey, 2011), with 76\% occurring along rifted continental margins like that of the US Atlantic Coast which have wide depositional shelves, a wide flat coastal plain, and large supplies of available sediment (Inman and Nordstrum, 1971; Glaeser, 1978). Most barriers and barrier islands are located in areas that have undergone marine transgression, shift of the shoreline in the landward direction in response to a rise in relative sea-level (Davis, 1985). In order for barriers to retreat and be sustained during conditions of sea-level rise, sediment must be transported from the nearshore and foreshore of the barrier to the backbarrier (Fisher and Simpson, 1979). Mechanisms responsible for this landward sediment transport include tidal inlets, temporary inlets cut by storms, overwash of sand during storms, and aeolian transport (Boothroyd et al., 1985; Leatherman, 1985). The importance of overwash is increased as sea-level rise accelerates because transgressions typically lead to more frequent overwash events (Viles and Spencer, 1995). Different locations along the coast are influenced by unique combinations of sea-level rise rates, tidal range, storm tracks, wind and wave regimes, and sediment supply such that the dominant mechanism of barrier retreat is unique to each environment (Leatherman, 1985). On undeveloped coasts, overwash typically dominates, causing barriers to "roll over" (Dillon, 1970; Byrnes and Gingerich, 1987; Dolan and Godfrey, 1973; Schwartz, 1975). Here, it results from a combination of hurricanes and winter northeast storms (Donnelly et al., 2006). 
Numerous geometric models explore barrier transgressions. They are typically modifications and extensions of the Bruun (1962) rule that suggests that a waveaffected shoreline will recede, not simply passively flood, in response to sea level rise oversteepening the shoreface and causing sediment to migrate offshore. In this case, the shoreline retreats according to the slope of the shoreface. Coasts that have barriers respond to sea level rise in more complex ways. Applying equilibrium shoreface concepts to barriers results in the barrier transgressing faster than a shoreline without a barrier (Dean and Maurmeyer, 1983) with the ultimate path of the transgression following that of the backbarrier instead of the shoreface (Wolinsky and Murray, 2009). Other similar geometric models allow for this barrier evolution due to sea level rise to occur over geologic timescales (Cowell et al., 1995; Stolper et al., 2005).

Estimates of global sea-level rise by 2100 range from $75 \mathrm{~cm}$ to $190 \mathrm{~cm}$ over the time period of 1990 to 2100 (Vermeer and Rahmstorf, 2009) compared to $26 \pm 2 \mathrm{~cm}$ of sea level rise at Woods Hole, MA over the last 100 years (NOAA, 2011c). This estimate may be increased in New England by as much as $20-30 \%$ due to the complexities of the effect of the decreased gravitational pull of the large ice sheets, particularly Antarctic, if they melt rapidly (Mitrovica et al., 2009). Evidence is also mounting for an increase in the frequency of intense storms in the North Atlantic (Emanuel et al., 2008). In light of this, it is important to understand the amount of sediment that is transferred to the backbarrier by overwash under present conditions in order to predict how this flux may change in the future. This study uses sediment cores and high-resolution geophysical 
surveys to estimate the volume of sediment contained in selected washover fans to determine the onshore sediment flux caused by major storms. In calculating these fluxes, this study considers the three dimensional pre- and post- storm morphologies of the topographically low, southward-facing barriers of the southern coast of Martha's Vineyard, MA. These fans were deposited in historic times by storms of known magnitude and path in a regime of increased sea-level rise (Donnelly et al., 2004); therefore, they provide information on the possible effects on this shoreline given predictions of future storm climates. These fluxes also provide for an estimate of geometric barrier stability when compared with geometric models of modern barrier retreat.

\subsection{Overwash Processes and Deposits}

Overwash is the process by which large storm surge (defined as water level in excess of the predicted tide) and wave run-up (defined as the maximum vertical extent of wave up-rush on a beach) cause a flow of sediment-laden water to overtop a barrier, transporting sediment to the backbarrier. Washover refers to the deposit of sediment

landward of the beach caused by overwash (Schwartz, 1975). There are two endmember causes of overwash: run-up overwash and inundation overwash (Donnelly et al., 2006). Run-up overwash occurs when wave run-up causes the barrier to be overtopped and the resulting washovers are typically small and generally fan-shaped (the overwash regime of the Sallenger (2000) impact scale; figure 1; Donnelly et al., 


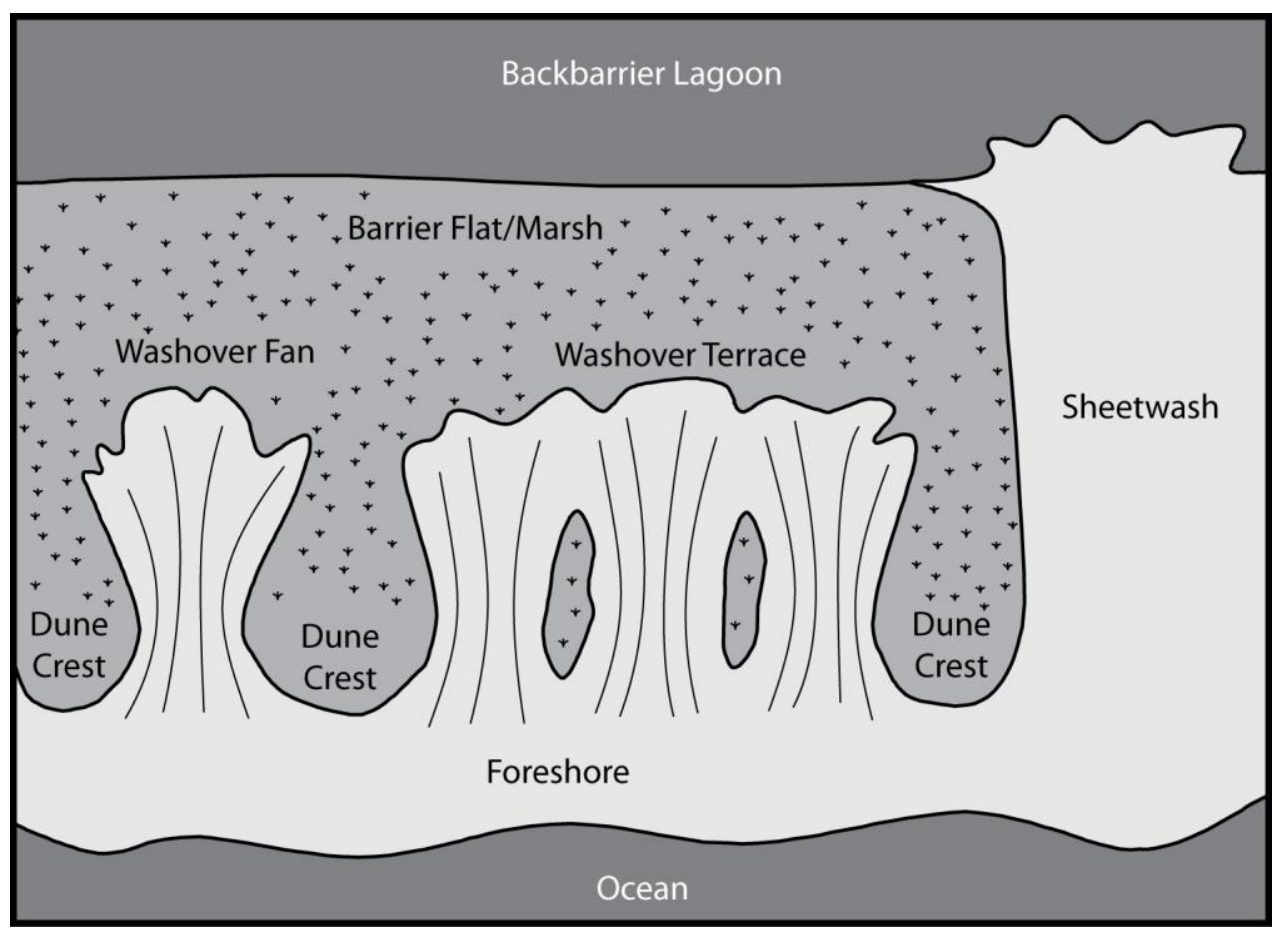

Figure 1: Schematic of various types of washovers described in text (after Donnelly et al., 2006). 
2006). When many small fans are deposited along a short stretch of barrier the landward portions may join forming a washover terrace (figure 1). Run-up overwash usually results from smaller storms than inundation overwash and usually happens in the hours surrounding high tide (Fisher and Stauble, 1977; Leatherman et al., 1977). Tidal inlets can also be formed by these same processes but typically occur where backbarrier slopes are steep and backbarrier tidal flats are small or absent (Pierce, 1970). Inundation overwash occurs when water levels rise over the top of the barrier causing the resulting washovers to be large sheets extending 100 s to 1000 s of meters wide (the inundation regime of the Sallenger (2000) impact scale; figure 1, Donnelly et al., 2006). Sheet overwash typically occurs when barriers are small and uniformly low (Orford et al., 2003) or when extreme storms cause unusually high surges (Fisher and Stauble, 1977). Overwash can result from a combination of run-up and inundation mechanisms and often exploits low areas such as relict washovers, dune blowouts, and anthropogenic paths (Fisher and Simpson, 1979). The low point, or throat (figure 1), acts to constrict the overwash flow and funnel it into the backbarrier where the flow expands and slows, causing sediment carried by the flow to be deposited into a fanshape. When this fan extends into a backbarrier lagoon or pond it is sometimes referred to as a washover delta (Leatherman 1976).

Overwash does not happen as a single episode of sediment overtopping the barrier, but as a succession of events potentially for the hours, or even days, that the storm and tide conditions cause sufficient wave energy and surge (Leatherman 1976). 
These multiple events of overwash cause laminations of the washover deposits (Schwartz 1975; Leatherman 1983), though these are not always seen in sediment cores (Leatherman et al., 1977; Boothroyd et al., 1985). The initial events of overwash can erode the throat and pre-overwash surface in the back barrier resulting in a reactivation surface (Pierce, 1970; Kochel and Dolan, 1986). This characteristic is readily observed in sediment cores if the washover extends into a backbarrier lagoon or pond as an abrupt contact between the washover sands and underlying mud (Donnelly et al., 2001a, b). This contact and the internal laminations of the washover can also be seen clearly using ground penetrating radar (GPR; Baker et al., 2007; Buynevich et al., 2004).

The size of the washovers is determined by the path and strength of the storm, particularly surge and wave amplitude (Liu and Fearn, 2000) with stronger storms passing close to a location producing much larger washovers than smaller storms passing farther away (Kochel and Dolan, 1986). The size and shape of the deposit is also controlled by backbarrier morphology and vegetation (Donnelly et al., 2006). Leatherman $(1976,1979 a)$ indicates that the volume of the washover is most dependent on storm surge height with the previously mentioned factors holding less importance. Morton and Sallenger (2003) note that washover volumes are related to the type of washover, increasing from confined fans, to terraces, to sheet overwash deposits. 


\subsection{Previous Studies of Washover Volumes}

Previous research on washover volumes has largely been conducted on barriers on the mid-Atlantic Coast, specifically on or near Assateague Island, MD (see table 1 for details). These studies have typically relied on a combination of sediment cores, aerial photos, and topographic profiles to estimate washover volume. Some use only average washover thicknesses, combined with inland washover penetration distances or washover area derived from aerial photos, to derive a volume of sediment (Morton and Sallenger, 2003). Others have used single or multiple pre- and post- overwash profiles multiplied by a unit width of barrier to arrive at washover volume estimates (e.g. Fisher and Stauble, 1977; Leatherman 1976, 1979a; Schwartz, 1975). These studies provide estimates of washover volume, but typically do not take into account the three dimensional variability of the pre- and post- storm topography (Morton and Sallenger, 2003). On the contrary, Kochel and Dolan (1986) used colored sediment plugs installed in a grid over the extent of older washovers to determine the thickness of the subsequent washovers in the same area in order to produce a contoured isopach map which accounted for spatially variable washover thickness. Another study that took the three-dimensional nature of the deposits into account when determining their volumes is that of Stockdon et al., 2007. That investigation subtracted pre-overwash from post- 
Table 1: Previous estimates of washover volumes normalized per width of washover. Intensities are given according to the Safar Simpson scale with TS=tropical storm; UR=unreported, *=landward penetration distance of washover is estimated,

**=data from a single fan, $\mathrm{CF}=$ confined flow. (Expanded from Morton and Sallenger, 2003)

\begin{tabular}{|c|c|c|c|c|c|c|c|}
\hline Washover Location & Storm & Intensity & $\begin{array}{l}\text { Surge } \\
(\mathrm{m})\end{array}$ & $\begin{array}{l}\text { Width } \\
\text { (m) }\end{array}$ & $\begin{array}{l}\text { Thickness } \\
(\mathrm{m})\end{array}$ & $\begin{array}{l}\text { Est. Vol. } \\
\left(\mathrm{m}^{3} / \mathrm{m}\right)\end{array}$ & Data Source \\
\hline Miami Beach, FL & Hurricane 1926 & 4 & 3.2 & 180 & 0.3 & $54^{*}$ & Reardon (1926) \\
\hline Long Island, NY & Hurricane 1938 & 3 & $\sim 3.6$ & $75-90$ & 0.9 & 70-80* & $\begin{array}{l}\text { Howard (1939), Redfield } \\
\text { and Miller (1957) }\end{array}$ \\
\hline Long Island, NY & Hurricane 1938 & 3 & $\sim 3.6$ & 60 & 0.9 & $\sim 54^{*}$ & $\begin{array}{l}\text { Wilby et al. (1939), } \\
\text { Redfield and Miller } \\
\text { (1957) }\end{array}$ \\
\hline Weekapaug Beach, RI & Hurricane 1938 & 3 & $\sim 3.6$ & 200 & 0.6 & 120* & $\begin{array}{l}\text { Nichols and Marston } \\
\text { (1929), Redfield and } \\
\text { Miller (1957) }\end{array}$ \\
\hline Charlestown Beach, RI & Hurricane 1938 & 3 & $\sim 3$ & 170 & 0.5 & $\sim 85^{*}$ & $\begin{array}{l}\text { Brown (1939), Redfield } \\
\text { and Miller (1957) }\end{array}$ \\
\hline Matunuck, RI & Hurricane 1939 & 3 & $\sim 3$ & 359 & 0.1 & $\sim 35$ & Donnelly et al. (2001a) \\
\hline Bolivar Peninsula, TX & Carla 1961 & 4 & 3 & 78 & 1.2 & 94 & $\begin{array}{l}\text { Morton and Sallenger } \\
\text { (2003) }\end{array}$ \\
\hline $\begin{array}{l}\text { Matagorda Peninsula, } \\
\text { TX }\end{array}$ & Carla 1961 & 4 & 4 & 750 & 0.25 & CF 225 & $\begin{array}{l}\text { Morton and Sallenger } \\
\text { (2003) }\end{array}$ \\
\hline Ocean City, MD & Northeaster 1962 & 5 & 2.1 & 110 & 1.5 & CF 165 & $\begin{array}{l}\text { U.S. Army Corps of } \\
\text { Engineers (1963) }\end{array}$ \\
\hline Core Banks, NC & Ginger 1971 & 1 & 1.2 & 100 & $0.1-0.3$ & $10-30$ & $\begin{array}{l}\text { Dolan and Godfrey } \\
\text { (1973), Simpson and } \\
\text { Hope (1971) }\end{array}$ \\
\hline Assateague Island, MD & Gilda 1973 & TS & UR & UR & UR & 5.5 & Fisher et al. (1974) \\
\hline Assateague Island, MD & Northeaster 1973 & UR & $\sim 1$ & UR & UR & 4.7 & Fisher et al. (1974) \\
\hline Outer Banks, NC & Northeaster 1973 & UR & UR & $\sim 113000$ & UR & $\sim 12$ & Schwartz (1975) \\
\hline Assateague Island, MD & Northeaster 1974 & UR & $\sim 1$ & 13 & UR & $20 * *$ & Leatherman et al. (1977) \\
\hline
\end{tabular}




\begin{tabular}{|llcccccc}
\hline Washover Location & \multicolumn{1}{c}{ Storm } & Intensity & $\begin{array}{c}\text { Surge } \\
(\mathbf{m})\end{array}$ & $\begin{array}{c}\text { Width } \\
(\mathbf{m})\end{array}$ & $\begin{array}{c}\text { Thickness } \\
(\mathbf{m})\end{array}$ & $\begin{array}{c}\text { Est. Vol. } \\
\left(\mathbf{m}^{3} / \mathbf{m}\right)\end{array}$ & Data Source \\
\hline Assateague Island, MD & Northeaster 1974 & UR & 0.8 & UR & UR & $28^{* *}$ & Leatherman (1976) \\
\hline Assateague Island, MD & Northeaster 1974 & UR & 0.8 & UR & UR & $14^{* *}$ & Leatherman (1976) \\
\hline Assateague Island, MD & Northeaster 1975 & UR & 1 & UR & UR & $2.7^{* *}$ & Leatherman (1976) \\
\hline Assateague Island, MD & Northeaster 1974 & UR & 0.8 & UR & UR & $8.5^{* *}$ & Leatherman (1976) \\
\hline Assateague Island, MD & Belle 1976 & 1 & 0.3 & UR & $\sim 0.5$ & $19^{* *}$ & Fisher and Stauble (1977) \\
\hline Cape Cod, MA & Northeaster 1978 & 1 & 1.2 & 125 & 1.2 & CF 150** & Leatherman and \\
\hline Nauset Spit, MA & Northeaster 1978 & 1 & UR & UR & 1.7 & CF 102 & Laremba (1987) \\
\hline Assateague Island, MD & Northeaster 1982 & UR & UR & $\sim 10-15$ & $0.08-0.16$ & $\sim 13-28$ & Kochel and Dolan (1986) \\
\hline Galveston Island, TX & Alicia 1983 & 3 & 3.8 & 30 & 0.7 & 21 & Morton and Paine (1985) \\
\hline Garden City, SC & Hugo 1989 & 4 & 3.6 & 70 & 0.5 & 35 & Nelson (1991) \\
\hline Debidue Beach, SC & Hugo 1989 & 4 & UR & UR & UR & $20-40$ & Eiser and Birkemeier \\
(1991)
\end{tabular}


overwash LiDAR topography data in order to arrive at a volume of sediment that was deposited over a large region that included a washover (Stockdon et al., 2007). The results of these studies are presented in table 1 . The normalized volume values are typically tens of $\mathrm{m}^{3} / \mathrm{m}$ while values greater than $100 \mathrm{~m}^{3} / \mathrm{m}$ are uncommon and associated with confined overwash flows where flow was constricted laterally by high topography or channelization.

\section{Study Area}

\subsection{Geologic Setting}

South Beach is a $25-\mathrm{km}$ long barrier located on the south-facing coast of Martha's Vineyard, a glacially-derived island located $\sim 8 \mathrm{~km}$ south of Cape Cod, Massachusetts, USA (Fig. 1). The island is composed almost entirely of large terminal moraines and glacial outwash deposited predominantly during the last (Wisconsinan) glaciation (Oldale, 1982). The Laurentide Ice Sheet reached its maximum extent $24-28$ ka (Balco et al., 2002; Stone and Borns, 1986) and by 23 ka the Martha's Vineyard Moraine was deposited and the ice sheet was retreating (Balco et al., 2002), retreating completely by 21 ka (Balco et al., 2009). Martha's Vineyard was formed at the intersection of two lobes of the Laurentide Ice Sheet: the Buzzard's Bay Lobe to the west and the Cape Cod Lobe to the east (Woodworth and Wigglesworth, 1934). The Martha's Vineyard Moraine that composes the northwestern and northeastern sides of the island (Oldale and Barlow, 1986) was deposited during local advances and stagnations of the 
lobes. This feature is morphostratigraphically equivalent to the Block Island and Ronkonkoma Moraines to the west (Oldale, 1982). A pre-Wisconsinan moraine (Gay Head Moraine) is expressed in patches on the western side of the island, and likely influenced the location of the local maximum extent of the Laurentide ice sheet lobes (Kaye, 1964a). A small expression of a third, older moraine (the Squibnocket Moraine) outcrops in one location in the southwest of the island (Oldale and Barlow, 1986). The only non-morainal or outwash topography on Martha's Vineyard is Gay Head. Located on the southwest corner of the island, this series of cliffs is composed of Cretaceous clay and some Miocene and other early Pleistocene sand and gravel beds that were folded and deformed during Pleistocene glaciations (Woodworth and Wigglesworth, 1934).

Central and southern Martha's Vineyard is composed of an expansive outwash plain that formed during local stagnation and retreat of the ice sheet lobes (Oldale, 1982). It is composed of stratified sand and gravel deposits and contains numerous long north-south trending ponds (Woodworth and Wigglesworth, 1934). These ponds were originally thought to be the drowned ends of meltwater channels that drained the ice sheet (Woodworth and Wigglesworth, 1934; Kaye, 1964b), but are considered now to be groundwater sapping channels (FitzGerald et al., 1993; Uchupi and Oldale, 1994) analogous to those described in similar environments in Maine by D'Amore (1983). This theory suggests that these channels formed by the piping of groundwater flow through the coarse sediment of the outwash plain in response to the high hydraulic head of Glacial Lake Cape Cod to the north. As sea level rose, channel valleys were flooded 
(FitzGerald et al., 1993). The barriers forming South Beach originally were thought to have formed offshore and migrated landward due to sea-level rise until they came in contact with the headlands of the drowned valleys (Woodworth and Wigglesworth, 1934). FitzGerald (1993) hypothesized that sediment eroded from the headlands between the bays would have provided material for the growth of spits across the mouths. Then, as sea-level rise continued, these barrier spits migrated onshore, reducing the bay tidal prisms until inlets could no longer be maintained, and the continuous expanse of South Beach developed. The small bay areas, low tidal range, and strong long-shore currents make inlets on South Beach unstable (FitzGerald et al., 1993) indicating that overwash processes must be the dominant mechanism for sediment to reach the backbarrier.

\subsection{Coastal Setting}

Modern South Beach is backed by one saline bay (Katama Bay), two large brackish ponds (Tisbury and Edgartown Great Ponds) and numerous small salt- and fresh- water ponds. Ephemeral inlets form at the openings to larger ponds to only occasionally disrupt the otherwise continuous South Beach. These inlets are generally formed in response to storms with the exception of an anthropogenic inlet on the eastern side of the barrier fronting Edgartown Great Pond. For 11 years between 1997 and 2008, this inlet was opened an average of 2.5 times per year and remained open for 


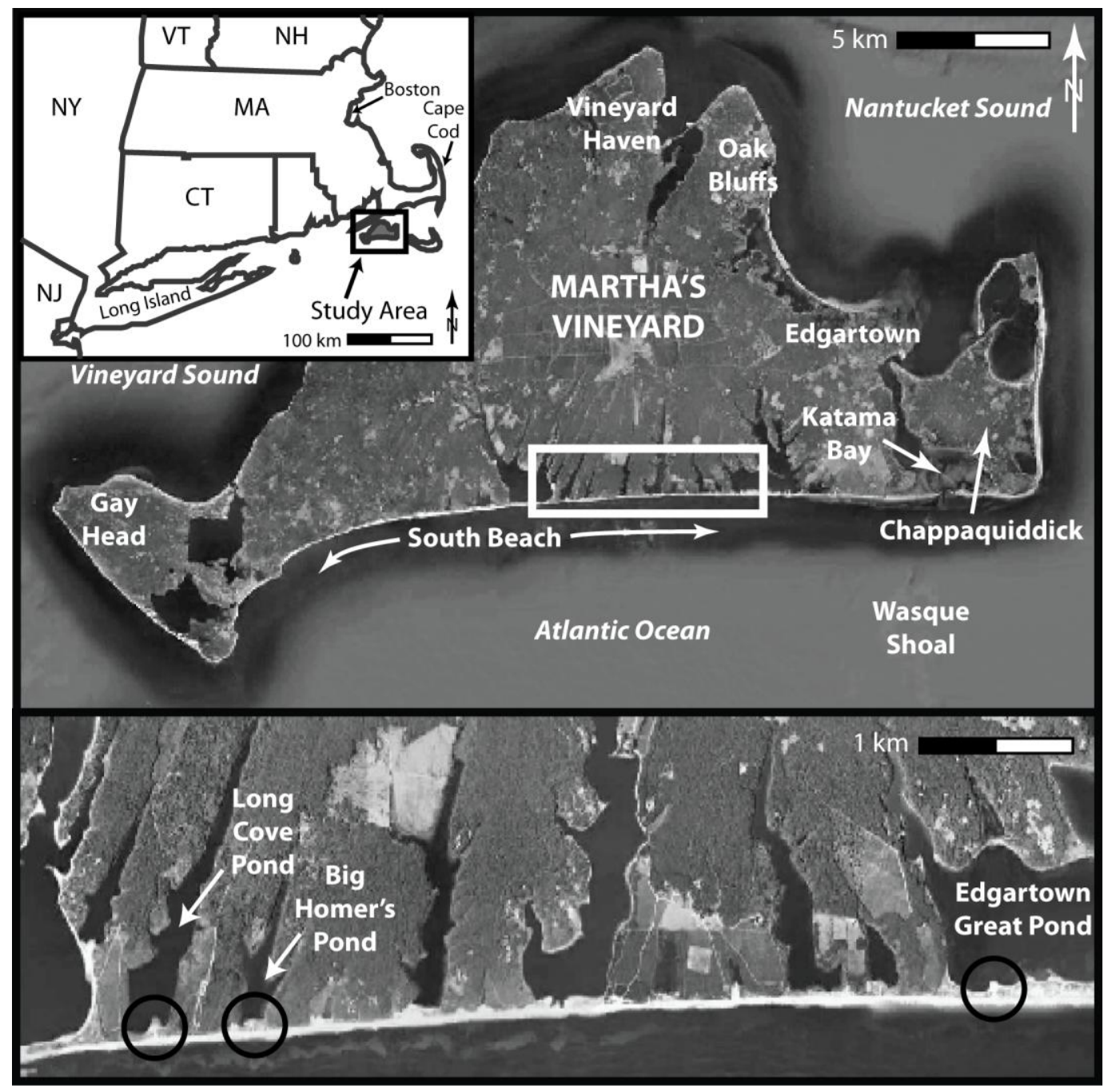

Figure 2: Location map of study area on Martha's Vineyard, MA. The location of the top figure is indicated by the black box in the inset. Bottom figure shows zoomed in area indicated by the white box in the top figure. The three ponds of interest are indicated in the bottom figure with the washovers at each pond indicated by the black circles. (Top figure modified from Google Earth $^{\mathrm{TM}}$, bottom figure modified from 2008 orthophotos from MassGIS.) 
an average of 12.5 days to allow for the maintenance of salinities and nutrient levels necessary to facilitate shellfish production in the pond (per. com. William Wilcox, 2011).

The south shore of Martha's Vineyard is a mixed energy, wave-dominated (Hayes, 1979), microtidal (mean tidal range: 0.6 m; NOAA, 2010) coast. The shoreface (extending to the barrier toe) dips at an angle of $\sim 1^{\circ}$ to a depth of $\sim 10 \mathrm{~m}$ (Cheung et al., 2007), then decreases to $\sim 0.1^{\circ}$ offshore to at least the $20 \mathrm{~m}$ contour. Waves are dominantly from the south which sets up an easterly long shore current on South Beach. Sediment eroded from South Beach is carried by this current and deposited southeast of Chappaquiddick to form Wasque Shoal and the ephemeral Skiff's Island (Ogden, 1974). As expected from the large amount of sediment deposited to form the shoal, South Beach has undergone high rates of erosion. Average rates for the south shores of Martha's Vineyard and Nantucket over the past two centuries are -1.4 m/yr (Hapke et al., 2010). Ogden (1974) found that the eastern portion of South Beach fronting Katama Bay and Chappaquiddick has retreated an average of $4.6 \mathrm{~m} / \mathrm{yr}$ since 1776 (similar to long term values of Hapke et al., 2010 at the same location). These high rates are likely due to the influence of the ephemeral inlet at Katama Bay that opens during major storms, allowing sediment to enter the bay during the shorter time scales when the inlet is open. The high rates of longshore sediment transport typically close this inlet in 10-15 years (Ogden, 1974). 
The south-facing orientation of South Beach provides for nearly unlimited fetch and a large susceptibility to hurricanes. Since 1848 there have been 88 tropical storms and hurricanes to pass within $150 \mathrm{~km}$ of Martha's Vineyard. Of these only 8 have been category 4 or higher, 53 were between categories 1 and 3, and 27 were tropical storms (Knapp et al., 2010). Strong northeast storms (nor'easters) also greatly impact New England, typically between October and April. Currently, 10-11 strong (winds in excess of $45 \mathrm{kts}$ ) nor'easters impact New England each winter (Frumhoff et al., 2007). It is both of these storm types that cause the overwash along South Beach. This study examines washover deposits located in three ponds backing South Beach: Big Homer's Pond, Long Cove Pond, and Edgartown Great Pond (figure 2). Comparisons of the three ponds of interest are presented in table 2.

Table 2: Comparison of Big Homer's Pond, Long Cove Pond, and Edgartown Great Pond

\begin{tabular}{|c|c|c|c|}
\hline & $\begin{array}{l}\text { Big Homer's } \\
\text { Pond }\end{array}$ & Long Cove Pond & $\begin{array}{c}\text { Edgartown Great } \\
\text { Pond }\end{array}$ \\
\hline Approx. Pond Area & $154,000 \mathrm{~m}^{2}$ & $320,000 \mathrm{~m}^{2}$ & $3,400,000 \mathrm{~m}^{2}$ \\
\hline Fronting Barrier Length & $220 \mathrm{~m}$ & $340 \mathrm{~m}$ & $2,400 \mathrm{~m}$ \\
\hline $\begin{array}{c}\text { Highest Elevation on } \\
\text { Barrier }\end{array}$ & $4.29 \mathrm{~m}$ & $5.06 \mathrm{~m}$ & $5.61 \mathrm{~m}^{(1)}$ \\
\hline $\begin{array}{c}\text { Lowest Elevation on } \\
\text { Barrier }\end{array}$ & $2.55 \mathrm{~m}$ & $1.66 \mathrm{~m}$ & $1.66 \mathrm{~m}^{(1)}$ \\
\hline Approx. Barrier Width ${ }^{(2)}$ & $75 \mathrm{~m}$ & $75 \mathrm{~m}$ & $105 \mathrm{~m}$ \\
\hline Maximum Pond Depth & $-2.7 m$ & $-3.5 m$ & $-5.0 m^{(3)}$ \\
\hline Number of Inlets & 0 & 0 & 1 (temporary) \\
\hline Anthropogenic Use & Some & Heavy & Some \\
\hline
\end{tabular}



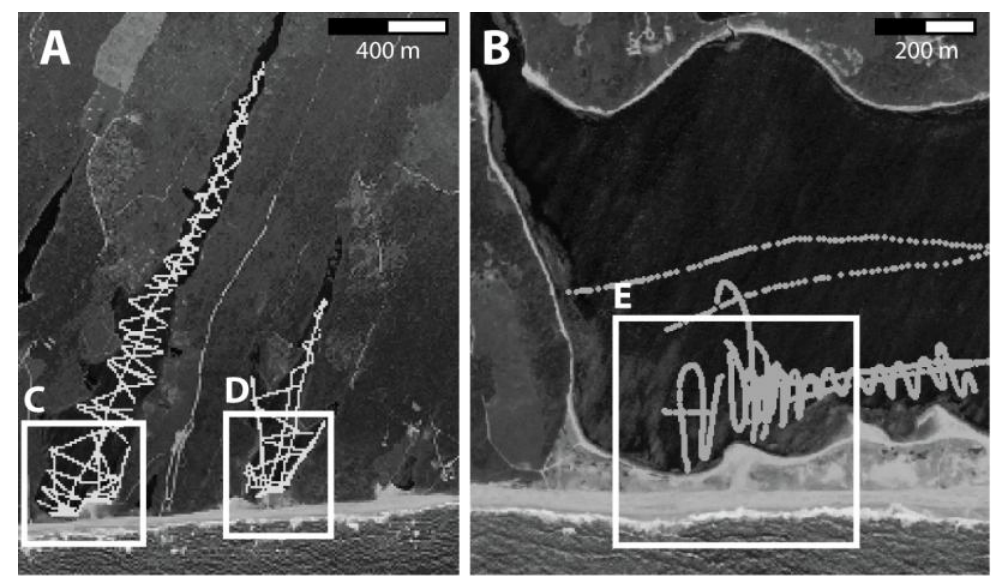

\begin{tabular}{|l|}
\hline \multicolumn{1}{c|}{ Explanation } \\
$\triangle$ Sediment Cores \\
$\sim$ GPR: collected through water column \\
$\sim$ GPR: collected on land \\
$\approx$ Shallow Seismic Data \\
dGPS: area of collection
\end{tabular}
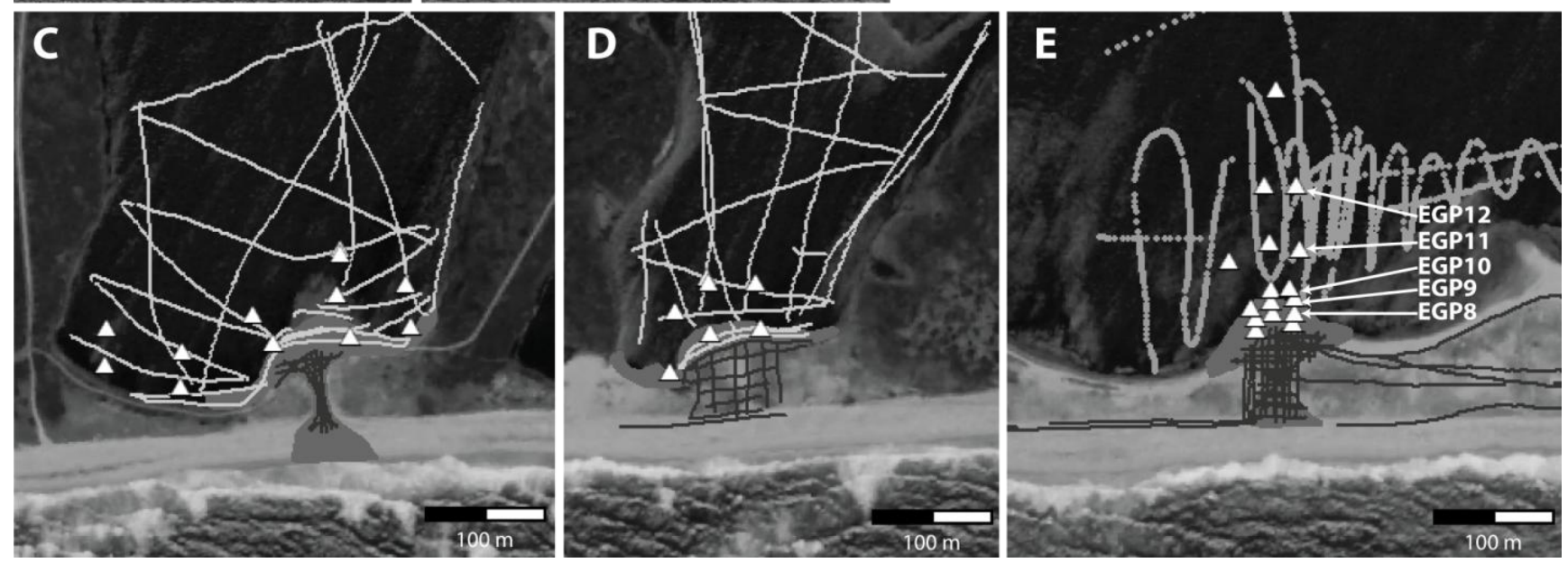

Figure 3: Data collected at each pond. Figure A depicts Long Cove Pond to the left and Big Homer's Pond to the right. Boxes indicate locations of figures $C$ and $D$. Figure $B$ depicts the washover at Edgartown Great Pond with a box to indicate the location of figure $E$. Figures C, D, and E show the dense data collected proximal to and on each washover at Long Cove, Big Homer's, and Edgartown Great Pond, respectively. Note that figures $C, D$, and $E$ all have the same scale. Cores labeled in figure $E$ are those included in transect in figure 5. (Images modified from 2008 orthophotos from MassGIS.) 


\section{Methods}

\subsection{Field Methods}

Three washover fans were identified on the south shore of Martha's Vineyard from aerial photographs. The field investigation of these fans consisted primarily of coring, use of ground penetrating radar (GPR), and use of a differential global positioning system (dGPS; figure 3). Most field work was conducted in early August of 2009, with return trips to extend spatial coverage of data in July and September of 2010.

A total of 35 vibracores were collected in each pond in a radiating grid pattern. Due to the sandy nature of the subsurface, the cores were fairly short, ranging from 39 to $301 \mathrm{~cm}$ with an average core length of about $130 \mathrm{~cm}$. All the cores were taken using a standard vibracore system from a raft floating on the ponds.

GPR was taken on the subaerial portion of each fan using a Malå Geoscience 250 $\mathrm{MHz}$ antenna, with some lines taken with 500 and $800 \mathrm{MHz}$ antennae at Edgartown Great Pond. GPR was also collected with the $250 \mathrm{MHZ}$ antenna floating on an inflatable raft on Big Homer's Pond and Long Cove Pond. All GPR data taken on land was distancetriggered with a wheel, while that taken in the ponds was time-triggered. A total of almost 5,000 m of GPR was taken on land at Edgartown Great Pond, over $600 \mathrm{~m}$ at Long Cove Pond, and over 900 m at Big Homer's Pond. Over 11,000 m of GPR was taken through the water column at Long Cove Pond and over 5000 m was taken at Big Homer's Pond. This technique provided excellent bathymetry throughout the two 
ponds, as well as sub-bottom structure in shallow water. Unfortunately, this method was not possible in Edgartown Great Pond due to its comparatively high salt water concentration, which increases the electrical conductivity of the water and, in turn, attenuates the high frequency electromagnetic signal of the radar. Penetration was also poor on the subaerial portion of the fan, likely due to the salt water table. Instead, bathymetry at Edgartown Great Pond was determined acoustically using over 3,000 m of seismic data collected using a $10 \mathrm{KHz}$ SyQuest StrataBox and some internal structure of the fan was revealed by the excavation of a $\sim 20 \mathrm{~m}$ long, up to $\sim 1 \mathrm{~m}$ deep trench.

Modern surface morphologies of the fans were determined by taking dGPS surveys using a Trimble ProXRT with real time corrections from OmniSTAR. The surveys had maximum vertical errors of between 10 and $30 \mathrm{~cm}$ and lateral positioning errors on the order of $10 \mathrm{~cm}$. The surveys were taken on the subaerial portions of the fan as well as in the water, to bridge the data gap between the bathymetry provided by the GPR and Stratabox data and the topography available with LiDAR (JALBTCX, 2009). Almost 3,000 dGPS points were collected at Edgartown Great Pond, close to 4,000 points at Long Cove Pond, and almost 2,000 points at Big Homer's Pond.

\subsection{Laboratory Methods}

All of the sediment cores have been visually described for macro structure, color, and grain size. Color descriptions were made using Munsell color standards (Munsell, 
2000) and bulk grain size was determined by comparing samples with known standards at $10 x$ magnification.

All cores were scanned using an ITRAX XRF core scanner for radiographic images with 200 micron step sizes. XRF scans of select cores with high mud content were also taken as these cores had the potential to capture the industrial lead peak, thereby providing an age horizon within the core.

\subsection{Data Processing}

GPR data were processed using DECO-Geophysical Ltd.'s RadExplorer software package. Processing typically included DC removal (often called "dewowing," removes the low-frequency signal trend from the initial DC signal component), time-zero adjustment (adjusting the zero depth to the first return instead of the direct wave), background removal (averages all traces in a section and subtracts it from each trace to remove background noise), 2D spatial filtering (filters data both temporally down trace and spatially across a number of traces), predictive deconvolution (filtering data temporally by improving resolution by compressing wavelets into narrow, distinct forms), amplitude correction using automatic gain control (equalizing signal amplitudes down each trace), band pass filtering (removing high and low frequency noise), Stolt F-K migration (a migration in the time domain using a bulk sediment velocity where diffracted energy is collapsed back onto its point-source location in the case of hyperbolas and the true dip angles of sloping reflectors is restored), and topographic 
correction (correcting the vertical position of a trace to the elevation of the ground surface, instead of a flat plane). The topographic corrections were performed using LiDAR data or dGPS data, depending on data quality. Time varying velocity models were constructed for data collected in the ponds with a velocity of $3.33 \mathrm{~cm} / \mathrm{ns}$ used for the water and $6.0 \mathrm{~cm} / \mathrm{ns}$ used for the sediment. This velocity was used for all of the sediment as it was typically that indicated by hyperbolic velocity analysis, whereby a reflection hyperbola in a GPR profile is fitted with the ideal form of a velocity-specific form. Hyperbolas occur when a scattering source is buried in sediment of uniform velocity. As an antenna moves closer to and then away from the scattering source the received signal produces a hyperbolic shape dependent on the velocity of the sediment. It is this shape that can be fitted with idealized hyperbolas to give an approximate sediment velocity. Hyperbolas occurred infrequently in the data, so this bulk velocity was used for all saturated sediment. Reflectors corresponding with surfaces of interest were picked in RadExplorer using a combination of manual auto-fill parameters where picks were filled in at every trace for short distances between manually picked point along either troughs or peaks.

The Stratabox data was post-processed using Triton Imaging, Inc.'s SBInterpreter software. Processing included similar procedures as were used with GPR data including flat and time-varying gain adjustment, bandpass filtering, and vertical downsampling. The sediment-water interface was picked manually. The dGPS data was post processed using Trimble's GPS Pathfinder Office software. The data were not 
differentially corrected at this time, as they had already been corrected in real time. Instead, this software allowed the raw data to be converted from proprietary Trimble formats to both ASCII and ArcGIS shapefile formats (.shp).

After post processing was complete, 3D locations and other spatially varying information (e.g. GPR trace numbers, dGPS accuracy) of all data were spatially analyzed in ArcMap. The geospatial reference frame of all the data collected was set to the Universal Transverse Mercator (UTM) coordinate system with the WGS84 ellipsoid, using Data East's XToolsPro extension for ArcMap. Standard offsets between the different vertical datums (pond surface, dGPS, and LiDAR) were determined by comparing as many overlapping points as possible (typically 15 to 50 ) and all data was vertically referenced to the water level in each pond.

\subsection{Three Dimensional Surface Calculations}

Two surfaces were created using universal kriging for each pond: a modern surface and a pre-overwash surface. Surfaces were kriged using Golden Software's Surfer8 program. Kriging uses trends in unevenly spaced (non-gridded) three dimensional data in order to extrapolate into areas of no data and to create a regularly gridded surface. The modern surfaces were kriged with data from GPR (Stratabox at Edgartown Great Pond), LiDAR, dGPS, and pond outlines taken from orthophotos in ArcMap. Pre-overwash surfaces were kriged with data from cores, GPR whenever 
possible, and a zero accumulation contour on all but the southern sides of the pond taken to be the location of the pond edge.

Table 3: Parameters used to create surfaces at each pond. "Modern" refers to the modern surface and "paleo" refers to the pre-overwash surface. The scale, or sill, is the height on the y-axis where the variogram levels off. The length, or correlation length, is the lag distance when the scale is reached. The nugget refers to the $y$-intercept. Anisotropy is geometric anisotropy that occurs when the experimental variogram has different lengths in different directions.

\begin{tabular}{|c|c|c|c|c|c|c|}
\hline & \multicolumn{2}{|c|}{ Big Homer's Pond } & \multicolumn{2}{|c|}{ Long Cove Pond } & \multicolumn{2}{|c|}{ Edgartown Great Pond } \\
\hline & Modern & Paleo & Modern & Paleo & Modern & Paleo \\
\hline Data Points & 55286 & 3395 & 103485 & 5602 & 4432 & 207 \\
\hline $\begin{array}{c}\text { Model } \\
\text { Variogram } \\
\text { Type }\end{array}$ & Gaussian & Gaussian & Gaussian & Linear & Gaussian & Linear \\
\hline $\begin{array}{l}\text { Scale (or slope } \\
\text { if linear) }\end{array}$ & $0.65 \mathrm{~m}^{2}$ & $4.08 \mathrm{~m}^{2}$ & $0.80 \mathrm{~m}^{2}$ & $0.006 \mathrm{~m}^{2}$ & $6.05 \mathrm{~m}^{2}$ & $0.0004 \mathrm{~m}^{2}$ \\
\hline Length & $28 \mathrm{~m}$ & $321 \mathrm{~m}$ & $95 \mathrm{~m}$ & $\mathrm{~N} / \mathrm{A}$ & $350 \mathrm{~m}$ & N/A \\
\hline Nugget Effect & $0 \mathrm{~m}^{2}$ & $0.73 \mathrm{~m}^{2}$ & $0.02 \mathrm{~m}^{2}$ & $0.19 \mathrm{~m}^{2}$ & $0.043 \mathrm{~m}^{2}$ & $0.001 \mathrm{~m}^{2}$ \\
\hline $\begin{array}{l}\text { Anisotropy } \\
\text { Ratio }\end{array}$ & 1.0 & 2.0 & 1.9 & 2.0 & 2.0 & 2.0 \\
\hline $\begin{array}{c}\text { Anisotropy } \\
\text { Angle }\end{array}$ & $0^{\circ}$ & $13.4^{\circ}$ & $30.0^{\circ}$ & $99.7^{\circ}$ & $0^{\circ}$ & $82.1^{\circ}$ \\
\hline $\begin{array}{l}\text { Kriging Search } \\
\text { Radius }\end{array}$ & $100 \mathrm{~m}$ & $120 \mathrm{~m}$ & $75 \mathrm{~m}$ & $170 \mathrm{~m}$ & $400 \mathrm{~m}$ & $N / A^{*}$ \\
\hline $\begin{array}{l}\text { Kriging Search } \\
\text { Angle }\end{array}$ & $0^{\circ}$ & $0^{\circ}$ & $30^{\circ}$ & $-10^{\circ}$ & $15^{\circ}$ & $N / A^{*}$ \\
\hline Grid Spacing & $8 \mathrm{~m}$ & $8 \mathrm{~m}$ & $7 \mathrm{~m}$ & $7 \mathrm{~m}$ & $8 \mathrm{~m}$ & $8 \mathrm{~m}$ \\
\hline
\end{tabular}

*small data set so all points were used

Before kriging, variogram analysis was performed on all data for each surface. A variogram characterizes the spatial continuity or roughness of a data set. The analysis 
consists of first calculating the experimental variogram from the data by averaging half of the difference squared of the elevation values over all pairs of observations at each specific distance and direction over the entire range of lag values (with the maximum lag being the maximum distance of separation to be considered, or about one third the diagonal extent of the observed values). Next, the model variogram is fitted to the experiment variogram using combinations of known functions. The model variograms here were typically an anisotropic Gaussian variogram model with a small nugget. Table 3 provides variogram model fit parameters and some kriging parameters for each surface.

Following the kriging of the modern surfaces, the results were analyzed in ArcMap so data for the pre-overwash surface (particularly GPR) could be referenced to the modern surface. After their calculations, the pre-overwash surfaces were subtracted from the modern surfaces to create isopach maps of the washovers. All negative points were discarded from these maps as they are meaningless and beyond the range of the washover deposits. Ideally, beyond the extent of the washover the pre-overwash and modern surfaces would be the same. Unfortunately, due to limited sediment core data coverage, the furthest landward extent of the washovers is not captured in the data and is thus unknown. This is why the pre-overwash data includes a zero accumulation contour at the pond edge as it is assumed that the washover did not extend past the edges of the pond. In actuality it is not likely to extend nearly that far, but it is impossible to estimate this actual extent. Consequently, the zero accumulation contour 
causes the pre-overwash surface to rise above the elevation of the modern surface past the extent of the washover because of the lack of data between the two regions (the washover and the zero accumulation contour). This difference results in the negative points in the isopach map that mark the edge of the washover and are thus discarded. The volume under the resulting map is then be determined by numerical integration, of which Surfer offers a variety of methods (Trapezoid Rule, Simpson's Rule, and Simpson's 3/8 Rule). Using all three methods gives an estimate of the error in the calculation, with all methods giving results that are comparable to two significant figures for these data.

\subsection{Flux Calculations}

Overwash flux was estimated by first establishing the storm that most likely produced each deposit. Aerial photos were used to narrow the time interval over which the overwash even occurred. Hurricane records (specifically The Best Track Reanalysis Data from the National Oceanic and Atmospheric Administration's (NOAA) National Hurricane Center; Landsea et al., 2004; Neumann et al., 1993) and monthly maximum water levels from two nearby tide gauges (Newport, RI and Woods Hole, MA; NOAA, $2011 a, b)$ were used to identify the storm that produced the maximum surge at the location of the fan during that time. Surge from hurricanes was estimated using the Sea, Lake and Overland Surges from Hurricanes numerical model (SLOSH; Jelesnianski et al., 1992). The recurrence interval of storm that produced at least the same water level from the storms that caused the overwash was determined using the monthly extreme 
tide gauge data from Woods Hole, MA from 1932 to present (NOAA station ID 8447930; NOAA, 2011b). The monthly nature of the tide gauge data means that only the highest water level is recorded each month, so lower water levels are likely underestimated. As the higher water levels are of interest to this study this error should not greatly affect the return intervals used here.

The washover volumes are normalized by dividing the volume by the width of the effected barrier (units of $\mathrm{m}^{3} / \mathrm{m}$ ). The affected width is defined as either the width of the barrier fronting the pond containing the washover, if there are no other washovers in the pond, or the distance half way between washovers, if there are multiple washovers in the pond. The overwash flux (units of $\mathrm{m}^{3} / \mathrm{m} / \mathrm{yr}$ ) can then be estimated by dividing the normalized volume by the surge recurrence interval. The range in recurrence intervals leads to a range of potential fluxes resulting in this estimation giving an order of magnitude estimate of the onshore sediment flux caused by overwash.

\section{Results}

\subsection{Big Homer's Pond}

Ground-penetrating radar collected at Big Homer's Pond show a weak signal until the sediment/water interface which is identified by a very strong reflector. Due to the nature of GPR collected through the water column, the sediment/water interface often produces at least one strong multiple in the radargram (figure $4 A$ ). In most 
locations, the radar signal is attenuated quickly beyond the sediment/water interface, such that deeper reflectors are rarely visible. In contrast, GPR signals in the profiles collected both in shallow water (proximal to the fan) and terrestrially are able to penetrate to a maximum of about $\sim 8$ meters, depending on the frequency of the antenna used.

GPR data were supplemented with seven vibracores, ranging from 60 to $260 \mathrm{~cm}$ in length. The combination of radar and sediment core data allows us to define a series of four sedimentologic units (figure 4,5 ). Unit A is recognized in four cores as layers of coarse sand (51-224 cm thick) interbedded with either muddy units (3-9 cm thick) or occasional peat $(12 \mathrm{~cm})$. One to five beds are present. This unit is not visible in GPR profiles due to signal attenuation. Unit B is present in five cores and ranges in thickness from $29-103 \mathrm{~cm}$. It is composed of massive, very dark gray (2.5Y 3/1; Munsell, 2000) silty clay with occasional flecks of decomposing organics. The GPR signal attenuates quickly in Unit B, a characteristic common to muddy environments due to the high conductivity of clay (Baker et al., 2007). Although little structure is evident in this GPR unit, any visible internal reflectors are generally horizontal. This unit typically has a sharp upper contact with Unit $\mathrm{C}$ in the cores, which is seen as a very strong reflector in the GPR profiles (figure 4B, C). Unit C is composed of an olive brown (2.5Y 4/4), poorly sorted, coarse to very coarse sand. This unit is generally massive, contains few heavy minerals, and varies from 14 to $>126 \mathrm{~cm}$ in the cores, thickening southward toward the barrier to reach a maximum of $\sim 450 \mathrm{~cm}$ thick in the radar sections. In lines collected 

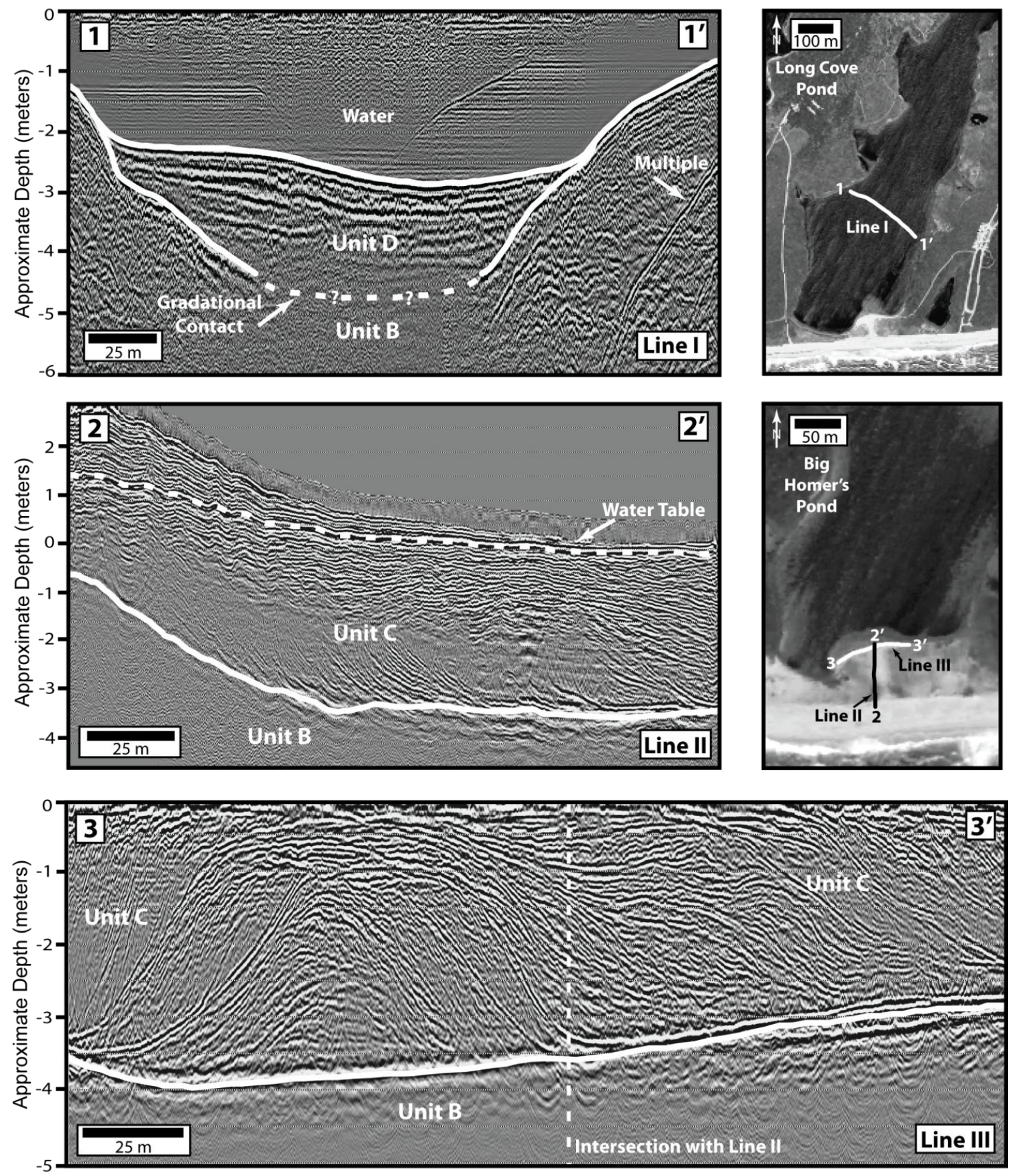

Figure 4: GPR profiles with sedimentary units identified. Vertical scale is referenced to each pond's still water level. Top left: radargram from Long Cove Pond (location of line is indicated top right) taken through the water column. Center left is a radargram from Big Homer's Pond taken on land and topographically corrected. Location of line is given center right. Bottom is a radargram from Big Homer's Pond taken on land and topographically corrected (profile is flat). Location of line is given center right. 
along north-to-south, shore-normal profiles, Unit C contains internal reflectors that dip northward, into the pond (figure 4B). These clinoforms shoal toward the top of the unit from $5-10^{\circ}$ near the bottom, to $1-5^{\circ}$, to top reflectors nearly horizontal at $<1^{\circ}$. Internal reflectors in this unit in profiles collected along east/west, shore-parallel lines have an approximately Gaussian-like shape (figure $4 \mathrm{C})$ : they are nearly horizontal $\left(<1^{\circ}\right)$ at the center and then dip to both sides at $5-15^{\circ}$ before becoming nearly horizontal distal to the center of the structure. Though not distinguishable from the top of Unit C in GPR, two of the cores are topped by a thin $(1-2 \mathrm{~cm})$ Unit D of very dark grayish brown $(2.5 Y 3 / 2)$ saturated mud.

\subsection{Long Cove Pond}

Twelve vibracores were collected at Long Cove pond ranging in length from 39$301 \mathrm{~cm}$. Radargrams showed the same signal attenuation through the water column as at Big Homer's Pond with maximum penetration to about eight meters for data taken on land or in shallow water proximal to the fan.

Lithologic units described for Big Homer's Pond were also identified at Long Cove Pond. Unit A was seen in eight of the cores. Cores contain 1-18 beds in this unit, with $0.5-114-\mathrm{cm}$ thick sand beds, $3-113-\mathrm{cm}$ thick mud beds, and one instance each of solitary beds of mixed shell hash (19 cm thick) and peat $(4.5 \mathrm{~cm}$ thick). Unit B is identified clearly in four cores. It is a massive very dark brown (10YR2/2) silty clay, 1 to $>56 \mathrm{~cm}$ thick. When visible in radargrams, Unit B contains horizontal reflectors, though 
there is little signal penetration into the unit (figure 4). The boundary between units B and $\mathrm{C}$ is typically seen as a sharp contact in cores and as a very strong reflector in GPR profiles. Seven cores contain the massive olive brown (2.5Y4/3) coarse sand typical of Unit C. This unit is 3 to $>107 \mathrm{~cm}$ thick, increasing toward the south. Radargrams indicate that Unit $C$ reaches a maximum depth of $\sim 450 \mathrm{~cm}$ at the southern edge of the fan. In shore-normal GPR profiles, this unit is observed as a series of clinoforms dipping northward into the pond at $\sim 5-15^{\circ}$. As at Big Homer's Pond, the reflectors shoal toward the top of the unit to nearly horizontal $\left(<1^{\circ}\right)$ at the top. Shore-parallel radargrams show an asymmetry in the thickness of the unit, with the thickest regions on the western side of the fan. The internal structure is seen again as reflectors with Gaussian-like shapes, though the shape demonstrates a marked easterly skewness with much steeper maximum dip angles on the western side $\left(\sim 20^{\circ}\right)$ than on the eastern side $\left(\sim 4^{\circ}\right)$. Internal reflectors are more chaotic than at Big Homer's Pond. In three of the cores, Unit $\mathrm{C}$ is overlain by the very dark grayish brown (2.5Y3/2) saturated mud of unit $D$, ranging from a thin lens $(<0.5 \mathrm{~cm})$ to $3 \mathrm{~cm}$ thick. In four cores, unit $C$ is not present and Unit B grades directly to unit $D$. The combined thickness of units $D$ and $B$ in these cores are $2-18 \mathrm{~cm}$.

\subsection{Edgartown Great Pond}

Sixteen vibracores were collected at Edgartown Great Pond, ranging from 48$158 \mathrm{~cm}$ in length. In contrast to the other two ponds, these cores provide the most 


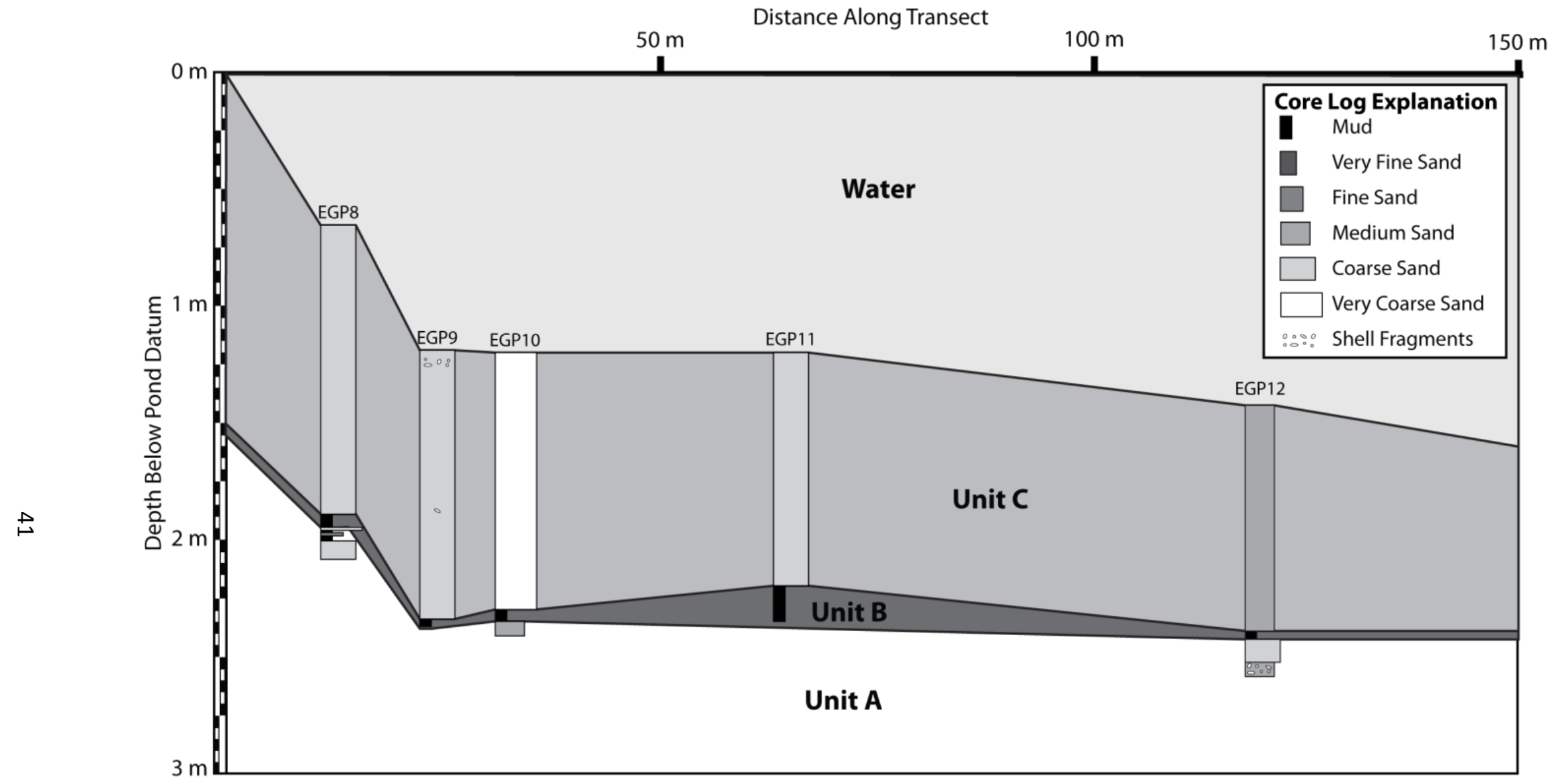

Figure 5: Stratigraphic section of five cores from Edgartown Great Pond showing Units A though C. Cores used in the profile are labeled in figure 3. The distance along transect goes from south $(0 \mathrm{~m})$ to north $(150 \mathrm{~m})$. 
insightful of the stratigraphic information. Higher salinities in this brackish pond result in rapid GPR signal attenuation below the water table. Maximum penetration is therefore only $150 \mathrm{~cm}$, and typically less than $100 \mathrm{~cm}$. A shore-normal trench provided some insight into the top $70 \mathrm{~cm}$ of the subaerial portion of the fan. Shallow seismic reflection profiles were used to map pond bathymetry. However, shallow multiples and a low signal to noise ratio prevented interpretation of sub bottom data.

Similar stratigraphic units described at Big Homer's and Long Cove Ponds were also observed at Edgartown Great Pond (figure 5). Unit A is identified in seven cores with $1-5$ beds present containing sand layers ranging from $1.5-122 \mathrm{~cm}$ thick with occasional mixed shell hash and mud layers ranging from $1-8 \mathrm{~cm}$ thick. Eight cores contain the dark olive brown (2.5Y3/3) silty mud common to Unit B. These layers are 2 to $>15.5 \mathrm{~cm}$ thick. One core contained shell hash mixed into this unit. The contact between Units B and C is again sharp. Unit $\mathrm{C}$ is identified in 15 cores as a coarse to very coarse, light olive brown (2.5Y5/3) sand, 93-124 cm thick. Several cores contained shell fragments and pebbles in this unit. Unit C is identified in GPR profiles as a series of shallowly $\left(<2^{\circ}\right)$ northward dipping clinoforms. The bottom contact between Units B and $\mathrm{C}$ is not seen in the radargrams and only the top of Unit $\mathrm{C}$ is captured due to signal attenuation. The trench displays similar shallowly-northward dipping layers corresponding to radar reflectors. Only two cores contain the olive gray $(5 Y 4 / 2)$ mud of Unit $\mathrm{D}$, in one of these Unit $\mathrm{C}$ is absent so Unit $\mathrm{B}$ grades directly into Units $\mathrm{D}$. Here, these two units have a combined thickness of $11 \mathrm{~cm}$. 


\section{Discussion}

\subsection{Part I: Interpretation of Stratigraphy, Calculation of Washover Volumes and Sediment Fluxes}

Sediment cores and high-resolution geophysical surveys allow for the estimation of the volume of sediment contained in selected washover fans in order to determine the onshore sediment flux caused by major storms. In calculating these volumes, this study considers the three dimensional pre- and post- storm morphologies of the topographically low, southward-facing barriers of the southern coast of Martha's Vineyard, MA. These fans were deposited in historic times by known storms; accordingly, the recurrence intervals of the surges produced by the storms that caused the deposits can be estimated. These recurrence interval estimates allow for a firstorder estimate of the onshore flux of sediment from these overwash events to be calculated.

\subsubsection{Interpretation of Statigraphic Units}

Stratigraphies interpreted from cores and radar data (figure 5) are similar across the ponds and are therefore interpreted to have resulted from the same processes. Unit $A$ is interpreted to be sand deposited during earlier overwash events, interbedded with mud deposited in a quiescent lacustrine environment. Unit B represents mud deposited in the pond immediately prior to the deposition of the massive sands of Unit C. The sharp contact seen in cores and the strong reflector truncating underlying weak 
reflectors seen in radargrams likely indicates a strongly erosional upper boundary created during the deposition of the overlying sediment. Unit C contains the sand of the subaerial washover deposit. The presence of clinoforms within the unit suggests that it was first deposited in a small fan or tongue during the early stages of the overwash event. This fan then built laterally and vertically during the course of the overwash event, until a fan shape had developed. The steep reflectors near the bottom of the unit show the delta-like structure of the fan due to its deposition in standing water. The deposit thins distal to and along the barrier due to dissipation of wave energy that causes most sediment to be deposited closer to the throat of the washover. Clinoforms in this unit at Long Cove pond were more chaotic than at the other ponds, likely due to the extensive anthropogenic modification of this site from recreational activities. The shallowing of internal clinoforms toward the very top of Unit C is likely due to aeolian reworking of the upper subaerial portion of the fan with the shallower reflectors toward the top of the unit likely similar to delta-topsets. The thin sediment of Unit D is the modern pond mud. Cores in which Unit B grades directly to Unit D are beyond the extent of the washover and have therefore not captured Unit C. Many cores at Edgartown Great Pond contained shells or shell hash. This is likely due to the numerous shell fish beds in this brackish pond which are absent at the other two freshwater ponds. 


\subsubsection{Washover Volumes}

A few assumptions allow for the estimation of washover volumes from the detailed stratigraphic analyses at each of the three sites. First, the lower boundary of the deposit is taken to be the erosive contact between Units B (lacustrine mud) and C (washover sand). This surface is likely topographically lower than the actual preoverwash surface most likely due to scouring of the barrier and backbarrier pond during the initiation of the overwash event. Second, the portion of the washover that contributes to the landward migration of the barrier is taken as only that which is deposited landward of the pre-overwash barrier. This boundary is taken to be the vertical plane created by the vegetation line on either side of the washover.

Table 4: Washover dimensions and volumes for each pond

\begin{tabular}{ccccc}
\hline Pond & $\begin{array}{c}\text { Volume } \\
\left(\mathbf{1 0}^{\mathbf{4}} \mathbf{m}^{\mathbf{3}}\right)\end{array}$ & $\begin{array}{c}\text { 2D Surface } \\
\text { Area }\left(\mathbf{1 0}^{\mathbf{4}} \mathbf{m}^{\mathbf{2}}\right)\end{array}$ & $\begin{array}{c}\text { Maximum } \\
\text { Thickness }(\mathbf{m})\end{array}$ & $\begin{array}{c}\text { Average } \\
\text { Thickness }(\mathbf{m})\end{array}$ \\
\hline Big Homer's Pond & 2.1 & 1.5 & 4.5 & 1.4 \\
Long Cove Pond & 2.3 & 1.4 & 4.4 & 1.6 \\
Edgartown Great Pond & 2.4 & 2.5 & 2.5 & 1.0 \\
\hline
\end{tabular}

Isopach maps were created for the washovers in each of the three ponds (figure 6) by digitally subtracting the surface created for the lacustrine mud/washover 


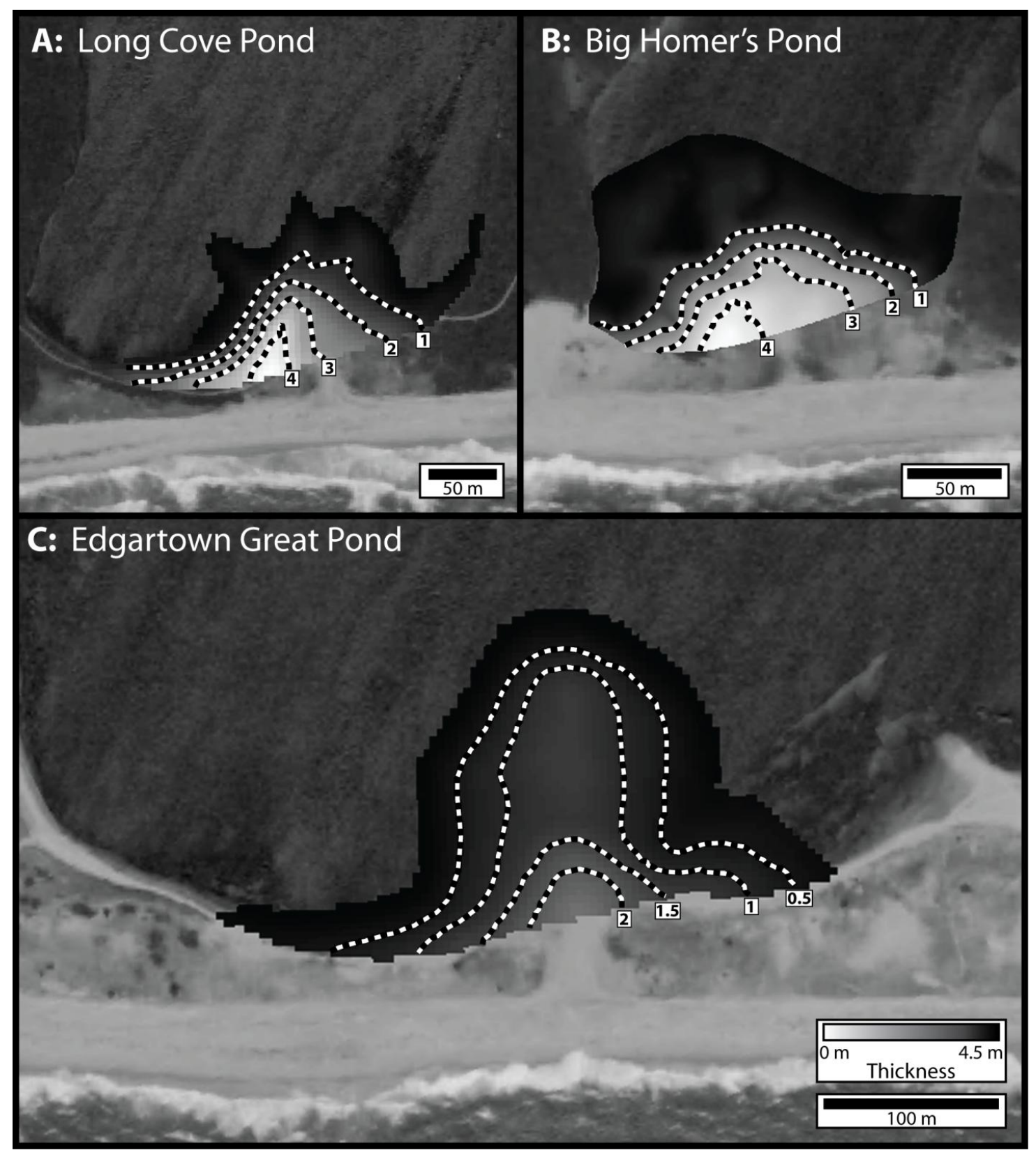

Figure 6: $A, B, C$ are isopach maps of the washovers from Big Homer's Pond, Long Cove Pond, and Edgartown Great Pond, respectively. Contour lines indicated by white and black hashed lines and are at $1 \mathrm{~m}$ intervals for figures $A$ and $B$ and at $1 / 2 \mathrm{~m}$ intervals for figure $C$. Contour labels are in meters. The gray scale is the same for all figures and is indicated in figure $\mathrm{C}$. Note the older washover to the east of the washover of interest in figure $C$. Reworked sediment from this washover was excluded from the isopach seen here, as discussed in text. Maps overlaid on 2008 orthophotos from MassGIS. 
boundary from the modern surface. Washover dimensions and volumes for each of the three ponds are given in table 4. The three fans have similar volumes: the smallest (Big Homer's Pond) is only $12 \%$ smaller than the largest (Edgartown Great Pond). The deposits at Big Homer's Pond and Long Cove Pond demonstrate similar surface areas, and maximum and average thicknesses. The deposit at Edgartown Great Pond covers a surface area $160-180 \%$ larger than the other two. However, it displays a maximum thickness of only $60 \%$, and an average thickness of $40-60 \%$, as thick as the washovers in the other ponds, resulting in the similar washover volumes.

The assumptions made to infer washover volume result in several potential sources of error. The first assumption, the lower boundary is taken as the erosive surface between Units B and C, does not correct for any scour that occurred during the overwash. Such scour would cause the true B/C boundary to be lower than the actual pre-overwash surface. This indicates that some sediment that had previously been located on the landward side of the barriers was scoured and then redeposited as part of the washover unit. Taking the modern $\mathrm{B} / \mathrm{C}$ contact as the pre-overwash topography results in larger washover volume estimates than the volume of sediment that was actually driven landward from the front of the barrier or offshore during the overwash event.

The second assumption that the portion of the washover that contributed to the landward migration of the barrier is that landward of the vegetation line uses a vertical 
plane to truncate the seaward side of the washover deposit. This vertical plane means that the seaward edges of the washovers are represented as a vertical cliff instead of a tapering deposit. The washover deposits do pinch out; however this occurs farther seaward, towards the beach itself.

A final source of error in estimating washover volume is specific to Edgartown Great Pond. Inclusive in the washover isopach is a small lobe of sediment on the eastern side of the deposit that does not appear to originate from the washover of interest, likely resulting from poor data coverage in this region. As seen in orthophotos, this sediment is likely derived from the reworking of adjacent older overwash fans (Fig. 6C), as further evidenced by the concavity of the isopach map along that side of the fan. This sediment was excluded from the volume calculation by extending the $0-m$ contour in a manner parallel to the $0.5 \mathrm{~m}$ contour. The difference in the total washover volume resulting from this truncation is only $0.08 \times 10^{4} \mathrm{~m}^{3}$, or $\sim 3 \%$.

\subsubsection{Dating the Washovers and Correlated Storms}

The washovers on Martha's Vineyard were dated using aerial photos. Cheung et al., (2007) used aerial photos from March 1991 and November 1992 to bracket the overwash events at Long Cove and Big Homer's Ponds to this period (figure 7). Hurricane Bob was the strongest storm during this time period, though the Halloween Eve Storm (the "Perfect Storm") of 30 October 1991 occurred in the same period. The tide gauge at Woods Hole, MA indicates that the Halloween Eve Storm produced 

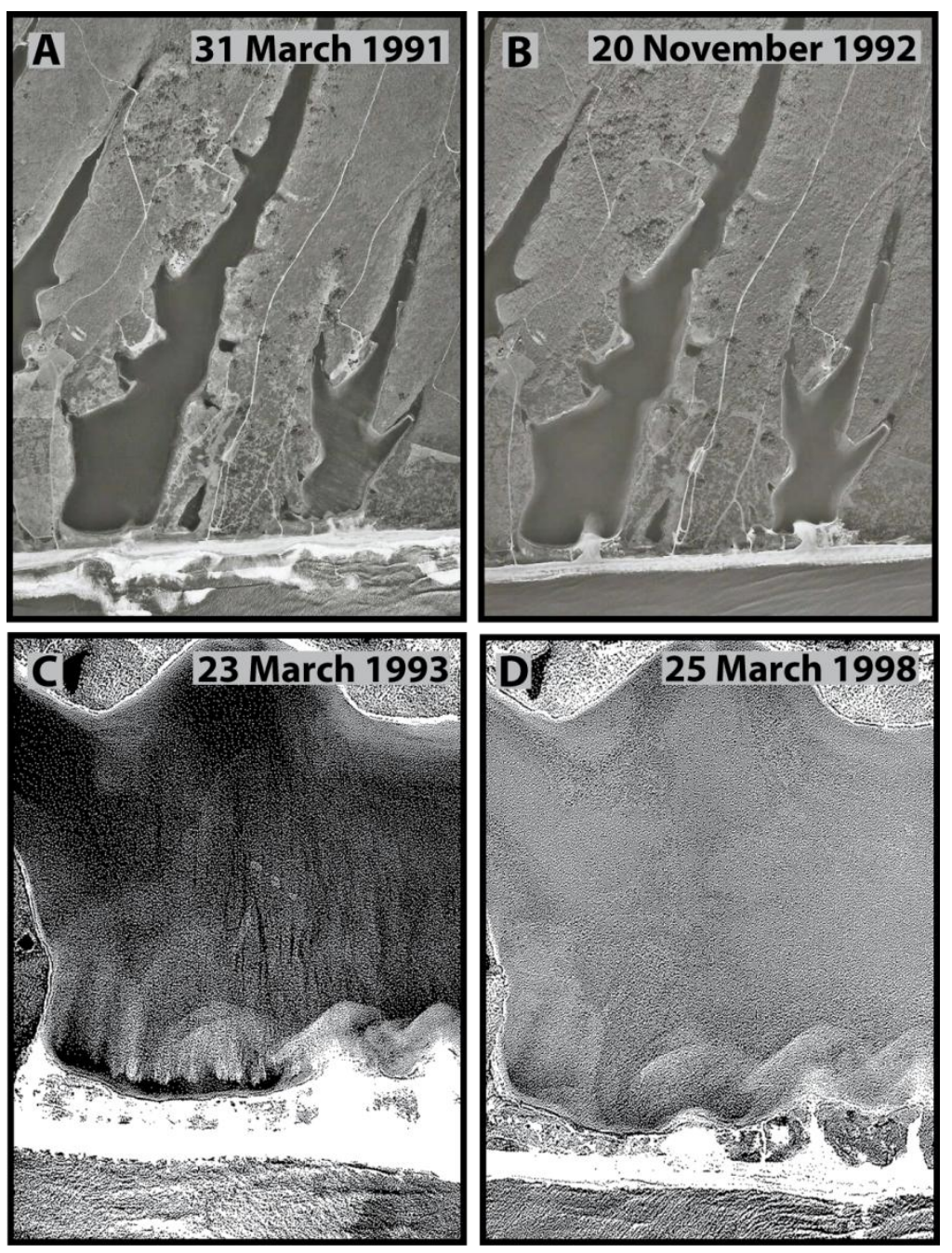

Figure 7: Aerial photos bracketing the deposition of the washovers at Big Homer's and Long Cove Ponds (figures $A$ and $B$ ) and at Edgartown Great Pond (figures $C$ and D). Figure $A$ is from 31 March 1991, figure $B$ is from 20 November 1992, figure $C$ is from 23 March 1993, and figure $D$ is from 25 March 1998. Images in A and B are from Cheung et al., 2007 and images in C and D are from the James W. Sewall Co. 
significant storm tides of $0.94 \mathrm{~m}$ above mean high water (m MHW; NOAA, 2011b).

However, the water level from this nor'easter was not as high as the $1.50 \mathrm{~m} \mathrm{MHW}$ on 19 August 1991 (NOAA, 2011b) produced by Hurricane Bob as it passed $50 \mathrm{~km}$ west of Martha's Vineyard, allowing its strongest winds to directly impact the southerly facing South Beach (Cheung et al., 2007). Hurricane Bob made landfall at Newport Rhode Island as a category 2 storm with winds of $160 \mathrm{kph}$ (figure 8; Mayfield, 1992). The surge created by Hurricane Bob at Long Cove and Big Homer's Ponds was computed using the Sea, Lake, and Overland Surges from Hurricanes (SLOSH) model to give a maximum surge of 1.7 m (Jelesnianski et al., 1992; per. com. Dr. Philip Lane).

The washover at Edgartown Great Pond was deposited later than those at the other ponds. Aerial photos bracket the overwash event between March 1993 and 1998. Tide gauges at Newport, RI and Woods Hole, MA indicate that the highest water level during this interval occurred during a nor'easter on 10 January 1997 with a storm tide of $0.95 \mathrm{~m} \mathrm{MHW}$ at Woods Hole (NOAA, 2011b).

\subsubsection{Recurrence Interval of Storm Water Levels}

The return interval for water levels produced by storms with the characteristics of Hurricane Bob and the January 1997 nor'easter are not well known. The monthly extreme water levels from the Woods Hole tide gauge (NOAA, 2011b) were used to estimate these return intervals. The $90^{\text {th }}$ percentile of the data ( $0.596 \mathrm{~m} \mathrm{MHW)} \mathrm{was}$ determined, and all smaller values were removed. Then a generalized Pareto 
distribution was fit to those data, using 0.596 as the theta (Lin et al., 2010). The fit was evaluated for between 0.6 and $3.6 \mathrm{~m} \mathrm{MHW}$ at $10 \mathrm{~cm}$ intervals. There were 884 months of data with 77 values exceeding $0.6 \mathrm{~m}$, so the average return time for water levels in the $90^{\text {th }}$ percentile is $\sim 1$ year. The cumulative probability from the GPD fit was used to calculate the return intervals for each $10 \mathrm{~cm}$ bin of water levels (figure 8). The return interval for the water level associated with Hurricane Bob is $\sim 28$ years and that associated with the January 1997 nor'easter is 6 years (Lane, 2011).

\subsubsection{Overwash Fluxes}

Given the calculated washover volumes, $V$, the width of barrier affected by the overwash, $W$, and the return interval of the surge that created the deposit, $T_{S}$, onshore sediment fluxes, $Q_{o w}$, for each of the three ponds is estimated as:

$$
Q_{o W}=\frac{V}{W * T_{S}}
$$

Values are given in table 5 based on the estimates of the return times of the storm tides that caused the overwash events. The volume per width of barrier is not the same as that given in table 1 because the width used in table 1 is that of the washover fan itself, while the width presented here is that of the affected section of barrier. The width of the fan and the width of the affected barrier are similar at Big Homer's and Long Cove Ponds, due to the relatively narrow widths of these barriers. However, at Edgartown Great Pond the affected barrier is much longer. These flux values are given assuming 


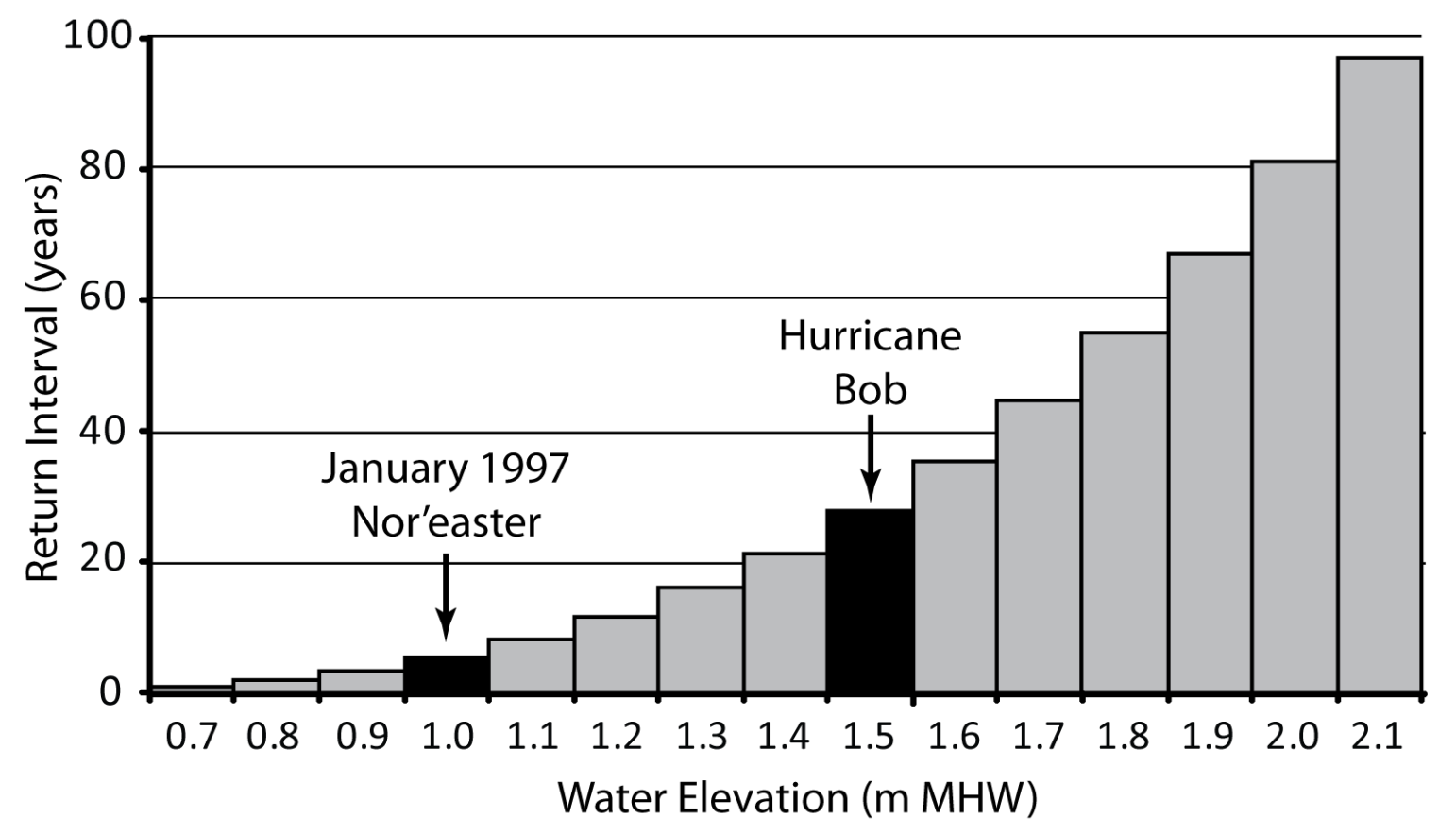

Figure 8: Return intervals for water levels based on Woods Hole, MA tide gauge data. Labels on the horizontal axis are the central values of the $10 \mathrm{~cm}$ bins. The return interval for a water level greater to or equal to that produced by the January 1997 nor'easter is about 6 years and that produced by Hurricane Bob is about 28 years (per. com. Dr. Philip Lane). 
that the barrier overwashes if the water level is greater than or equal to the maximum water level that occurred during the storm that caused each overwash. If a storm does not produce a sufficiently high water level, then it is assumed that there is no onshore sediment flux. The heights of the barriers are not taken into consideration for this calculation.

Table 5: Overwash Fluxes and Associated Parameters

\begin{tabular}{|c|c|c|c|}
\hline & $\begin{array}{l}\text { Big Homer's } \\
\text { Pond }\end{array}$ & Long Cove Pond & $\begin{array}{c}\text { Edgartown Great } \\
\text { Pond }\end{array}$ \\
\hline Washover Volume & $2.1 \times 10^{4} \mathrm{~m}^{2}$ & $2.3 \times 10^{4} \mathrm{~m}^{2}$ & $2.4 \times 10^{4} \mathrm{~m}^{2}$ \\
\hline Affected Barrier Length & $220 m$ & $340 \mathrm{~m}$ & $470 m$ \\
\hline Return Time & $28 \mathrm{yr}$ & $28 \mathrm{yr}$ & $6 \mathrm{yr}$ \\
\hline Vol./Affected Barrier Length & $96 \mathrm{~m}^{3} / \mathrm{m}$ & $68 \mathrm{~m}^{3} / \mathrm{m}$ & $51 \mathrm{~m}^{3} / \mathrm{m}$ \\
\hline Onshore Sediment Flux & $3.4 \mathrm{~m}^{3} / \mathrm{m} / \mathrm{yr}$ & $2.4 \mathrm{~m}^{3} / \mathrm{m} / \mathrm{yr}$ & $8.5 \mathrm{~m}^{3} / \mathrm{m} / \mathrm{yr}$ \\
\hline
\end{tabular}

Despite the similarity in the volumes of the washovers calculated at the three ponds, the ranges of fluxes show the differences in affected barrier width and water elevation return interval. The flux is highest at Edgartown Great Pond due to the short return time of the water level needed to cause the overwash. This suggests that there may be a typical or maximum volume that is deposited as washover once a certain threshold of water elevation is met. Therefore, onshore sediment flux would be maximized when an overwash is caused by the smallest necessary water level: these will 
have much smaller return intervals than the larger storms that produce a similar volume

of washover. If this speculation is true, it would contradict the findings of Kochel and Dolan (1986), who found that larger storms contribute more to overwash flux than smaller frequent storms on southern Assateague Island, MD. This could indicate that there may be a threshold of water level needed to produce the "typical" washover volume and that very small overwash events will not reach this threshold, though future work is needed to expand the data set to verify this suggestion.

\subsection{Part II: Implications}

\subsubsection{Comparison with Previous Work}

Table 1 shows washover volumes per unit width of deposit for many previous studies as well as those discussed here. The values calculated for the three South Beach washover fans range from $120-190 \mathrm{~m}^{3} / \mathrm{m}$. These values are higher than most of those reported in the table and typically coincide with values of washovers deposited by a confined flow (i.e., when the throat of the washover is constricted by high topography so the overwash is channeled through a small opening). The washovers of interest here all have a distinct throat, narrower than the rest of the deposit, so they could be considered confined flow. However, there is no hard structure confining the overwash; rather they are bounded simply by erodible aeolian dunes. Alternatively, the high values from this study could indicate the importance of recognizing the three dimensional nature of the deposit. Not doing so appears to result in an underestimate of the 
normalized washover volumes. Additional work would be necessary to measure the three-dimensional volume of a washover at a location where pre- and post- overwash profiles have been conducted in order to determine if similar values are measured using each method.

\subsubsection{Estimating Washover Volumes from Aerial Photos}

Estimating washover volumes using the methods described here is a timeconsuming and labor-intensive process. It would be vastly simpler if washover fan areas could be determined from orthophotos, as per methods similar to those described by Fisher and Simpson (1970). This estimation is attempted here by determining an "effective washover thickness", defined as the washover volume normalized by the twodimensional washover area visible on orthophotos. Effective washover thickness, $T_{E}$, is determined by dividing the volumes of each fan, $V$, by the areas of each fan determined from orthophotos, $A_{P}$ (table 6) as:

$$
T_{E}=\frac{V}{A_{P}}
$$

The average of the effective thickness value $\left(\left\langle T_{E}\right\rangle=5.6 \mathrm{~m}\right)$ is then multiplied by the fan areas to back-calculate the volume of each fan based only on these two values (not each individual fan's effective thickness). The average error between these back-tracked volumes and the actual fan volumes is only $5 \%$ (table 6 ). These data suggest that it may be possible to determine the volumes of a larger number of washovers on the south 
shore of Martha's Vineyard using only orthophotos and the effective thickness values determined from detailed investigations at a few sites. However, the small sample size presented here indicates that future studies are needed to validate this result especially as the effective thickness was determined from the three fans that were then used to determine the efficacy of the method. Furthermore, it is necessary to apply the methods presented in this study to calculate the three-dimensional volumes of multiple washovers along a shoreline before attempting to use the effective thickness metric to estimate volumes of additional proximal washovers. This approach reflects the variable geometries, wave regimes, exposures, etc. of different shorelines that will lead to different effective thicknesses for each. Once an average effective thickness is calculated for a region, future washover deposit volumes can be calculated quickly and without great expense using only orthophotos.

Table 6: Surface areas of washovers related to volumes. Areas are from 2008 orthophotos with the area calculated for the visible extent of the fans taken seaward to the vegetation line. Effective thicknesses are the volumes of each fan (from table 5) divided by the area from the photos. The backtracked volumes are calculated using the average effective thickness and the areas from the aerial photo. The error refers to the difference between the backtracked volume and the actual volume of the washovers.

\begin{tabular}{ccccc}
\hline & $\begin{array}{c}\text { Big Homer's } \\
\text { Pond }\end{array}$ & $\begin{array}{c}\text { Long Cove } \\
\text { Pond }\end{array}$ & $\begin{array}{c}\text { Edgartown Great } \\
\text { Pond }\end{array}$ & Average \\
\hline Area from Photo & $3600 \mathrm{~m}^{2}$ & $4000 \mathrm{~m}^{2}$ & $4600 \mathrm{~m}^{2}$ & -- \\
Effective Thickness & $5.9 \mathrm{~m}$ & $5.8 \mathrm{~m}^{3}$ & $5.2 \mathrm{~m}^{3}$ & $\mathbf{5 . 6 \mathrm { m }}$ \\
Backtracked Volume & $20200 \mathrm{~m}^{3}$ & $22400 \mathrm{~m}^{3}$ & $25800 \mathrm{~m}^{3}$ & -- \\
Error & $4.0 \%$ & $2.6 \%$ & $7.3 \%$ & $4.7 \%$ \\
\hline
\end{tabular}


A

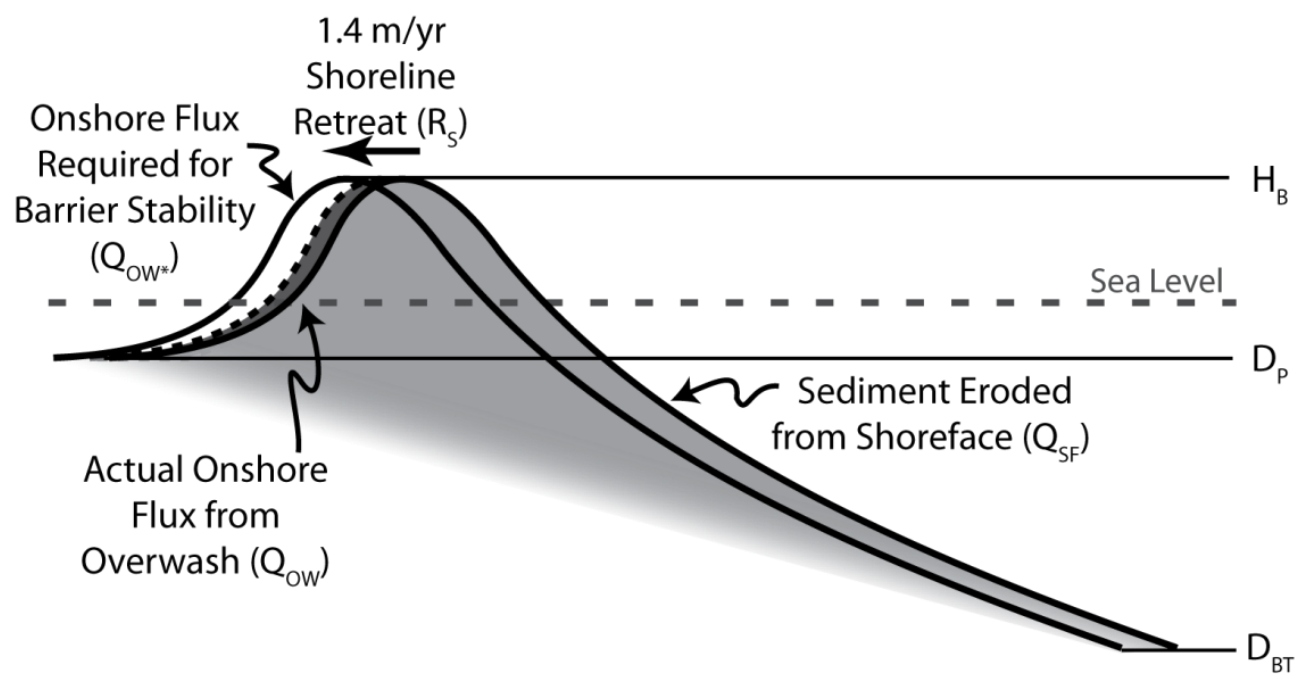

B

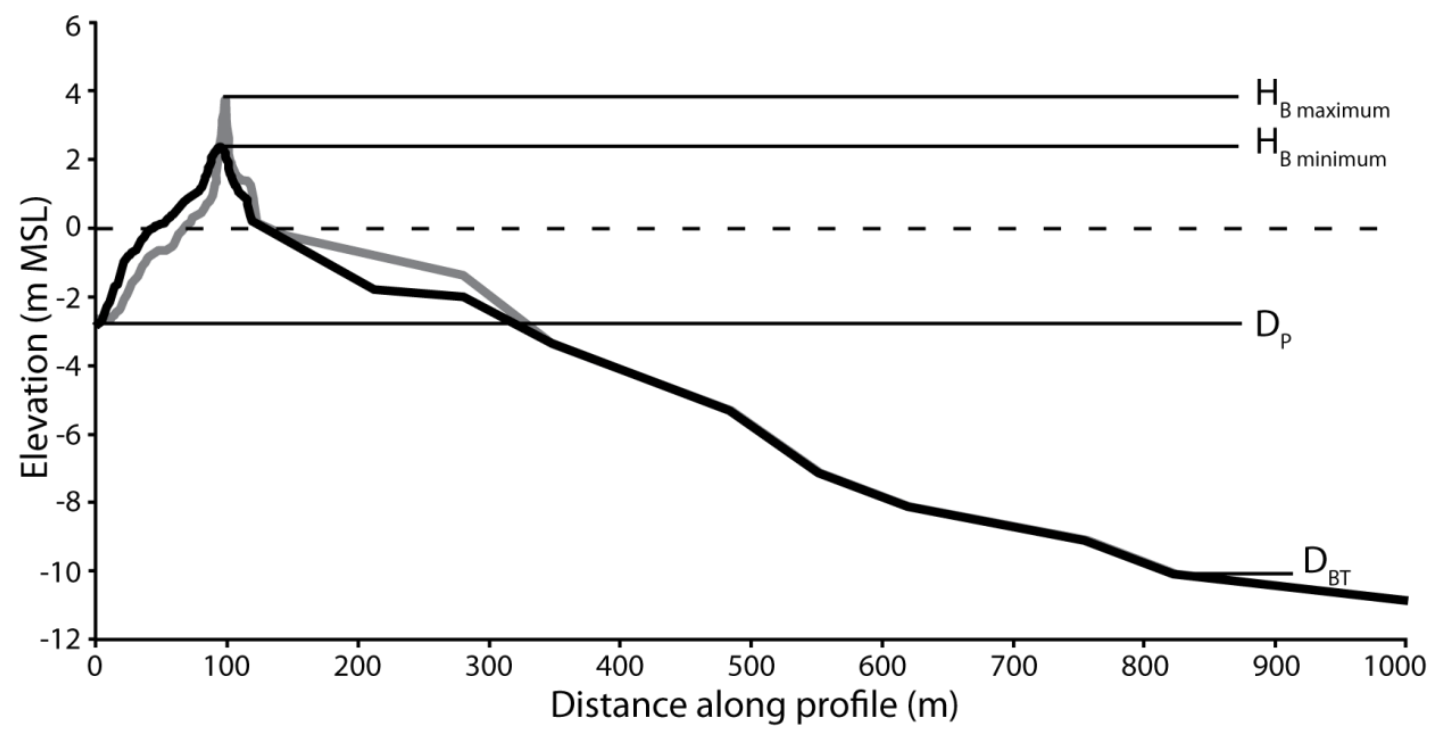

Figure 9: Figure A: Schematic depicting the amount of onshore sediment flux, $Q_{0 w^{*}}$ required to maintain a stable barrier width during shoreline retreat, $R_{S F}$, related to the actual amount of onshore sediment flux from overwash, Qow. Heights used in the estimation are the pond depth, $D_{P}$, barrier toe depth, $D_{B T}$, and barrier height, $H_{B}$. Figure $B$ : Heights used in estimation from minimum and maximum from example profiles at Big Homer's Pond. 


\subsubsection{Implications for Long-term Barrier Evolution}

The south shore of Martha's Vineyard is retreating at a rate of about $1.4 \mathrm{~m} / \mathrm{yr}$ (Hapke et al., 2010) over the last 200 years. In a simple geometric model of barrier transgression, a barrier is able to maintain its form and migrate landward, if it overwashes at a rate defined by its geometric constraints, $Q_{o w^{*}}$ (figure 9 ). Using a priori information about the barrier geometry (pond depth, $D_{P}$, barrier height, $H_{B}$, and barrier toe depth, $D_{B T}=-10 \mathrm{~m}$; presented in table 2 ) and shoreline retreat rate, $R_{S}$, this flux can be estimated from equation 3 and the amount of sediment eroded from the shoreface, $Q_{S F}$, can be estimated from equation 4 assuming that sediment is eroded evenly from the entire shoreface.

$$
\begin{aligned}
& Q_{O W^{*}}=\left(D_{P}+H_{B}\right) * R_{S} \\
& Q_{S F}=\left(H_{B}+D_{B T}\right) * R_{S}
\end{aligned}
$$

Table 7 contains the fluxes necessary to maintain a stable barrier at each pond using the range of barrier heights at each pond as well as an estimated flux of sediment eroded from the shoreface. The overwash flux necessary for the barrier to maintain a stable shape averaged over the three ponds is $\sim 10 \mathrm{~m}^{3} / \mathrm{m} / \mathrm{yr}$. This is about half of the material removed from the shoreface, $\sim 19 \mathrm{~m}^{3} / \mathrm{m} / \mathrm{yr}$ using the shoreface depth to the barrier toe of $\sim-10 \mathrm{~m}$. The other material removed from the shoreface is either due to the alongshore flux gradients (part of the littoral cell beginning with the updrift bluffs and terminating in Wasque Shoal) or transported offshore beyond the active shoreface toe 
during storms. This excess material could also be deposited as washover and actually cause the barrier to grow. The actual onshore sediment flux due to overwash estimated here is less than the value needed to maintain the barrier in its current shape (figure 9; see tables 6 and 7 for values), although values are within an order of magnitude and the high end of the range in fluxes calculated at Edgartown Great Pond does approach this value. It is also important to note that aeolian processes can also contribute to sediment fluxes. Aeolian transport is not quantified here and could result in increased values of onshore sediment flux. The lower sediment flux from overwash calculated here suggests that South Beach is not in steady state and is thinning. Orthophotos show that the barrier width near the three fans studied here has decreased by 15 m between 1994 and 2008. This value is equivalent to a decrease in barrier width of $\sim 1.1 \mathrm{~m} / \mathrm{yr}$. This means that $\sim 24 \%$ of the onshore sediment flux needed to maintain the retreating barrier is occurring, or about $2.4 \mathrm{~m}^{3} / \mathrm{m} / \mathrm{yr}$. This value is remarkably similar to the fluxes calculated at Long Cove and Big Homer's Ponds (2.4 and $3.4 \mathrm{~m}^{3} / \mathrm{m} / \mathrm{yr}$, respectively) and smaller than that calculated at Edgartown Great Pond $\left(8.5 \mathrm{~m}^{3} / \mathrm{m} / \mathrm{yr}\right)$. Leatherman (1979) suggests that overwash is infrequent until a barrier thins to a critical barrier width. After this point, overwash increases and the barrier is able to migrate onshore. Accelerated sea-level rise and increased storm intensities and/or frequencies could prove beneficial to South Beach as these factors will likely increase the frequency of overwash. Relative sea level rise would also decrease the magnitude of the surge needed for the barrier to overwash. These factors would allow for the barrier to have an increased onshore 
sediment flux thereby potentially allowing for it to maintain and migrate onshore as sea level rises.

Table 7: Overwash fluxes needed for the barrier to maintain a stable shape and sediment removed from the shoreface based on the minimum and maximum heights of the barrier at each washover and a shoreline retreat rate of $-1.4 \mathrm{~m} / \mathrm{yr}$.

\begin{tabular}{ccc}
\hline Pond & $\begin{array}{c}\text { Overwash Flux Necessary } \\
\left(\mathbf{Q}_{\mathrm{ow}^{*}}\right), \mathbf{~ m}^{\mathbf{3}} / \mathbf{m} / \mathbf{y r}\end{array}$ & $\begin{array}{c}\text { Sediment Removed } \\
\text { from Shoreface }\left(\mathbf{Q}_{\mathrm{sF}}\right) \\
\mathbf{m}^{\mathbf{3}} \mathbf{m} / \mathbf{m} / \mathbf{y r}\end{array}$ \\
\hline Big Homer's Pond: maximum & 9.8 & 20.0 \\
Big Homer's Pond: minimum & 7.4 & 17.6 \\
Long Cove Pond: maximum & 12.0 & 21.1 \\
Long Cove Pond: minimum & 7.2 & 16.3 \\
Edgartown Great Pond: maximum & 14.9 & 21.9 \\
Edgartown Great Pond: minimum & 9.3 & 16.3 \\
Average & $\mathbf{1 0 . 1}$ & $\mathbf{1 8 . 9}$ \\
\hline
\end{tabular}

\section{Conclusions}

The washovers at Big Homer's and Long Cove Ponds were deposited in 1991 during Hurricane Bob and contain 2.1 and $2.3 \times 10^{4} \mathrm{~m}^{3}$ of sediment, respectively. The onshore sediment flux resulting from these overwash events is about $3.4-2.4 \mathrm{~m}^{3} / \mathrm{m} / \mathrm{yr}$. The washover at Edgartown Great Pond was deposited in 1997 during a January nor'easter, contains $2.4 \times 10^{4} \mathrm{~m}^{3}$ of sediment, and represents an onshore sediment flux of about $8.5 \mathrm{~m}^{3} / \mathrm{m} / \mathrm{yr}$. These values of flux are estimates as they rely on the recurrence intervals obtained from the relatively short tide gauge record and assume that only water levels are necessary to predict when overwash will occur. 
The volumes of these washovers are similar to those deposited as confined flows in previous studies (table 1). The washovers here were confined only by small, erodible dunes that were likely widened during overwash, so the high values may indicate that washover volumes are underestimated when the three dimensional structure of the deposit is not taken into consideration.

The three washovers studied here have similar effective thicknesses, defined as the washover volume normalized by the two-dimensional washover area visible on orthophotos. This result implies broader applicability of the methods and suggests that volumes of other present and future washovers on the south shore of Martha's Vineyard can be estimated based on their two dimensional spatial area as measured from orthophotos.

The most important conclusion from this study is that regarding barrier evolution. Using a simple geometric model of the barrier retreating at $1.4 \mathrm{~m} / \mathrm{yr}$, an average value of onshore sediment flux needed to maintain the barrier of $\sim 10 \mathrm{~m}^{3} / \mathrm{m} / \mathrm{yr}$ is estimated. This value is higher than the fluxes calculated at Big Homer's and Long Cove Ponds, with the flux at Edgartown Great Pond nearing this value. This result indicates that the barrier is out of equilibrium and is thinning under conditions of sealevel rise and shoreline retreat, a situation confirmed by orthophotos. Assuming continued barrier thinning; more frequent overwash is likely, leading to two possible outcomes: overwash will provide adequate onshore sediment flux to maintain a barrier 
of at least a minimum width, or the barrier will continue to thin and eventually drown. Numerical models of barrier evolution are needed to provide insight into which of these options is most likely to occur given estimates of future sea-level rise and storm climate. 


\section{References}

Baker, G.S., Jordan, T.E., and Pardy, J. 2007, An introduction to ground penetrating radar (GPR), in: Baker, G.S., and Jol, H.M., (Eds.), Stratigraphic Analyses Using GPR, Geol. Soc. Amer. Sp. P., 432, p. 1-18.

Balco, G, Stone, J.O.H., Porter, S.C., and Caffee, M.W., 2002, Cosmogenic-nuclide ages for New England coastal moraines, Martha's Vineyard and Cape Cod, MA, USA, Quat. Sci. Rev., 21, p. 2127-2135.

Balco, G., Briner, J., Finkel, R.C., Rayburn, J.A., Ridge, J.C., and Schaefer, J., 2009, Regional beryllium-10 production rate calibration for late-glacial northeastern North America, Guat. Geochron., 4, p. 93-107.

Boothroyd, J.C., Friedrich, N.E. and McGinn, S.R., 1985, Geology of microtidal coastal lagoons: Rhode Island: in: Oertel, G.F. and Leatherman S.P. (Eds.), Barrier Islands. Mar. Geol., 63: 35--76.

Brown, C.W., 1939, Hurricanes and shoreline changes in Rhode Island, Geograph. Rev., 29, p. 416-430.

Bruun, P., 1962, Sea-level rise as a cause of shore erosion, Proc. of the ASCE, J. Waterways \& Harbors Div., 88, p. 117-130.

Buynevich, I.V., FitzGerald, D.M., and van Heteren, S., 2004, Sedimentary records of intense storms in Holocene barrier sequences, Maine, USA, Mar. Geol., SI

Byrnes, M.R. and Gingerich, K.J., 1987, Cross-island profile response to Hurricane Gloria, in: Kraus, N.C. (Ed.), Coastal Sediments '87, American Society of Civil Engineers, New York, NY, p. 1486-1502.

Cheung, K. F., Tang, L., Donnelly, J.P., Scileppi, E.M., Liu, K.-B., Mao, X.-Z., Houston, S.H., and Murnane, R.J., 2007, Numerical modeling and field evidence of coastal overwash in southern New England from Hurricane Bob and implications for paleotempestology, J. Geophys. Res., 112, F03024.

Cowell, P.J., Roy, P.S., and Jones, R.A., 1995, Simulation of large-scale coastal change using a morphological behavior model, Marine Geology, 126, p. 45-61.

Cromwell, J.E., 1971, Barrier coast distribution: a world-wide survey, Abstract in: Second National Coastal Sallow Water Research Conference, Baton Rouge, LA, p. 50.

D’Amore, D.W., 1983, Hydrogeology and geomorphology of Great Sandford outwash plain, York County, ME with particular emphasis on the Branch Brook Watershed, Ph.D. Diss., Geol. Dept., Boston Univ., Boston, MA, 147 p.

Davis, R.A., Jr. (Ed.), 1985, Coastal Sedimentary Environments, Springer-Verlag, New York, $716 \mathrm{p}$. 
Dean, R.G., and Maurmeyer, E.M., 1983, Models for beach profile response, in Komar, P.D., ed., Handbook of Coast. Proc. and Erosion: Boca Raton, Florida, USA, CRC Press, p. 151-165.

Dillon, W.P., 1970, Submergence effects on a Rhode Island barrier and lagoon inferences on migration of barriers, J. Geol., 78, 94-106.

Dolan, R. and Godfrey, P., 1973, Effects of Hurricane Ginger on the barrier islands of North Carolina, Geol. Soc. Amer. Bull., 84, p. 1329-1334.

Donnelly, C., Kraus, N., and Larson, M., 2006, State of knowledge on measurement and modeling of coastal overwash, J. of Coastal Res., 22, p. 965-991.

Donnelly, J. P., Cleary, P., Newby, P., and Ettinger, R., 2004, Coupling instrumental and geological records of sea-level change: Evidence from southern New England of an increase in the rate of sea-level rise in the late 19th century, Geophys. Res. Lett., 31, L05203.

Donnelly, J.P., Bryant, S.S., Butler, J., Dowling, J., Fan, L., Hausmann, N., Newby, P.N., Shuman, B., Stern, J., Westover, K., and Webb, T., III, 2001a, A 700-year sedimentary record of intense hurricane landfalls in southern New England, Geol. Soc. Amer. Bul., 113, p. 714-727.

Donnelly, J.P., Rolls, S., Wengren, M., Butler, J., Lederer, R., and Webb, T., III, 2001b, Sedimentary evidence of intense-hurricane strikes from New Jersey, Geol., 29, p. 615-618.

Eiser, W.C. and Birkemeier, M., 1991, Beach profile response to Hurricane Hugo, Proc. Coast. Sed. 1991, Seattle, Washington, ASCE, p. 1681-1696.

Emanuel, K., Sundararajan, R., and Williams, J., 2008, Hurricanes and global warming: Results from downscaling IPCC AR4 simulations, Bull. Amer. Meteor. Soc., 89, p. 347-367.

Fisher, J.J. and Simpson, E.J., 1979, Washover and tidal sedimentation rates as environmental factors in development of a transgressive barrier shoreline, in: Leatherman, S.P. (Ed.), Barrier Islands from the Gulf of St. Lawrence to the Gulf of Mexico, Academic Press, Inc., New York, p. 127-148.

Fisher, J.S., and Stauble, D.K., 1977, Impact of Hurricane Belle on Assateague Island washover, Geology, 5, 765-768.

Fisher, J.S.; Leatherman, S.P., and Perry, F.C., 1974, Overwash processes on Assateague Island, Proc. 14th Coast. Engng. Conf. Copenhagen, Denmark, ASCE, p. 11941211. 
FitzGerald, D.M., 1993, Origin and stability of tidal inlets in Massachusetts, in: Aubrey, D.G., and Giese, G.S., (Eds.), Formation and Evolution of Multiple Tidal Inlet Systems, Washington, D.C., Amer. Geophys. Un., p. 1-61.

FitzGerald, D.M., Rosen, P.S., and van Heteren, S., 1994, New England barriers, in: Davis, R.A., (Ed.), Geology of Holocene Barrier Island Systems, Berlin: Springer-Verlag, p. 305-394.

Frumhoff, P.C., McCarthy, J.J, Melillo, J.M., Moser, S.C., and Wuebbles, D.J., 2007, Confronting Climate Change in the U.S. Northeast: Science, Impacts, and Solutions, Synthesis report of the Northeast Climate Impacts Assessment (NECIA). Cambridge, MA: Union of Concerned Scientists (UCS).

Glaeser, J.D., 1978, Global distribution of barrier islands in terms of tectonic setting. J. Geol., 86: 283--298.

Hapke, C.J., Himmelstoss, E.A., Kratzmann, M., List, J.H., and Thieler, E.R., 2010, National assessment of shoreline change; historical shoreline change along the New England and Mid-Atlantic coasts: U.S. Geological Survey Open-File Report 2010$1118,57 \mathrm{p}$.

Hayes, M.O., 1979, Barrier island morphology as a function of tidal and wave regime, in: Barrier islands from the Gulf of St. Lawrence to the Gulf of Mexico, ed. S.P. Leatherman, Academic Press, Inc. New York, NY, p. 1-28.

Howard, A.D., 1939, Hurricane modifications of the offshore bar of Long Island, New York. Geog. Rev., 29, p. 400-415.

Inman, D.L. and Nordstrom, C.E., 1971, On the tectonic and morphologic classification of coasts, J. Geol., 79: 1--21.

JALBTCX (Joint Airborne Lidar Bathymetry Technical Center of eXpertise), 2009, 2007 US Army Corps of Engineers (USACE) Topo/Bathy Lidar: Maine, Massachusetts, and Rhode Island, Charlotte, SC: NOAA's Ocean Service (NOS), Coastal Services Center (CSC).

Jelesnianski, C. P., Chen, J., and Shaffer, W.A., 1992, SLOSH: Sea, lake, and overland surges from hurricanes, NOAA Tech. Rep., NWS 48, 71 p.

Kaye, C.A., 1964a, Outline of Pleistocene geology of Martha's Vineyard, Massachusetts. U.S., Geol. Surv., Prof. Pap., 501C, p. C134-Cl39.

Kaye, C.A., 1964b, Illinoian and early Wisconsin moraines of Martha's Vineyard, Massachusetts, U.S. Geol. Surv., Prof. Pap.,501C, p. 140-143.

Knapp, K. R., Kruk, M.C., Levinson, D.H., Diamond, H.J., and Neumann, C.J., 2010, The International Best Track Archive for Climate Stewardship (IBTrACS): Unifying tropical cyclone best track data. Bull. Amer. Meteor. Soc., 91, 363-376. 
Kochel, R.C. and Dolan, R., 1986, The role of overwash on a mid- Atlantic coast barrier island, J. Geol., 94, p. 902-906.

Landsea, C.W., Anderson, C., Charles, N., Clark, G., Dunion, J., Fernández-Partagás, J., Hungerford, P., Neumann, C., Zimmer, M., 2004, The Atlantic hurricane database reanalysis project: documentation for 1851-1910 alterations and additions to the HURDAT database, In: Liu, K. (Ed.), Murnane, R. Past, Present and Future, Columbia Press, New York, Hurricanes and Typhoons, p. 177-221.

Lane, D.P., 2011, Late Holocene Hurricane Activity and Climate Variability in the Northeastern Gulf of Mexico, PhD. Diss., Joint Program in Oceanography/Applied Ocean Science and Engineering, Massachusetts Institute of Technology, Dept. of Earth, Atmospheric, and Planetary Sciences; and the Woods Hole Oceanographic Institution.

Leatherman, S. P. and Zaremba, R.E., 1987, Overwash and aeolian processes on a U.S. northeast barrier, Sed. Geol., 52, p. 183-206.

Leatherman, S.P., 1976, Barrier island dynamics: overwash processes and eolian transport, Proceedings of the 15th Coastal Engineering Conference, Honolulu, Hawaii: Amer. Soc. of Civil Engs., p. 1958-1974.

Leatherman, S.P., 1979a, Beach and dune interactions during storm conditions, Q. J., Engng. Geol., 12, p. 281-290.

Leatherman, S.P., 1979b, Migration of Assateague Island, Maryland, by inlet and overwash processes, Geol., 7, p. 104--107.

Leatherman, S.P., 1983, Barrier dynamics and landward migration with Holocene sealevel rise, Nature, 301 p. 415-417.

Leatherman, S.P., 1985, Geomorphic and stratigraphic analysis of Fire Island, New York, in: Oertel, G.F. and Leatherman, S.P. (Eds.), Barrier Islands. Mar. Geol., 63 : 173-195.

Leatherman, S.P., Williams, A.T. and Fisher, J.S., 1977, Overwash sedimentation associated with a large-scale northeaster, Mar. Geol., 24, 109--121.

Lin, N., Emanuel, K.A., Smith, J.A., and Vanmarcke, E., 2010, Risk assessment of hurricane storm surge for New York City. J. Geophys. R., 115, D18121.

Liu, K. B., and Fearn, M.L., 2000, Reconstruction of prehistoric landfall frequencies of catastrophic hurricanes in northwestern Florida from lake sediment records, Quat. Res., 54, p. 238- 245.

Mayfield, M., 1992, Preliminary Report Hurricane Bob 16-20 August 1991, Nat. Hurricane Cent., 21 p. 
Mitrovica, J.X., Gomez, N., and Clark, P.U., 2009, The sea-level fingerprinting of West Antarctic collapse, Science, 323, p. 753.

Morton, R.A. and Paine, J.G., 1985, Beach and vegetation-line changes at Galveston Island, Texas: erosion, deposition, and recovery from Hurricane Alicia, Univ. Texas, Austin, Bureau of Econ. Geol., Geol. Circ., 85, 39 p.

Morton, R.A. and Sallenger, A.H., Jr., 2003, Morphological impacts of extreme storms on sandy beaches and barriers, J. Coast. R., 19, p. 560-573.

Munsell, 2000, Munsell soil color chart: Baltimore, Md., 22 p.

Nelson, D.D., 1991, Factors effecting beach morphology changes caused by Hurricane Hugo, northern South Carolina, in: Finkl, C.W. and Pilkey, O.H. (Eds.), Impacts of Hurricane Hugo, September 10-22, 1989, J. Coast. Res. Sp. Is. 8, p. 163-179.

Neumann, C.J., Jarvinen, B.R., McAdie, C.J., Elms, J.D., 1993, Tropical cyclones of the North Atlantic Ocean, 1871-1992, Natl Climatic Data Cent. Natl Hurricane Cent. Hist. Climatol. Ser., 6-2, 193.

Nichols, R.L. and Marston, A.F., 1939, Shoreline changes in Rhode Island produced by Hurricane of September 21, 1938. Bull. Geol. Soc. Amer., 50, p. 1357-1370.

NOAA, 2010, Water level tidal predictions, MA, Martha's Vineyard and Vineyard Sound, http://tidesandcurrents.noaa.gov/tides10/tab2ec1b.html\#12 (accessed 1 Dec. 2010).

NOAA, 2011a, Extremes, Newport, RI, Station ID 8452660, http://tidesandcurrents.noaa.gov/data_menu.shtml?extremetype=maxmin\&bda te $=19300101 \&$ edate $=20111231 \&$ unit $=0 \&$ format $=$ Apply+Change \&stn $=8452660+$ Newport\%2C+RI\&type=Extremes (accessed 12 May 2011).

NOAA, 2011b, Extremes, Woods Hole, MA, Station ID 8447930, http://tidesandcurrents.noaa.gov/data_menu.shtml?extremetype=maxmin\&bda te $=19320101 \&$ edate $=20110608 \&$ unit $=0 \&$ format $=$ Apply + Change $\&$ stn $=8447930+$ Woods+Hole\%2C+MA\&type=Extremes (accessed 12 May 2011).

NOAA, 2011c, Mean sea-level trend 8447930 Woods Hole, MA, http://tidesandcurrents.noaa.gov/sltrends/sltrends_station.shtml?stnid=844793 0\%20Woods\%20Hole,\%20MA (accessed 12 May 2011).

Ogden, J.G. III, 1974, Shoreline changes along the southeastern coast of Martha's Vineyard, MA for the past 200 years, Quart. Res., 4, p. 496-508.

Oldale, R.N. 1982. Pleistocene stratigraphy of Nantucket, Martha's Vineyard, the Elizabeth Islands, and Cape Cod, Massachusetts, In: Larson, G.J., and Stone, B.D. (Eds.), Late Wisconsinian glaciation of New England, 34 p. 
Oldale, R.N., and Barlow, R.A., 1986, Geologic map of Cape Cod and the Islands, Massachusetts, U.S. Geol. Surv., Misc. Invest., Map 1-1763, 1 sheet.

Orford, J.; Jennings, S., and Pethick, J., 2003, Extreme storm effect on gravel dominated barriers, in: Proceedings Coastal Sediments '03. Corpus Christi, Texas: World Scientific Press and East Meets West Productions, $14 \mathrm{p}$.

Pierce, J.W., 1970, Tidal inlets and washover fans, J. Geol., 8, p. 230--234.

Reardon, L.F., 1926, The Florida Hurricane and Disaster, Miami Publishing Co., Miami.

Redfield, A.C. and Miller, A.R., 1957, Water levels accompanying Atlantic coast hurricanes, Meteorol. Mon., 2, p. 1-23.

Sallenger, A.H., JR., 2000, Storm impact scale for barrier islands, J. Coast. R., 16, p. 890895.

Schwartz, R.K., 1975. Nature and Genesis of Some Storm Washover Deposits, Coast. Engng. Res. Cnt. Tech. Mem. 61, 69p.

Simpson, R.H. and Hope, J.R., 1971, Atlantic hurricane season of 1971, Monthly Weather Rev., 100, p. 256-267.

Stockdon, H.F., A.H. Sallenger, R.A. Holman, and P.A. Howd, 2007, A simple model for the large-scale, spatially-variable coastal response to hurricanes, Mar. Geol., 238, p. 1-20.

Stolper, D., List, J.H., and Thieler, E.R., 2005, Simulating the evolution of coastal morphology and stratigraphy with a new morphological-behaviour model (GEOMBEST), Marine Geology, 218, p. 17-36.

Stone, B.D., Borns, H.W., Jr., 1986, Pleistocene glacial and interglacial stratigraphy of New England, Long Island, and adjacent Georges Bank and Gulf of Maine, in: Sibrava, V., Bowen, D.Q., Richmond, G.M. (Eds.), Quaternary Glaciations in the Northern Hemisphere, Quat. Sci. Rev. 5, p. 39-52.

Stutz, M.L. and Pilkey, O.H., 2011, Open-ocean barrier islands: global influence of climatic, oceanographic, and depositional settings. J. Coast. R., 27, p. 207-222.

U.S. Army Corps of Engineers, 1963, Operation Five High, North Atlantic Div. Rep., 120 p.

Uchupi, E., and Oldale, R.N., 1994, Spring sapping origin of the enigmatic relict valleys of Cape Cod and Martha's Vineyard and Nantucket Islands, MA, Geomorph., 9, p. 83-95.

Vermeer, M., and Rahmstorf, S., 2009, Global sea level linked to global temperature: Proc. Nat. Acad. Sci., 106, p. 21527-21532.

Viles, H., and Spencer, T., 1995, Coastal Problems, Arnold, London, 352 p. 
Wilby, F.B., Young, G.R., Cunningham, C.H., Lieber, A.C., Hale, R.K., Saville, T., and O'Brien, M.P., 1939, Inspection of beaches in path of the Hurricane of September 21, 1938, Shore and Beach, 7, p. 43-47.

Wolinsky, M.A., and Murray, A.B., 2009, A unifying framework for shoreline migration: 2. Application to wave-dominated coasts, J. Geophys. Res., 114, F01009.

Woodworth, J.B., and Wigglesworth, E., 1934, Geography and geology of the region including Cape Cod, the Elizabeth Islands, Nantucket, Martha's Vineyard, No Mans Land, and Block Island, Harvard Coll. Mus. of Comp. Zoo. Mem., 52, 322 p. 


\section{A. Appendix: Graphic core logs, radiographs, verbal descriptions of sediment cores.}

\section{A.1. Explanation}

\section{Explanation}

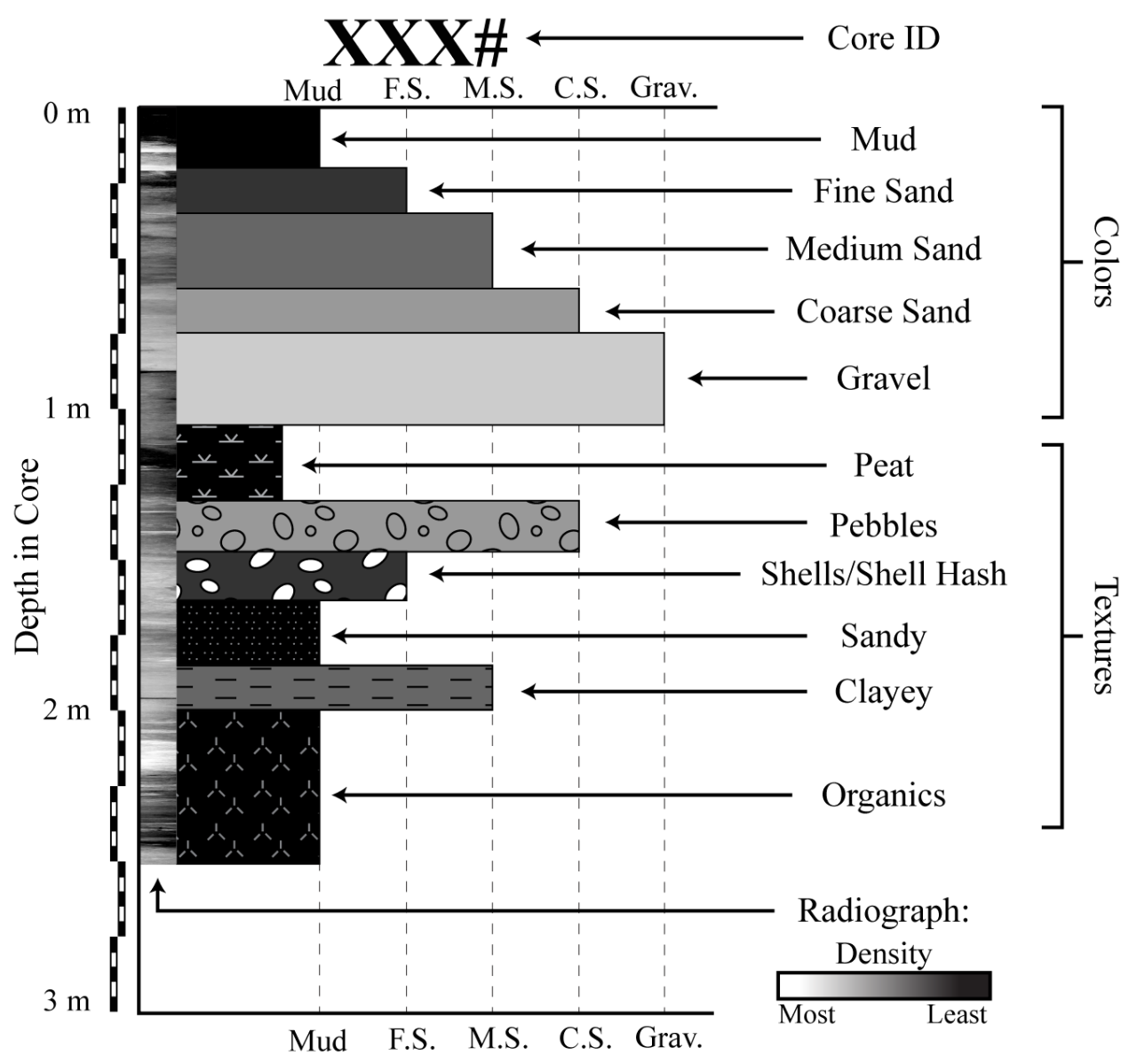

$X X X \#$

\begin{tabular}{|c|c|c|c|c|c|}
\hline section & start & end & grain size & color & comments \\
\hline $\begin{array}{c}\text { Section } \\
\text { \# : total } \\
\text { \# of } \\
\text { core } \\
\text { sections }\end{array}$ & $\begin{array}{l}\text { Start } \\
\text { of } \\
\text { layer } \\
(\mathrm{cm})\end{array}$ & $\begin{array}{l}\text { End } \\
\text { of } \\
\text { layer } \\
(\mathrm{cm})\end{array}$ & $\begin{array}{l}\text { Sediment } \\
\text { size }\end{array}$ & $\begin{array}{l}\text { Munsell } \\
\text { (2000) } \\
\text { sediment } \\
\text { color }\end{array}$ & $\begin{array}{l}\text { Any comments on textures, organics, contacts, } \\
\text { etc. }\end{array}$ \\
\hline
\end{tabular}

Abbreviations: v.f. sand: very fine sand; f. sand/F.S.: fine sand; m. sand/med. Sand/M.S.: medium sand; c. sand/C.S.: coarse sand; v.c. sand: very coarse sand; gav.: gravel; gran.: granules; orgs.: organics; pebb.: pebbles; sed.: sediment; frag.: fragments. 


\section{A.2. Big Homer's Pond Cores}

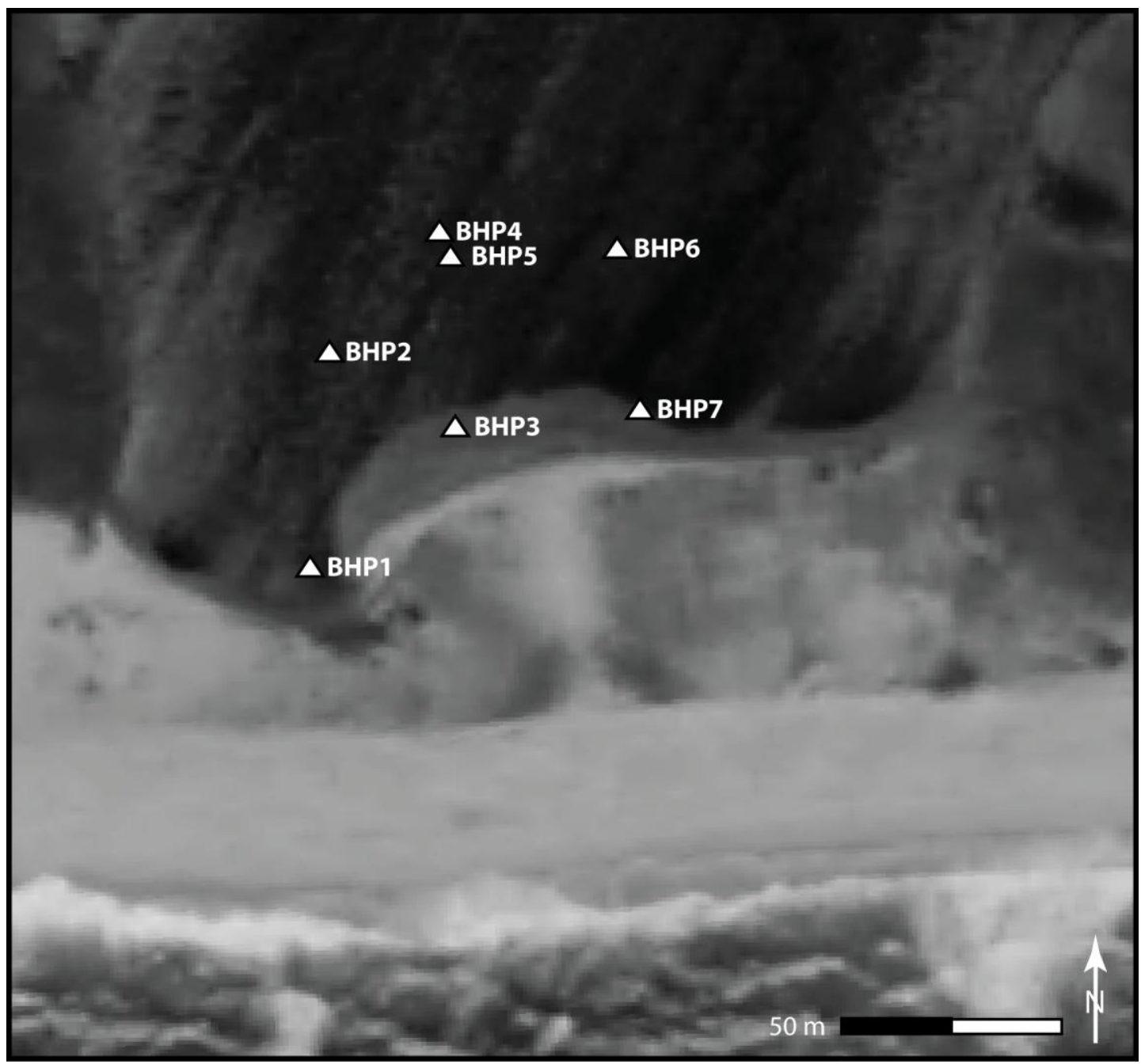

The above figure indicated core locations at Big Homer's Pond. The following graphic core logs, radiographs, and verbal descriptions follow the same explanation as detailed in section A.1. 
BHP1

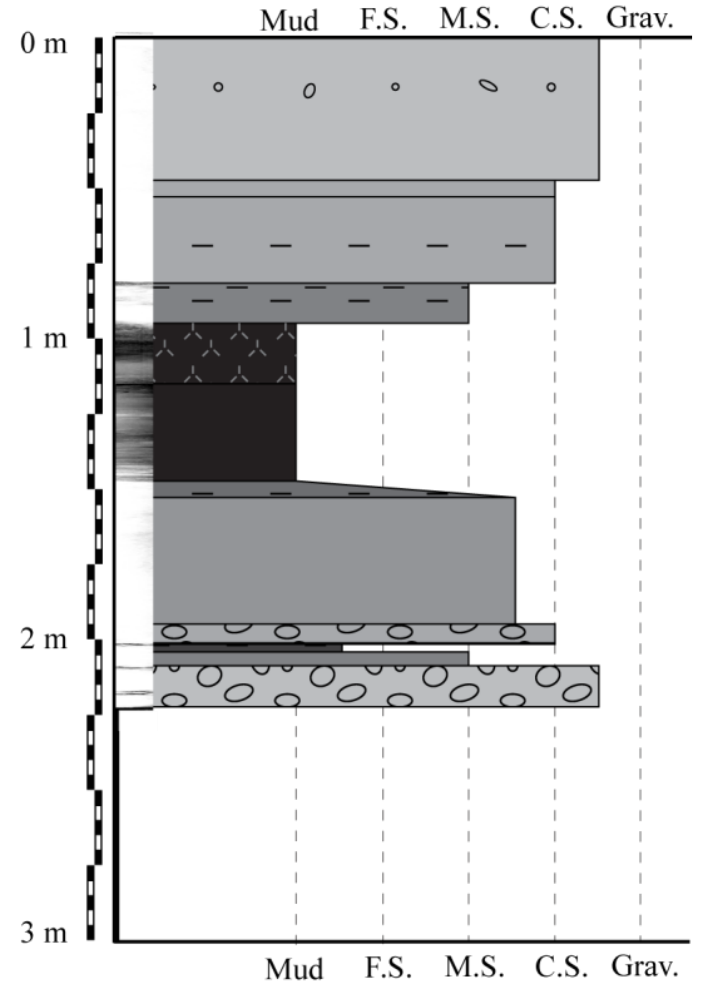

BHP3

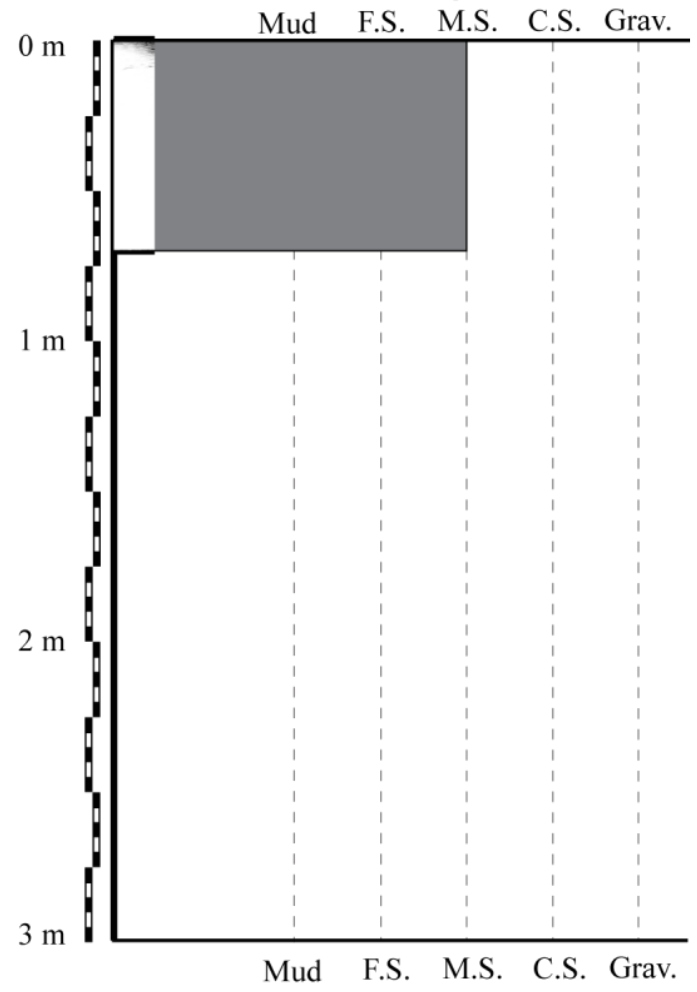

BHP2

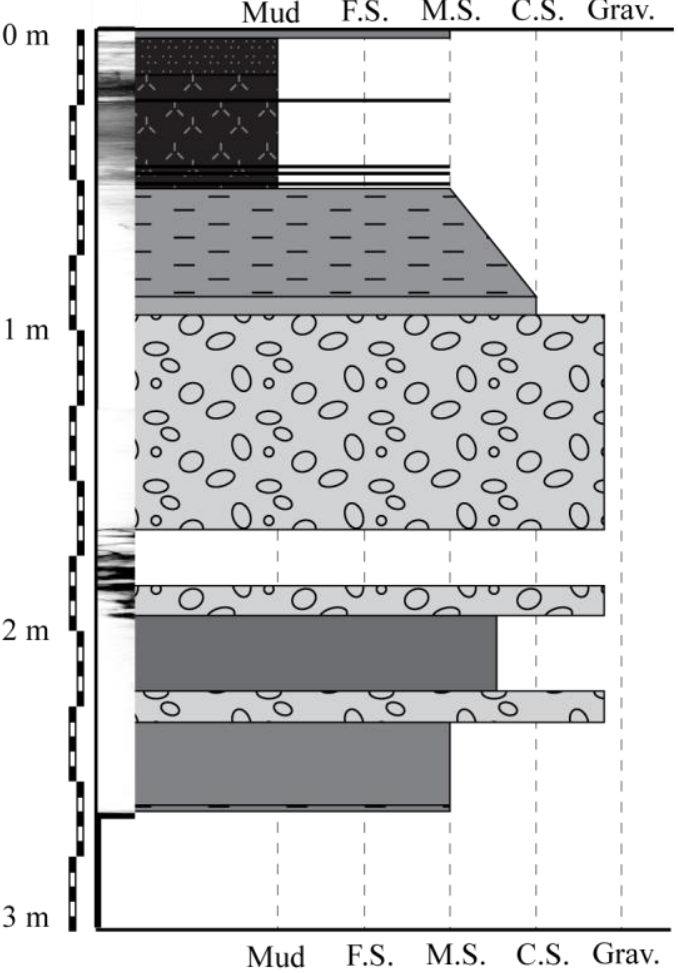

BHP4

Mud F.S. M.S. C.S. Grav.

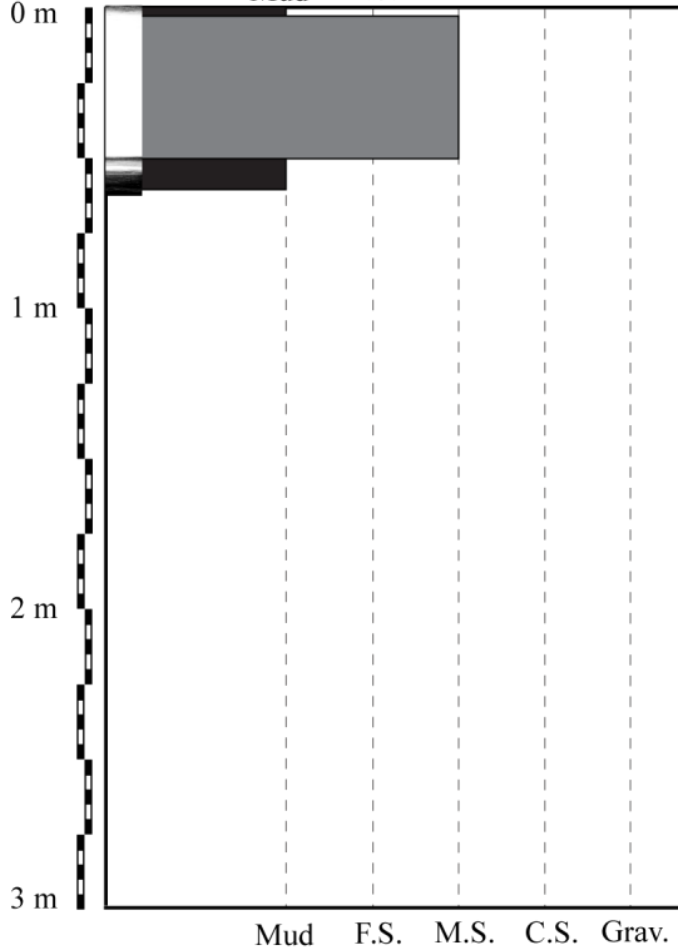




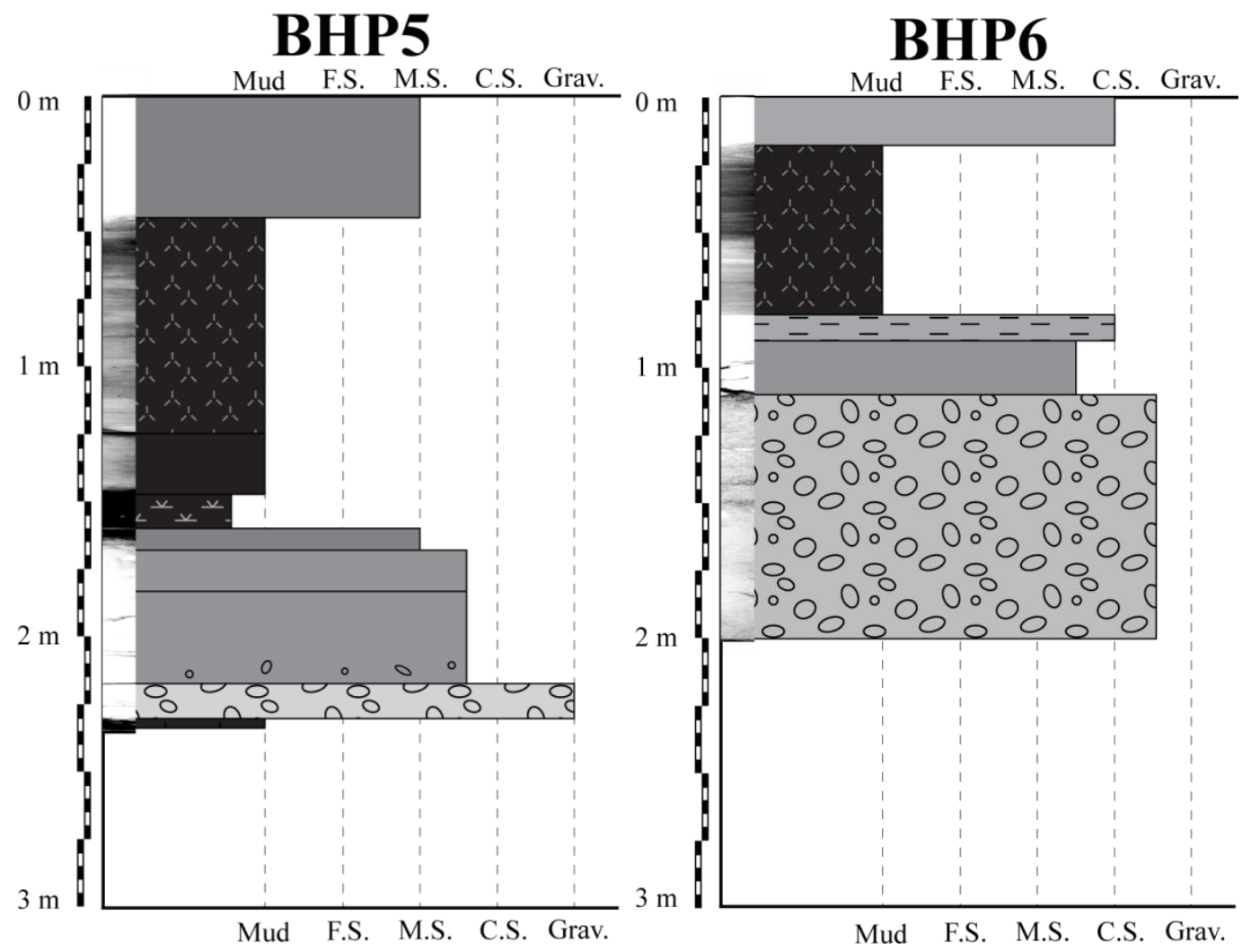

BHP7

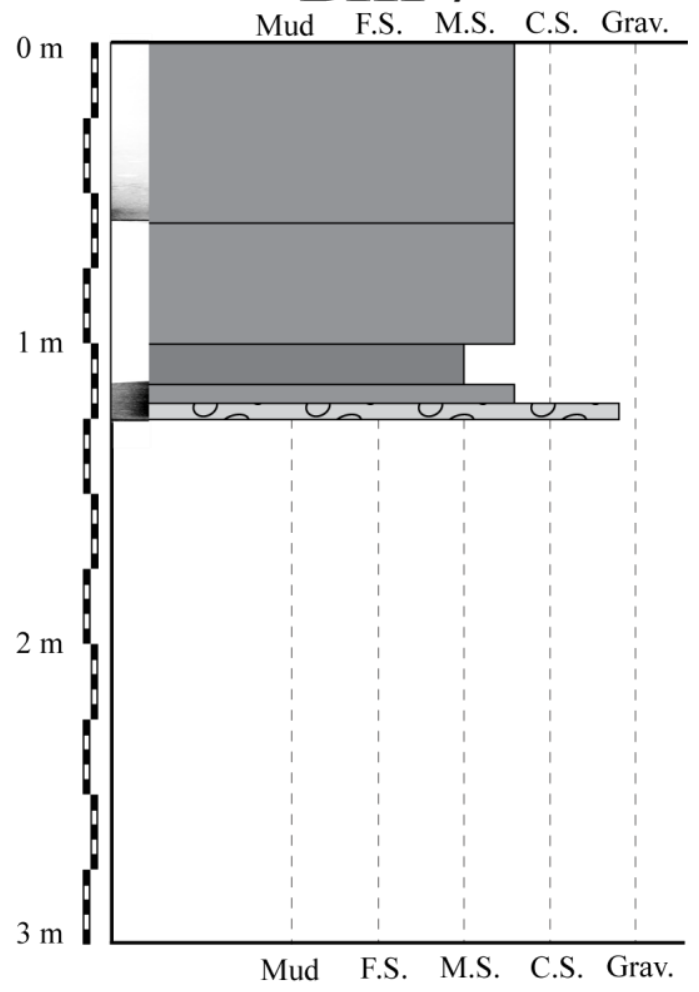




\section{BHP1}

\begin{tabular}{|c|c|c|c|c|c|}
\hline section & start & end & grain size & color & comments \\
\hline \multirow[t]{6}{*}{$1: 2$} & 0 & 48 & v.c. sand & $2.5 Y 4 / 3$ & $\begin{array}{l}\text { some granules concentrated pocket at } \\
\qquad 15-18 \mathrm{~cm}\end{array}$ \\
\hline & 48 & 53 & c. sand & $2.5 Y 3 / 3$ & poorly sorted with some mud \\
\hline & 53 & 82 & c. sand & $2.5 Y 3 / 2$ & $\begin{array}{l}\text { some mud mixed with sand at } 67- \\
68 \mathrm{~cm}\end{array}$ \\
\hline & \multirow{2}{*}{82} & \multirow{2}{*}{95} & silty sand & $2.5 Y 3 / 1$ & \multirow{2}{*}{$\begin{array}{l}\text { grading from silty sand to } \mathrm{m} \text {. sand; } \\
\text { some mud mixed throughout layer }\end{array}$} \\
\hline & & & m. sand & $2.5 Y 4 / 1$ & \\
\hline & 95 & 116 & clay & $2.5 Y 2.5 / 1$ & $\begin{array}{l}\text { mottled with decomposing organics; } \\
\text { end of core section }\end{array}$ \\
\hline \multirow[t]{8}{*}{$2: 2$} & 0 & 27 & clay & $2.5 Y 3 / 1$ & no visible organics \\
\hline & 27 & 31 & sandy clay & $2.5 Y 3 / 1$ & $\begin{array}{l}\text { transition zone to sand layer starting } \\
\text { at } 36 \mathrm{~cm}\end{array}$ \\
\hline & 31 & 36 & clayey sand & $2.5 Y 3 / 2$ & $\begin{array}{l}\text { transition zone to sand layer starting } \\
\text { at } 36 \mathrm{~cm}\end{array}$ \\
\hline & 36 & 78 & m./c. sand & $5 Y 4 / 2$ & $\begin{array}{c}\text { clayey sand layer at } 40-41 \mathrm{~cm} \text {, less } \\
\text { distinct one at } 43 \mathrm{~cm}\end{array}$ \\
\hline & 78 & 87 & c. sand & $5 Y 4 / 2$ & $\begin{array}{c}\text { some granules and pebbles; small gab } \\
\text { of } 1 \mathrm{~cm} \text { at } 83.5-84.5 \mathrm{~cm}\end{array}$ \\
\hline & 87 & 88.5 & silty f. sand & $2.5 Y 3 / 2$ & $\begin{array}{c}\text { more clay at top of layer, more sand at } \\
\text { bottom }\end{array}$ \\
\hline & 88.5 & 93 & m. sand & $2.5 Y 4 / 3$ & $\begin{array}{l}\text { fine sand grades from top; break in } \\
\text { core of } 1 \mathrm{~cm} \text { at } 91-92 \mathrm{~cm}\end{array}$ \\
\hline & 93 & 105 & v.c. sand & $2.5 Y 3 / 3$ & $\begin{array}{l}\text { some granules and pebbles; bottom of } \\
\text { core }\end{array}$ \\
\hline
\end{tabular}




\section{BHP2}

\begin{tabular}{|c|c|c|c|c|c|}
\hline section & start & end & grain size & color & comments \\
\hline \multirow[t]{6}{*}{$1: 2$} & 0 & 3.5 & m. sand & $2.5 Y 4 / 4$ & $\begin{array}{c}\text { sharp contact sharp with underlying } \\
\text { layer }\end{array}$ \\
\hline & 3.5 & 14 & m. sandy silt & $2.5 Y 3 / 1$ & $\begin{array}{c}7-8 \mathrm{~cm} \text { is sandy lens similar to } 0- \\
3.5 \mathrm{~cm} \text {; gradational contact with } \\
\text { underlying layer }\end{array}$ \\
\hline & 14 & 53 & silty clay & $5 Y 2.5 / 1$ & $\begin{array}{l}\text { mottled with decomposing organics } \\
(7.5 Y R 4 / 6) \text {; sand lenses at } 23,46, \\
48,51 \mathrm{~cm} \text {; gradational transition to } \\
\text { underlying layer starts at } 53 \mathrm{~cm}\end{array}$ \\
\hline & 53 & 88 & \multicolumn{2}{|c|}{ see comments } & $\begin{array}{l}\text { m. silty sand (10YR3/3) with some } \\
\text { organics to silty c. sand }(2.5 \mathrm{Y} 3 / 2) \text {; } \\
\text { transition zone, sharp color } \\
\text { transition to underlying layer }\end{array}$ \\
\hline & 88 & 94 & c. sand & $2.5 Y 4 / 1$ & gradation to underlying layer \\
\hline & 94 & 126 & vc sand/granular & $2.5 Y 4 / 2$ & $\begin{array}{c}\text { end of core; pebbles }(1-2 \mathrm{~cm}) \text { from } \\
120-126 \mathrm{~cm}\end{array}$ \\
\hline \multirow[t]{6}{*}{$2: 2$} & 0 & 40 & vc sand/granular & $2.5 Y 4 / 2$ & $\begin{array}{c}\text { continuation of above layer; some } \\
\text { pebbles throughout }\end{array}$ \\
\hline & 40 & 70 & \multicolumn{2}{|c|}{ see comments } & $\begin{array}{c}\text { same as layer above; gap in core, } \\
\text { looks like material fell out of bottom } \\
\text { of core and bottom shifted down } \\
\text { about } 20 \mathrm{~cm}\end{array}$ \\
\hline & 70 & 95 & $\mathrm{~m} / \mathrm{c}$ sand & 10YR3/4 & \\
\hline & 95 & 105 & vc sand/granular & 10YR3/6 & $\begin{array}{c}\text { some pebbles; fairly sharp contacts } \\
\text { above and below }\end{array}$ \\
\hline & 105 & 131 & m. sand & $2.5 Y 4 / 4$ & \\
\hline & 131 & 134 & \multicolumn{2}{|c|}{ see comments } & $\begin{array}{l}\text { m. sand from above mottled with } \\
\text { clay }(2.5 Y 3 / 1) \text {; not a distinct clay } \\
\text { layer; clay is mixed with m. sand and } \\
\text { in discrete globs; end of core }\end{array}$ \\
\hline
\end{tabular}

\section{BHP3}

\begin{tabular}{|c|c|c|c|c|c|}
\hline section & start & end & grain size & color & comments \\
\hline $1: 1$ & 0 & 69 & m. sand & $10 Y R 6 / 3$ & entire core is one unit \\
\hline
\end{tabular}


BHP4

\begin{tabular}{|c|c|c|c|c|c|}
\hline section & start & end & grain size & color & comments \\
\hline $1: 1$ & 0 & 2 & clay & $2.5 Y 3 / 2$ & modern pond sediments \\
\hline & 2 & 49 & m. sand & $2.5 Y 4 / 3$ & $\begin{array}{c}\text { rusty color at bottom starting at } \\
\text { about 42cm (7.5YR4/6) }\end{array}$ \\
\hline & 49 & 60 & silty clay & $2.5 Y 3 / 1$ & $\begin{array}{c}\text { some decomposing organics; end of } \\
\text { core }\end{array}$ \\
\hline
\end{tabular}

\section{BHP5}

\begin{tabular}{|c|c|c|c|c|c|}
\hline section & start & end & grain size & color & comments \\
\hline \multirow[t]{3}{*}{ 1:2 } & 0 & 1 & clay & $2.5 Y 3 / 2$ & modern pond sediments, loose mud \\
\hline & 1 & 44 & m. sand & $2.5 Y 4 / 4$ & $\begin{array}{l}\text { sharp diagonal contact } 40-48 \mathrm{~cm} \text { at } \\
45^{\circ} \text { angle }\end{array}$ \\
\hline & 44 & 125 & clay & $2.5 Y 3 / 2$ & $\begin{array}{l}\text { end of section; mottled with some } \\
\text { decomposing organics, some plant } \\
\text { fragments visible }\end{array}$ \\
\hline \multirow[t]{7}{*}{$2: 2$} & 0 & 22 & clay & $5 Y 3 / 2$ & $\begin{array}{l}\text { no apparent organics but otherwise } \\
\text { appears the same as above layer }\end{array}$ \\
\hline & 22 & 34 & peat & 10YR2/1 & some clay mixed in at top \\
\hline & 34 & 43 & m. sand & 10YR2/1 & $\begin{array}{l}\text { peaty sand, grading to less peat at } \\
\text { bottom }\end{array}$ \\
\hline & 43 & 59 & m./c. sand & $2.5 Y 4 / 2$ & poorly sorted \\
\hline & 59 & 92 & silty $\mathrm{m} . / \mathrm{c}$. sand & 10YR2/2 & $\begin{array}{c}\text { very poorly sorted; some plant } \\
\text { fragments mixed in; some pebbles } \\
\text { towards bottom; gap in core from } 70- \\
72 \mathrm{~cm}\end{array}$ \\
\hline & 92 & 106 & v.c. sand & 10YR3/3 & $\begin{array}{c}\text { also with granules and pebbles; } \\
\text { similar to above but with coarser } \\
\text { material; some pebbles }>1.5 \mathrm{~cm} \text { in } \\
\text { diameter }\end{array}$ \\
\hline & 106 & 109 & clay & 10YR3/1 & some small plant fragments \\
\hline
\end{tabular}


BHP6

\begin{tabular}{|c|c|c|c|c|c|}
\hline section & start & end & grain size & color & comments \\
\hline \multirow[t]{5}{*}{$1: 2$} & 0 & 17 & c. sand & $2.5 Y 4 / 4$ & sharp contact with layer below \\
\hline & 17 & 82 & clay & 10YR2/1 & $\begin{array}{l}\text { mottled with lots of organics; sharp } \\
\text { contact with layers above and below }\end{array}$ \\
\hline & \multirow{2}{*}{82} & \multirow{2}{*}{89} & clayey c. sand & 10YR2/1 & \multirow{2}{*}{$\begin{array}{l}\text { Transition zone; mostly sand with } \\
\text { mud mixed in at top }\end{array}$} \\
\hline & & & c. sand & $2.5 Y 3 / 1$ & \\
\hline & 89 & 111 & $\mathrm{~m} / \mathrm{c}$ sand & $2.5 Y 5 / 3$ & end of core section \\
\hline $2: 2$ & 0 & 90 & v.c. sand & $2.5 Y 5 / 4$ & $\begin{array}{l}\text { granules and some pebbles; end of } \\
\text { core }\end{array}$ \\
\hline
\end{tabular}

BHP7

\begin{tabular}{|c|c|c|c|c|c|}
\hline $\begin{array}{l}\text { secti } \\
\text { on }\end{array}$ & start & end & grain size & color & comments \\
\hline $1: 2$ & 0 & 60 & m./c. sand & $2.5 Y 5 / 3$ & $\begin{array}{l}\text { entire section is one unit, sand was } \\
\text { flattened out at bottom of core so } \\
\text { depth is estimated }\end{array}$ \\
\hline $2: 2$ & 0 & 41 & m./c. sand & 10YR5/3 & $\begin{array}{c}\text { contact at a diagonal from } 36-45 \mathrm{~cm} \text {; } \\
\text { continues from last layer }\end{array}$ \\
\hline & 41 & 54 & m. sand & 10YR3/4 & $\begin{array}{c}\text { contact diagonal from } 49-56 \mathrm{~cm} ; \\
\text { some rust-like staining especially in } \\
\text { the bottom half }\end{array}$ \\
\hline & 54 & 60 & m./c. sand & 10YR5/3 & top contact at a diagonal \\
\hline & 60 & 66 & v.c. sand/grav. & 10YR4/3 & mud mixed in at bottom; end of core \\
\hline
\end{tabular}




\section{A.3. Long Cove Pond Cores}

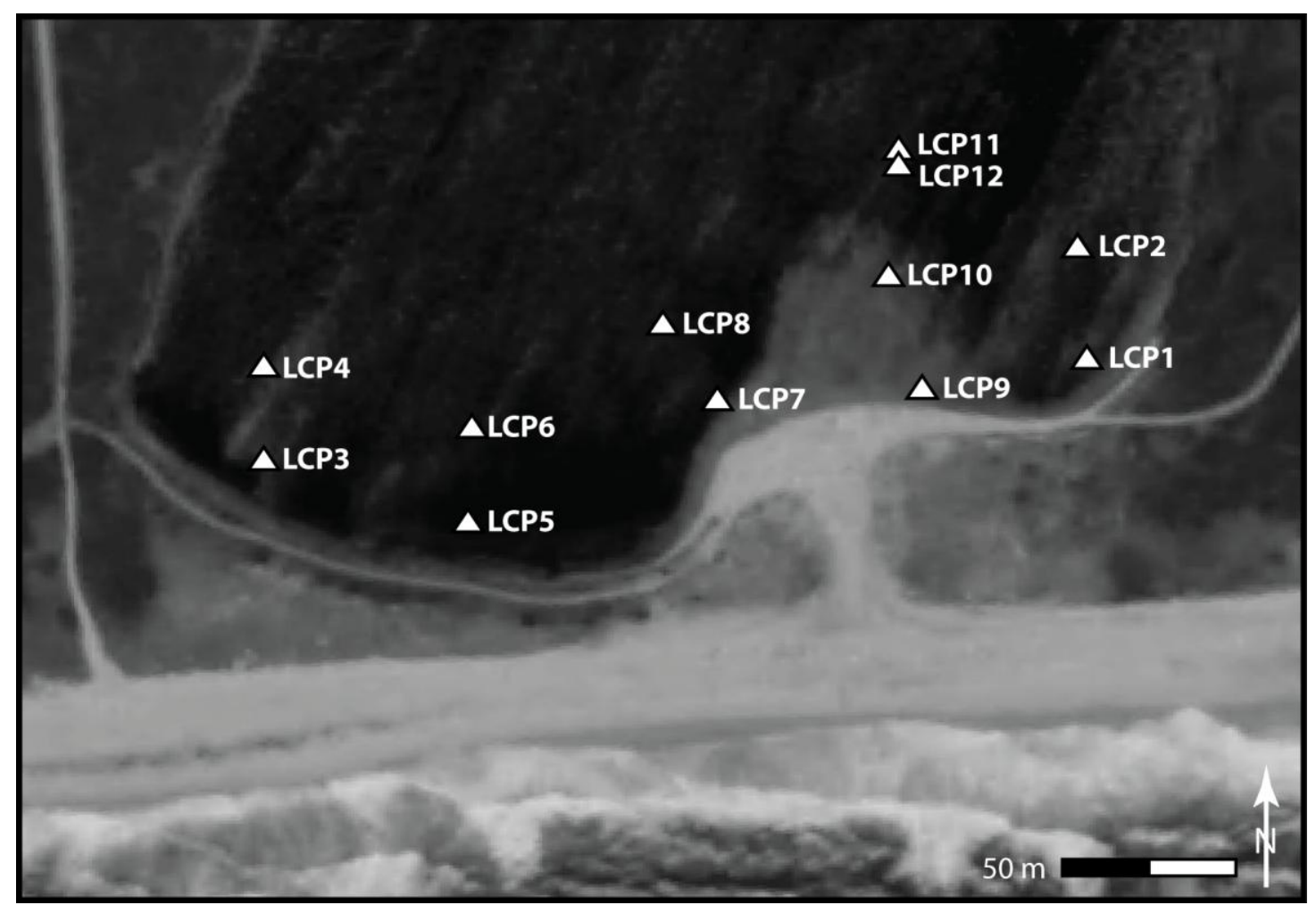

The above figure indicated core locations at Long Cove Pond. The following graphic core logs, radiographs, and verbal descriptions follow the same explanation as detailed in section A.1. 

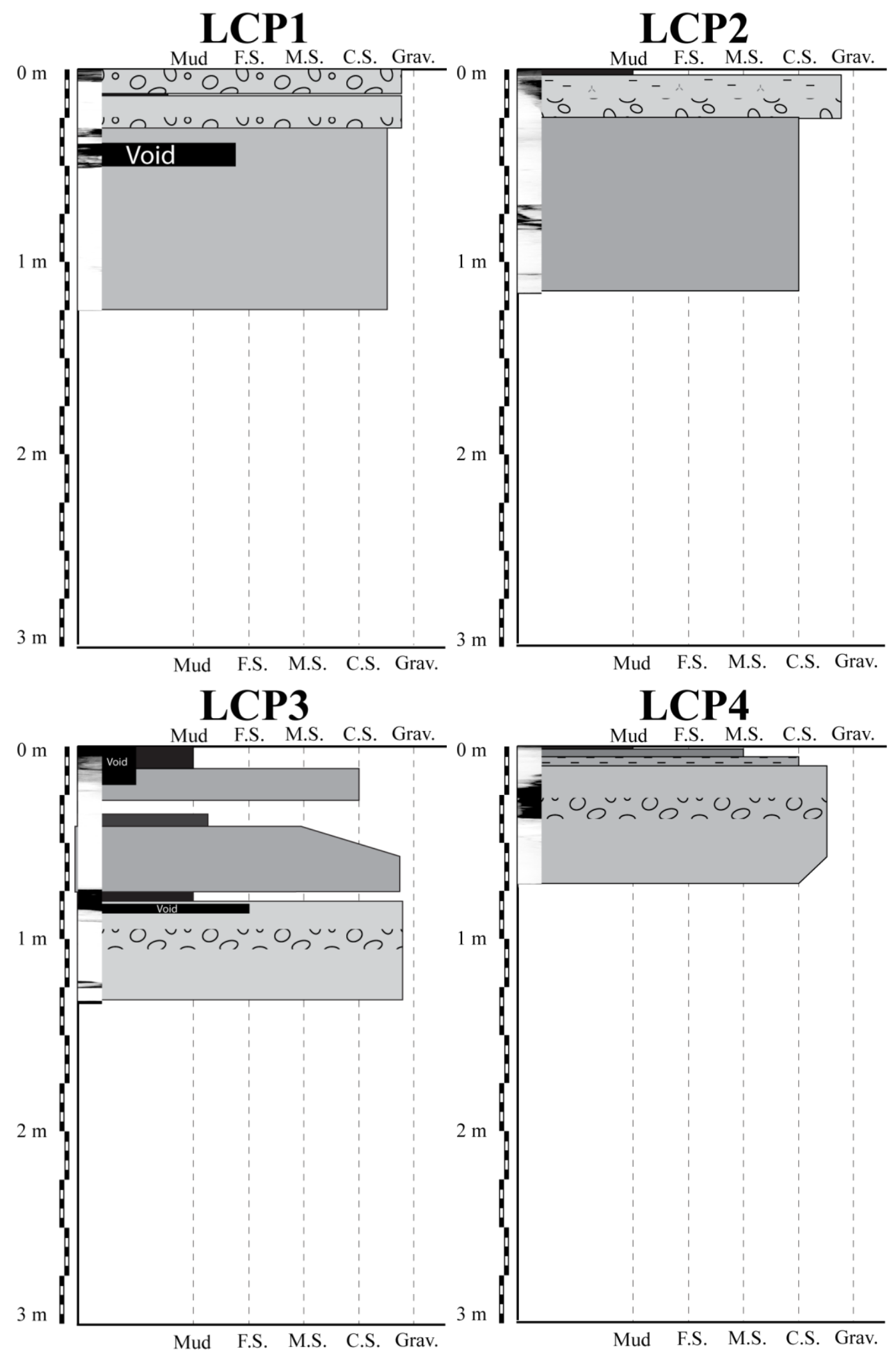


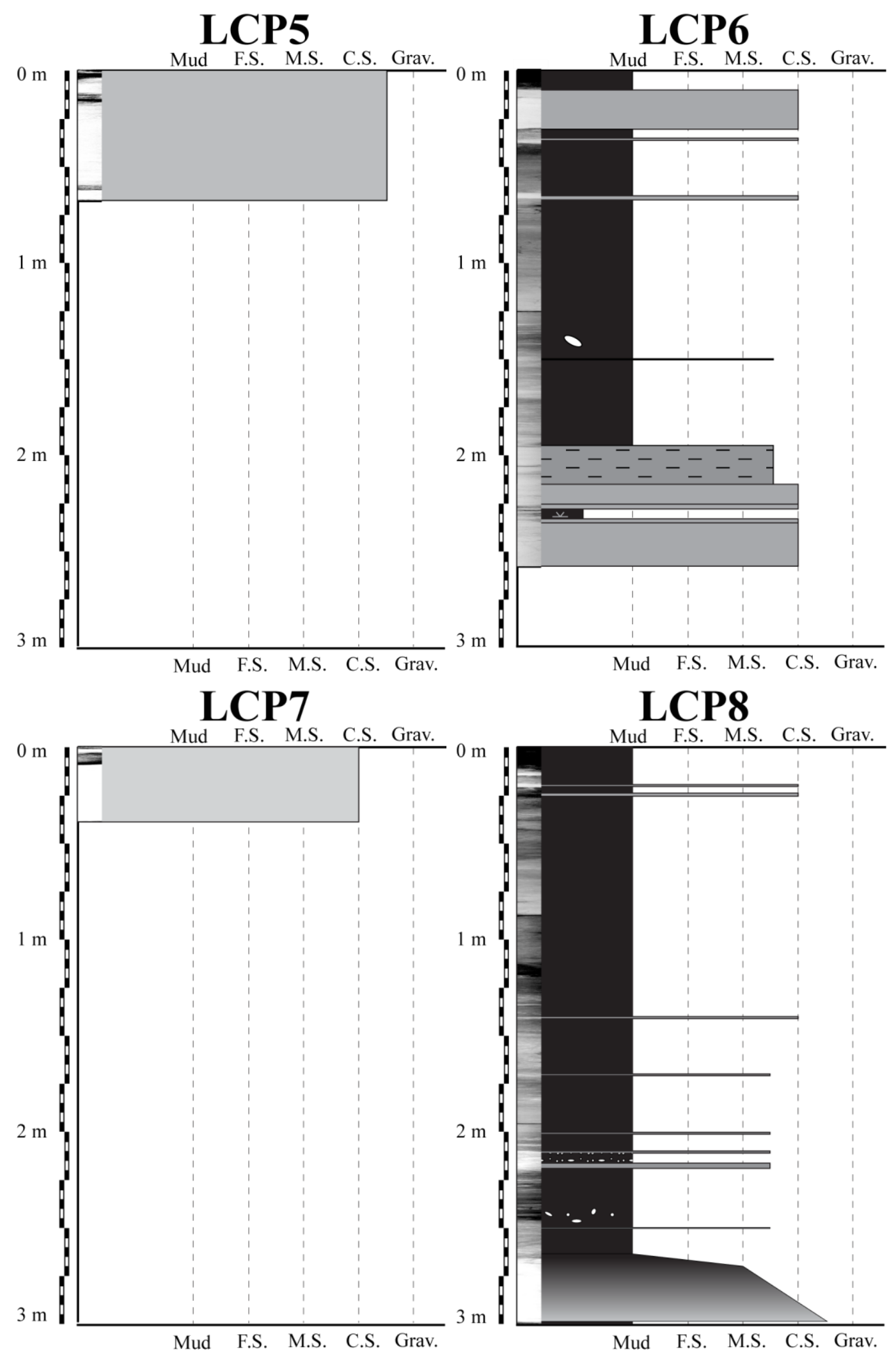



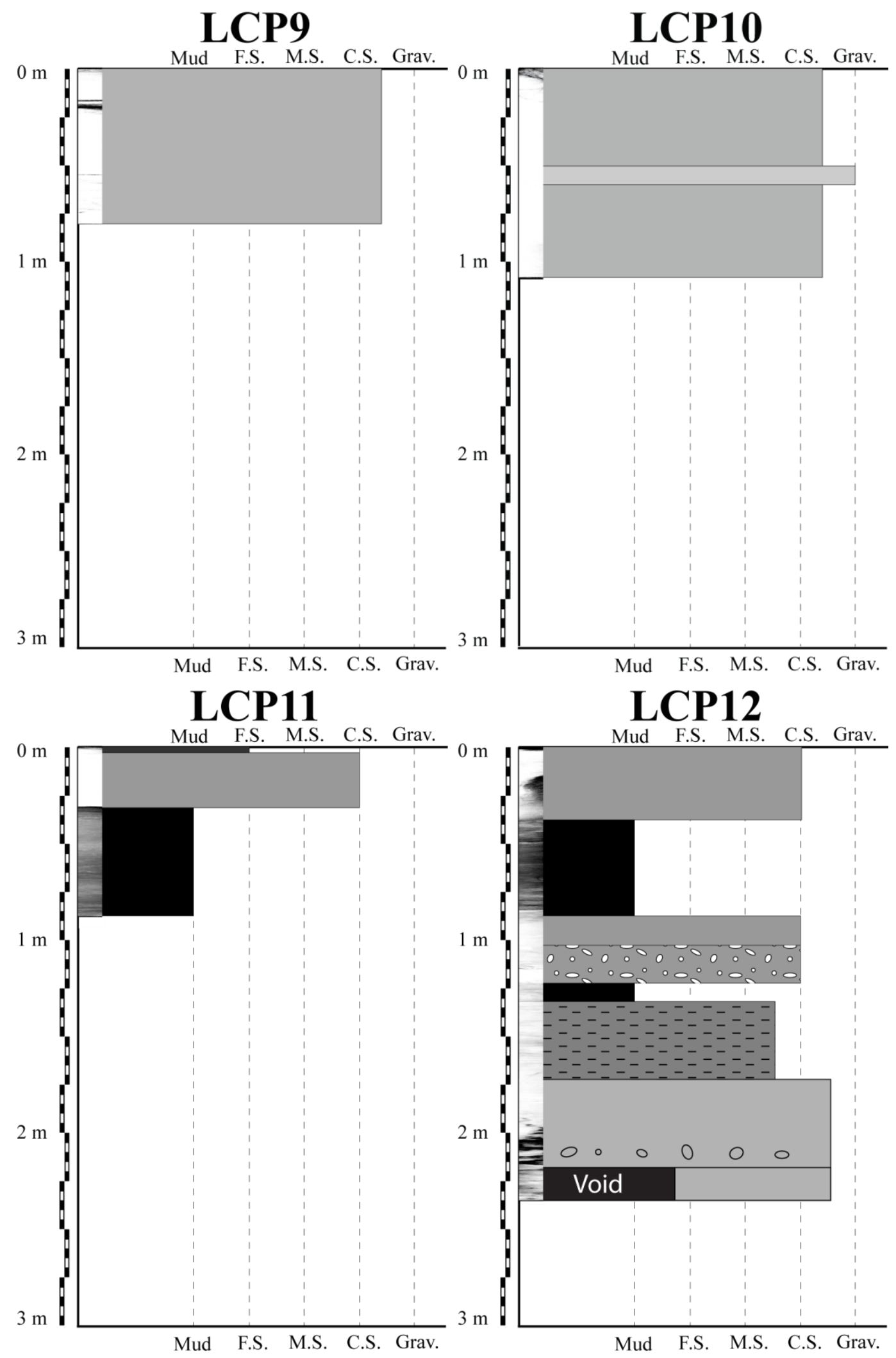
LCP1

\begin{tabular}{|c|c|c|c|c|c|}
\hline section & start & end & grain size & color & comments \\
\hline $1: 1$ & 0 & 0 & $\mathrm{n} / \mathrm{a}$ & $\mathrm{n} / \mathrm{a}$ & $\begin{array}{c}\text { thin layer of modern org. at } \\
\text { top }\end{array}$ \\
\hline & 0 & 13 & vc sand/ gran & $2.5 Y 5 / 2$ & pebbles also \\
\hline & 13 & 14 & peaty mud & $10 Y R 2 / 1$ & volor from above until $16 \mathrm{~cm}$, \\
& 14 & 30 & vc to gran to pebb & $10 Y R 4 / 3$ & $\begin{array}{c}\text { cobbles mixed in at } 25-30 \mathrm{~cm} \\
\text { pebs }\end{array}$ \\
\hline & 30 & 125 & vc sand & 10YR4/4 & $\begin{array}{c}\text { sed missing } 68-116 \mathrm{~cm} \text { (about } \\
1 / 2)\end{array}$ \\
\hline
\end{tabular}

LCP2

\begin{tabular}{|c|c|c|c|c|c|}
\hline $\begin{array}{c}\text { sectio } \\
n\end{array}$ & start & end & grain size & color & comments \\
\hline \multirow[t]{2}{*}{$1: 2$} & 0 & 3 & silt & 10YR2/1 & $\begin{array}{l}\text { top is deformed a bit, sand } \\
\text { mixed }\end{array}$ \\
\hline & 3 & 61 & vc sand/gran & 10YR2/2 & $\begin{array}{c}8 \times 3 \mathrm{~cm} \text { cobble at } 17-22 \mathrm{~cm}, \\
\text { woods at } 9-10 \mathrm{~cm} \text {, some mud } \\
\text { mixed in at } 6-11 \mathrm{~cm} \text {, pebbles } \\
\text { mixed in } 15-\text { end }\end{array}$ \\
\hline $2: 2$ & 0 & 55 & c sand & $2.5 Y 4 / 3$ & $\begin{array}{l}\text { some pebbles, sand is } \\
\text { deformed at top of core so } \\
\text { depth is approximate }\end{array}$ \\
\hline
\end{tabular}


LCP3

\begin{tabular}{|c|c|c|c|c|c|}
\hline section & start & end & grain size & color & comments \\
\hline \multicolumn{6}{|c|}{$* * *$ top of core is deformed, actual good depth start at $\sim 36 \mathrm{~cm}$ depth $* * *$} \\
\hline \multirow[t]{5}{*}{$1: 2$} & 0 & 11 & silt & $2.5 Y 3 / 2$ & $\begin{array}{l}\text { silt is loose, actual thickness } \\
\text { is about } 1 / 2\end{array}$ \\
\hline & 11 & 27 & c sand & $2.5 Y 4 / 3$ & $\begin{array}{l}\text { gap on side, actual } \\
\text { thickness is to } \sim 21-22 \mathrm{~cm}\end{array}$ \\
\hline & 27 & 36 & $\mathrm{n} / \mathrm{a}$ & $\mathrm{n} / \mathrm{a}$ & gap in core \\
\hline & 36 & 41 & silty $f$ sand & $2.5 Y 3 / 2$ & poorly sorted \\
\hline & 41 & 76 & vc sand/gran & $2.5 Y 5 / 2$ & $\begin{array}{l}\text { goes from } \mathrm{m} \text { sand at top to } \\
\text { vc sand/granular at } 56 \mathrm{~cm}\end{array}$ \\
\hline \multirow[t]{2}{*}{$2: 2$} & 0 & 3 & silty clay & $2.5 Y 2.5 / 1$ & \\
\hline & 3 & 55 & vc sand/gran & $2.5 Y 4 / 3$ & $\begin{array}{c}\text { some granular/pebbles } \\
\text { mixed in } 20-35 \mathrm{~cm} ; 12-17 \mathrm{~cm} \\
\text { some gaps, } 1 / 2 \text { full }\end{array}$ \\
\hline
\end{tabular}

LCP4

\begin{tabular}{|c|c|c|c|c|c|}
\hline section & start & end & grain size & color & comments \\
\hline \multirow[t]{4}{*}{$1: 1$} & 0 & 2 & silt & $2.5 Y 3 / 2$ & \\
\hline & 2 & 5 & m sand & $2.5 Y 4 / 2$ & chunk missing from side \\
\hline & 5 & 10 & c sand/mud & $2.5 Y 3 / 1$ & very muddy \\
\hline & 10 & 72 & vc sand & & $\begin{array}{l}\text { grades to c sand at bottom } \\
\text { starting at } 52 \mathrm{~cm} \text {, some } \\
\text { voids and pebbles } 20-38 \mathrm{~cm}\end{array}$ \\
\hline
\end{tabular}

\section{LCP5}

\begin{tabular}{|c|c|c|c|c|c|}
\hline section & start & end & grain size & color & comments \\
\hline $1: 1$ & 0 & 67 & vc sand & $2.5 Y 5 / 3$ & $\begin{array}{c}\text { partially decomposed grass } \\
\text { at } 60-61 \mathrm{~cm} \text {, may be } \\
\text { modern that was pulled } \\
\text { down }\end{array}$ \\
\hline
\end{tabular}


LCP6

\begin{tabular}{|c|c|c|c|c|c|}
\hline section & start & end & grain size & color & comments \\
\hline $1: 2$ & 0 & 11 & silt & $2.5 Y 3 / 2$ & silt is very loose \\
\hline & 11 & 31 & c. sand & 10YR3/4 & $\begin{array}{c}\text { muddier layer (mixed with } \\
\text { sand) at } 14 \mathrm{~cm}, \\
\text { laminations) }\end{array}$ \\
\hline & 31 & 124 & clay (and silt) & $2.5 Y 3 / 1$ & end of section \\
\hline & 64 & 67 & c. sand & $10 Y R 3 / 3$ & some mud mixed in \\
\hline & 36 & 37.5 & muddy c. sand & 10YR3/3 & $\begin{array}{c}\text { very muddy, not as distinct } \\
\text { as layer at } 64-67 \mathrm{~cm}\end{array}$ \\
\hline \multirow[t]{9}{*}{$2: 2$} & 0 & 71 & clay (and silt) & $2.5 Y 3 / 1$ & $\begin{array}{l}\text { shell at } 15 \mathrm{~cm} \text { (should be in } \\
\text { archive half), small m/c } \\
\text { sand layer with mud mixed } \\
\text { in at } 26-27 \mathrm{~cm}\end{array}$ \\
\hline & 71 & 90 & $\mathrm{~m} / \mathrm{c}$ sand & $5 Y 2.5 / 2$ & $\begin{array}{l}\text { very muddy, esp. at } 86- \\
87 \mathrm{~cm}\end{array}$ \\
\hline & \multirow{2}{*}{90} & \multirow{2}{*}{100} & \multirow{2}{*}{ c sand } & $5 Y 2.5 / 2$ & \multirow{2}{*}{ muddier at top } \\
\hline & & & & $5 Y 5 / 1$ & \\
\hline & 100 & 103.5 & c sand & $2.5 Y 2.5 / 1$ & some mud mixed in \\
\hline & 103.5 & 108 & PEAT & gley1 2.5/N & \\
\hline & 108 & 110.5 & c sand & $2.5 Y 2.5 / 1$ & \\
\hline & \multirow{2}{*}{110.5} & \multirow{2}{*}{134} & \multirow{2}{*}{ muddy c. sand } & gley1 $2.5 / \mathrm{N}$ & \multirow{2}{*}{$\begin{array}{l}\text { peat mixed at top to } \\
\sim 116 \mathrm{~cm} \text {, remains muddy to } \\
\text { end }\end{array}$} \\
\hline & & & & $2.5 Y 3 / 2$ & \\
\hline
\end{tabular}

LCP7

\begin{tabular}{|c|c|c|c|c|c|}
\hline section & start & end & grain size & color & comments \\
\hline $1: 1$ & 0 & 39 & c sand & $2.5 Y 4 / 3$ & $\begin{array}{c}\text { whole core is one unit, gap } \\
\text { filled with foam } ~ 3-8 \mathrm{~cm}\end{array}$ \\
\hline
\end{tabular}




\section{LCP8}

\begin{tabular}{|c|c|c|c|c|c|}
\hline section & start & end & grain size & color & comments \\
\hline \multirow[t]{5}{*}{$1: 3$} & 0 & 18 & silt & $2.5 Y 3 / 2$ & loose silt \\
\hline & 18 & 19.5 & c sand & 10YR3/4 & \\
\hline & 19.5 & 24 & silt & $2.5 Y 3 / 2$ & loose silt \\
\hline & 24 & 26 & c sand & 10YR4/3 & \\
\hline & 26 & 88 & clay/silt & $5 Y 2.5 / 2$ & more compact than top \\
\hline \multirow[t]{5}{*}{$2: 3$} & 0 & 51 & clay & $5 Y 2.5 .5 / 2$ & \\
\hline & 51 & 52 & clayey m/c sand & $5 Y 2.5 / 2$ & $\begin{array}{l}\text { thin sand layer with mud } \\
\text { mixed in above and below }\end{array}$ \\
\hline & 52 & 81.5 & clay & $5 Y 2.5 / 2$ & \\
\hline & 81.5 & 83 & clayey $\mathrm{m} / \mathrm{c}$ sand & $5 Y 2.5 / 2$ & mud mixed in \\
\hline & 83 & 106 & clay & $5 Y 2.5 / 2$ & $\begin{array}{c}\text { possible very thin } \mathrm{m} / \mathrm{c} \text { sand } \\
\text { layer at } 93 \mathrm{~cm}\end{array}$ \\
\hline \multirow[t]{11}{*}{$3: 3$} & 0 & 7.5 & clay & $5 Y 2.5 / 2$ & \\
\hline & 7.5 & 8 & clayey $\mathrm{m} / \mathrm{c}$ sand & $5 Y 2.5 / 2$ & thin sand layer \\
\hline & 8 & 15 & clay & $5 Y 2.5 / 2$ & \\
\hline & 15 & 15.5 & clayey $\mathrm{m} / \mathrm{c}$ sand & $5 Y 2.5 / 2$ & thin sand layer \\
\hline & 15.5 & 22.5 & clay & $5 Y 2.5 / 2$ & couple shell fragments \\
\hline & 22.5 & 25 & clayey $\mathrm{m} / \mathrm{c}$ sand & $5 Y 2.5 / 2$ & \\
\hline & 25 & 56 & clay & $5 Y 2.5 / 2$ & $\begin{array}{c}\text { Some shell fragments, large } \\
\text { shell pieces } 42-44 \mathrm{~cm}, \\
\text { whole shell at } 52 \mathrm{~cm}\end{array}$ \\
\hline & 56 & 57 & clayey $\mathrm{m} / \mathrm{c}$ sand & $5 Y 2.5 / 2$ & partial sand layer \\
\hline & 57 & 70 & clay & $5 Y 2.5 / 2$ & \\
\hline & 70 & 105 & $\begin{array}{l}\mathrm{m} \text { sand to vc sand } \\
\text { with pebbles }\end{array}$ & $5 Y 2.5 / 2$ & $\begin{array}{l}\text { coarsening down, clay } \\
\text { mixed into top until } \sim 78 \mathrm{~cm}\end{array}$ \\
\hline & 105 & 107 & clay & $5 Y 2.5 / 1$ & \\
\hline
\end{tabular}

LCP9

\begin{tabular}{|c|c|c|c|c|c|}
\hline section & start & end & grain size & color & comments \\
\hline $1: 1$ & 0 & 80 & c/vc sand & $2.5 Y 5 / 3$ & entire core is one unit \\
\hline
\end{tabular}

\section{LCP10}

\begin{tabular}{|c|c|c|c|c|c|}
\hline section & start & end & grain size & color & comments \\
\hline $1: 1$ & 0 & 107 & vc sand & $2.5 Y 5 / 3$ & $\begin{array}{c}\text { one unit, slightly coarser } \\
\text { (granular) at } 50-60 \mathrm{~cm}\end{array}$ \\
\hline
\end{tabular}


LCP11

\begin{tabular}{|c|c|c|c|c|c|}
\hline section & start & end & grain size & color & comments \\
\hline $1: 1$ & 0 & 3 & sand w/ silt & $2.5 Y 2.5 / 1$ & some mud mixed in \\
\hline & 3 & 31 & c sand & $2.5 Y 4 / 4$ & $\begin{array}{c}\text { mud mixed in until about } \\
7 \mathrm{~cm}\end{array}$ \\
\hline & 31 & 87 & clay/silt & $5 Y 2.5 / 2$ & \\
\hline
\end{tabular}

LCP12

\begin{tabular}{|c|c|c|c|c|c|}
\hline section & start & end & grain size & color & comments \\
\hline \multicolumn{6}{|c|}{$\begin{array}{l}\text { ***Core was on its side and mud moved up the side at the top. Depths are estimated until } \\
\qquad 50 \mathrm{~cm}^{* * *}\end{array}$} \\
\hline \multirow[t]{5}{*}{$1: 2$} & 0 & 37 & c sand* & $2.5 Y 4 / 3$ & $\begin{array}{l}*^{*} \text { mud up side, sand layer is } \\
\text { probably thinner }\end{array}$ \\
\hline & 37 & 88 & mud (clay) & $5 Y 2.5 / 1$ & \\
\hline & 88 & 103 & c sand & $2.5 Y 3 / 3$ & \\
\hline & 103 & 122 & c sand & gley1 3/N & shell hash \\
\hline & 122 & 131 & silt & $2.5 Y 3 / 2$ & \\
\hline \multirow[t]{3}{*}{$2: 2$} & 0 & 41 & $\mathrm{~m} / \mathrm{c}$ sand & gley1 $2.510 Y$ & very muddy, at least $50 \%$ \\
\hline & 41 & 86 & vc sand & $2.5 Y 5 / 2$ & some pebbles $72-77 \mathrm{~cm}$ \\
\hline & 86 & 103 & vc sand & $2.5 Y 5 / 2$ & $\begin{array}{l}\text { same as previous, but } 1 / 2 \\
\text { of sed is gone }\end{array}$ \\
\hline
\end{tabular}




\section{A.4. Edgartown Great Pond Cores}

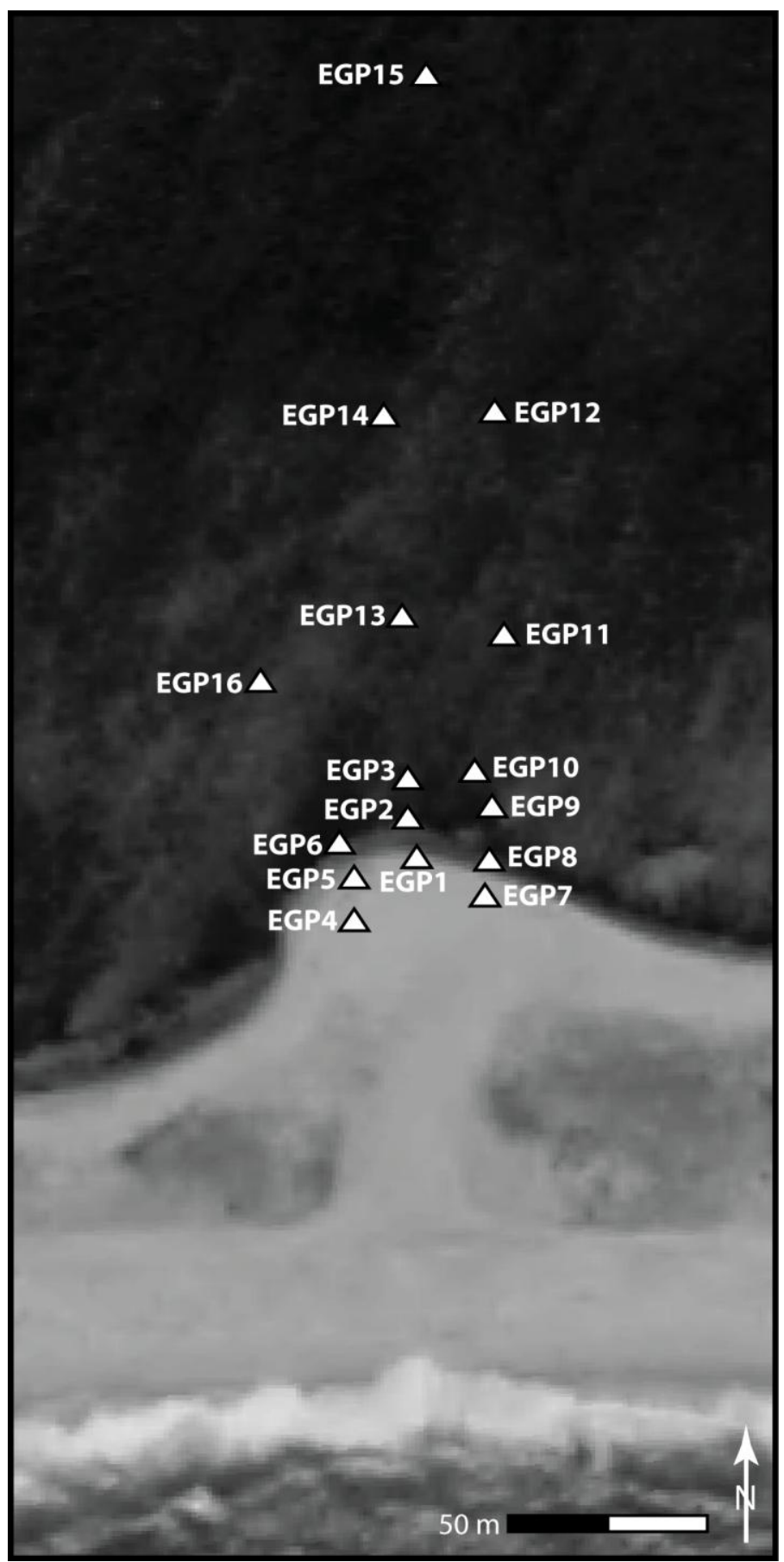

The above figure indicated core locations at Edgartown Great Pond. The following graphic core logs, radiographs, and verbal descriptions follow the same explanation as detailed in section A.1. 
EGP1

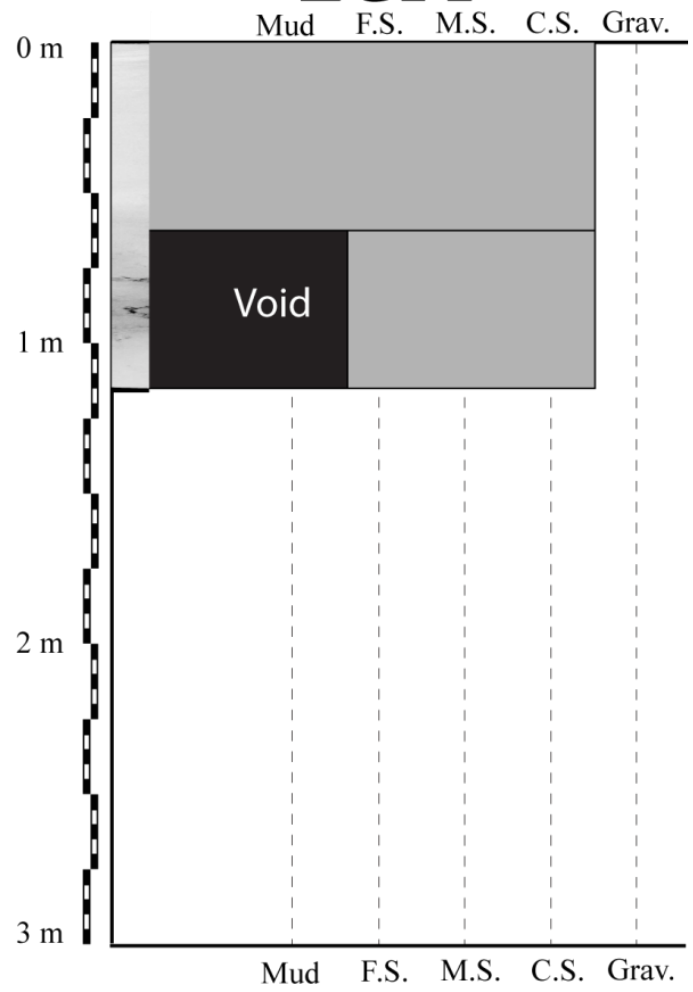

EGP3

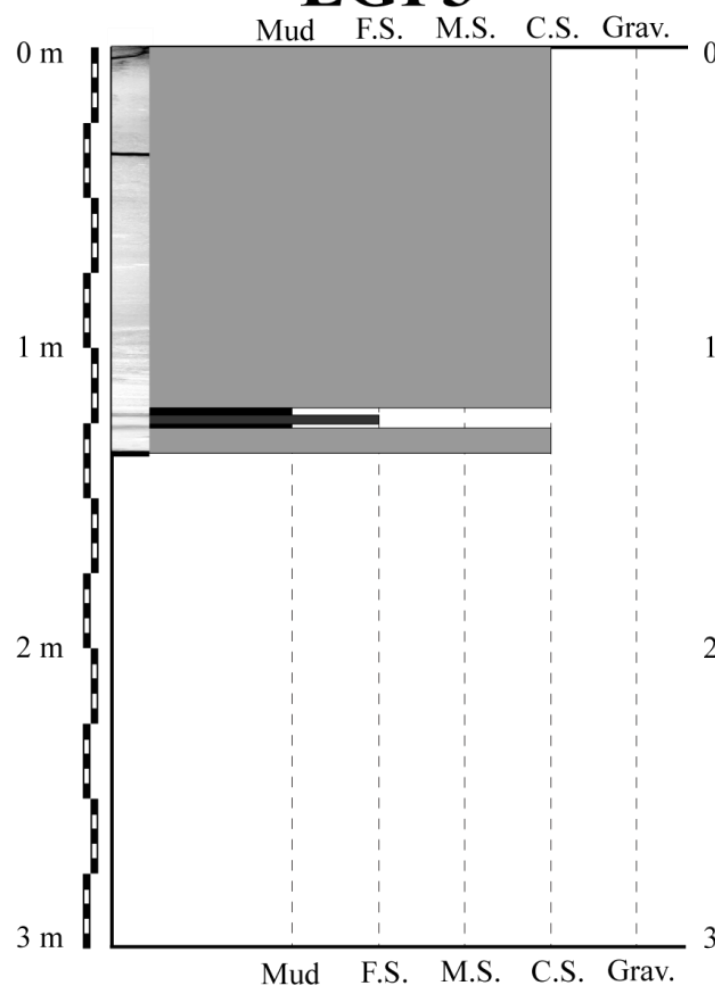

EGP2

Mud F.S. M.S. C.S. Grav.

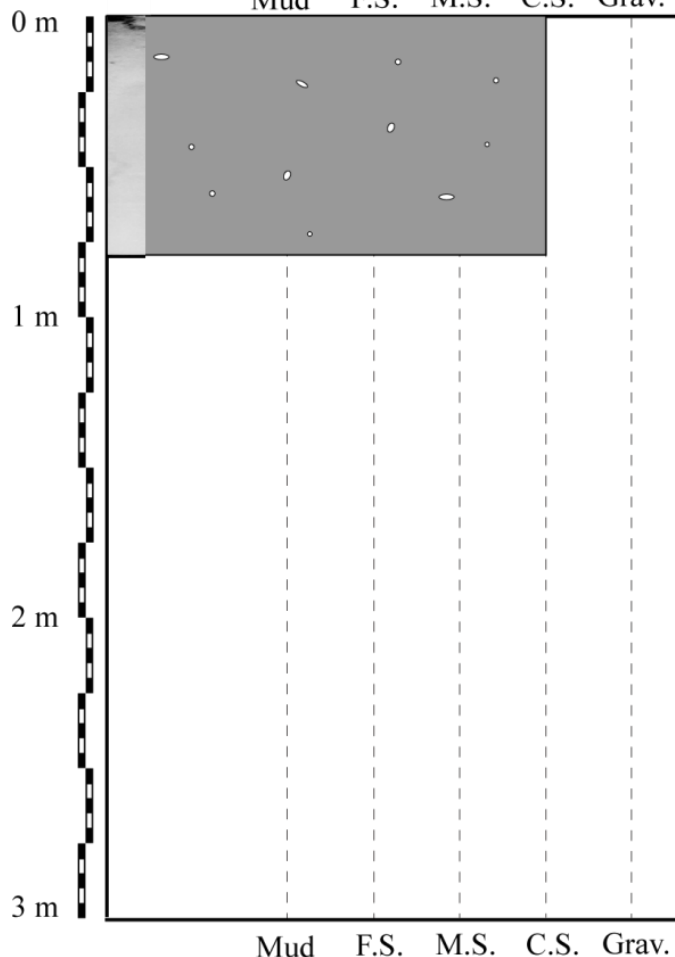

EGP4

Mud F.S. M.S. C.S. Grav.

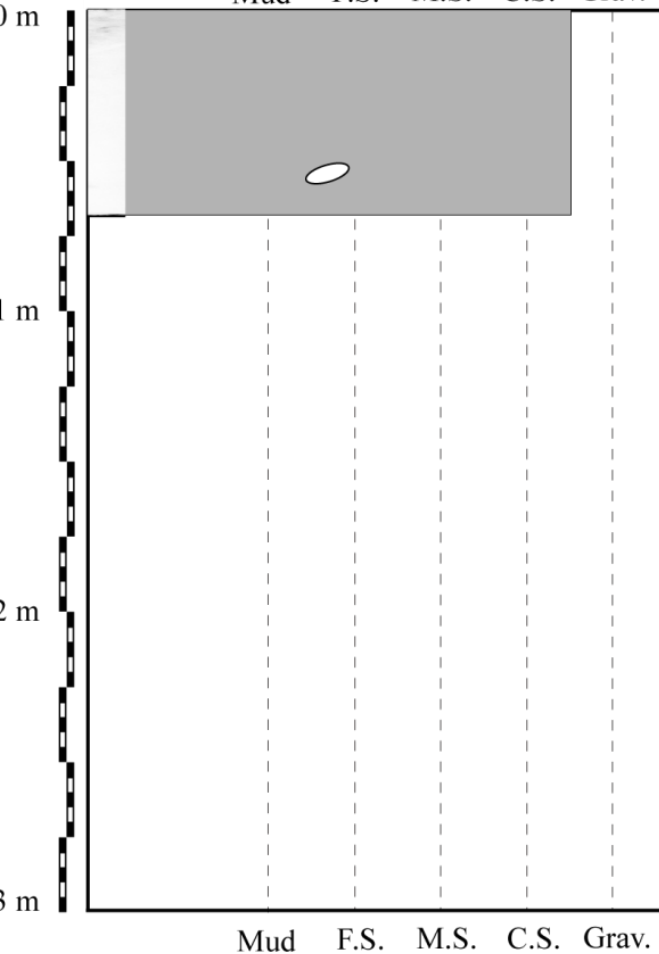


EGP5

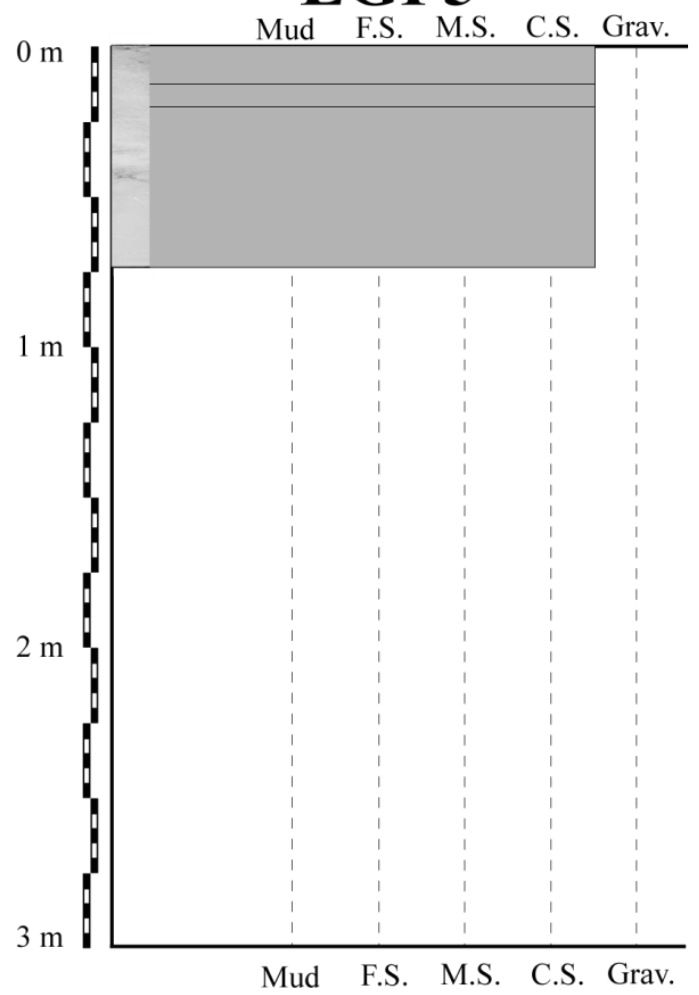

EGP7

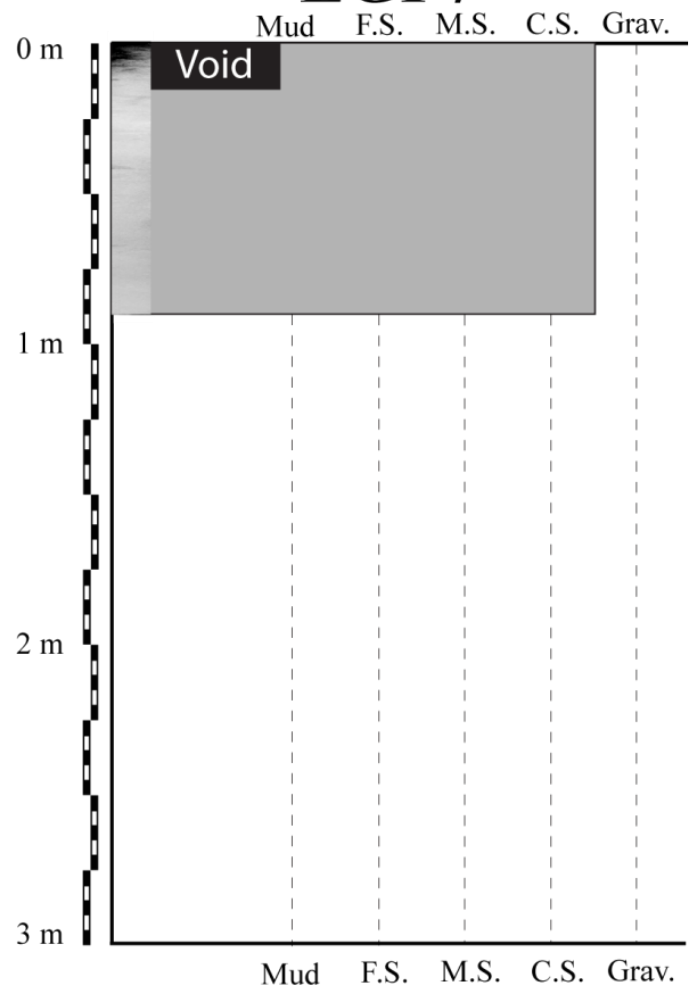

EGP6

Mud F.S. M.S. C.S. Grav.

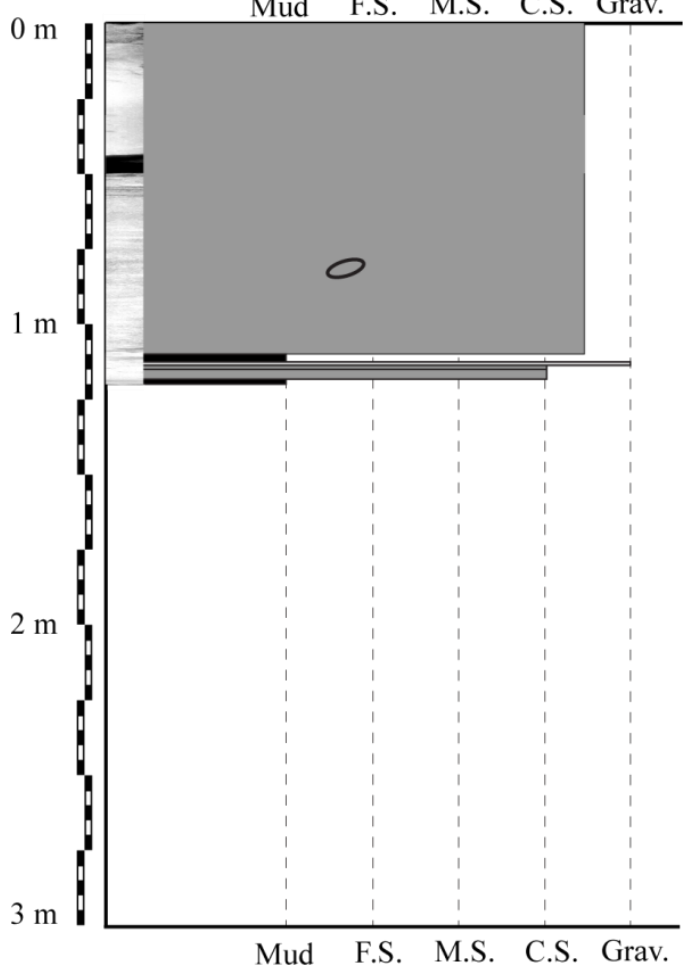

EGP8

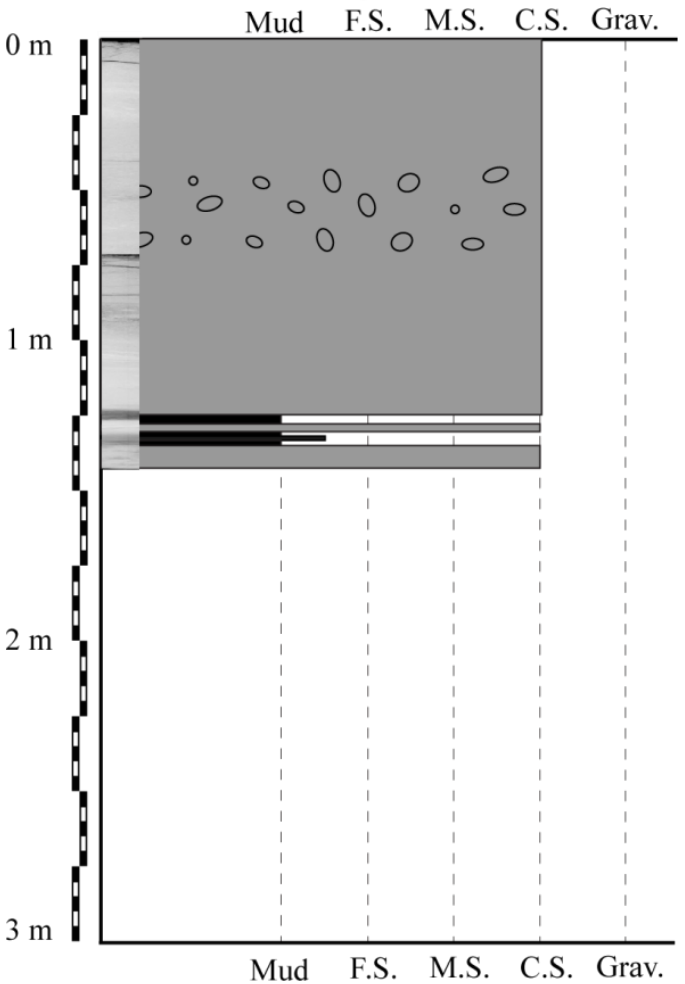



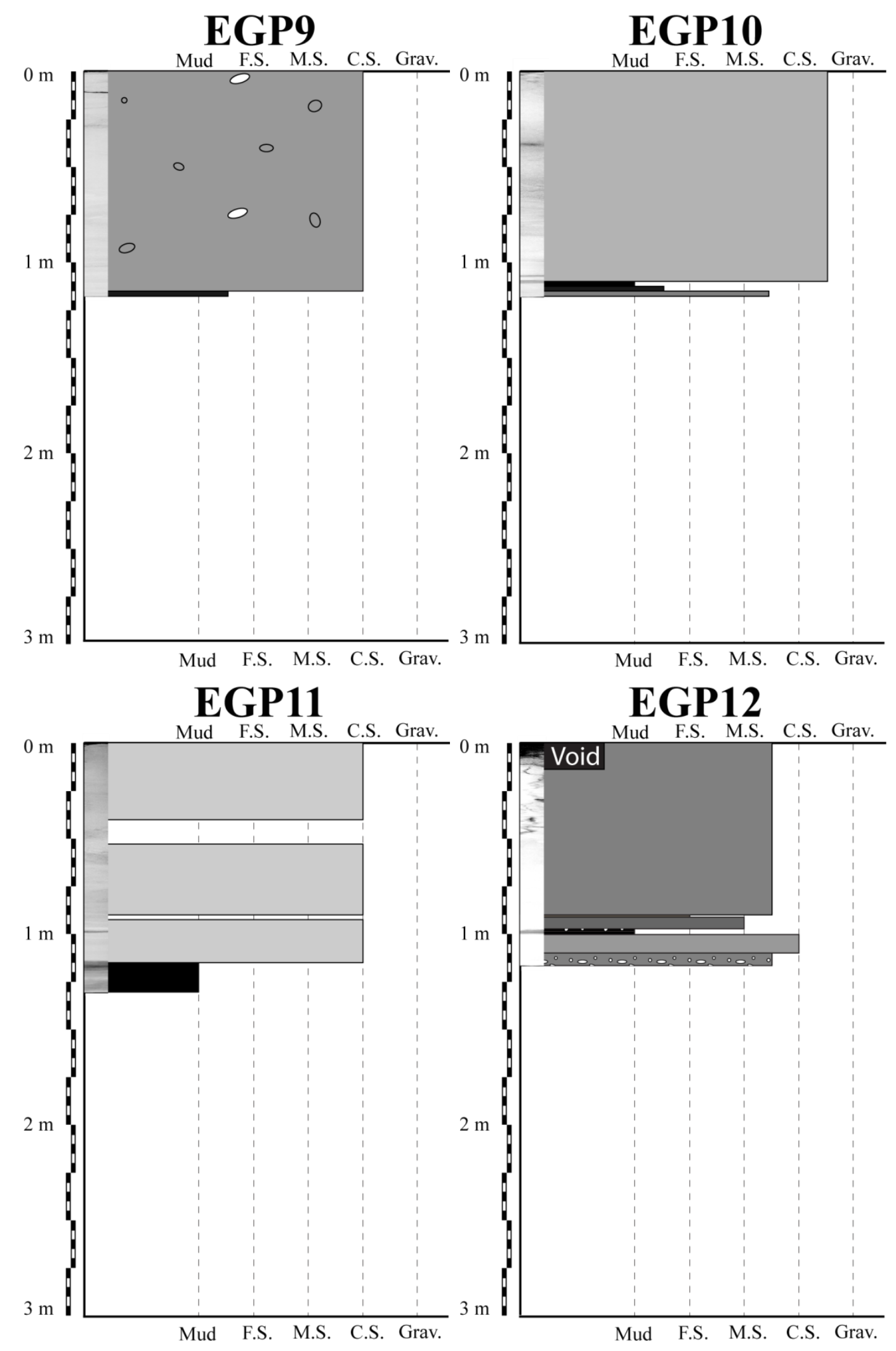


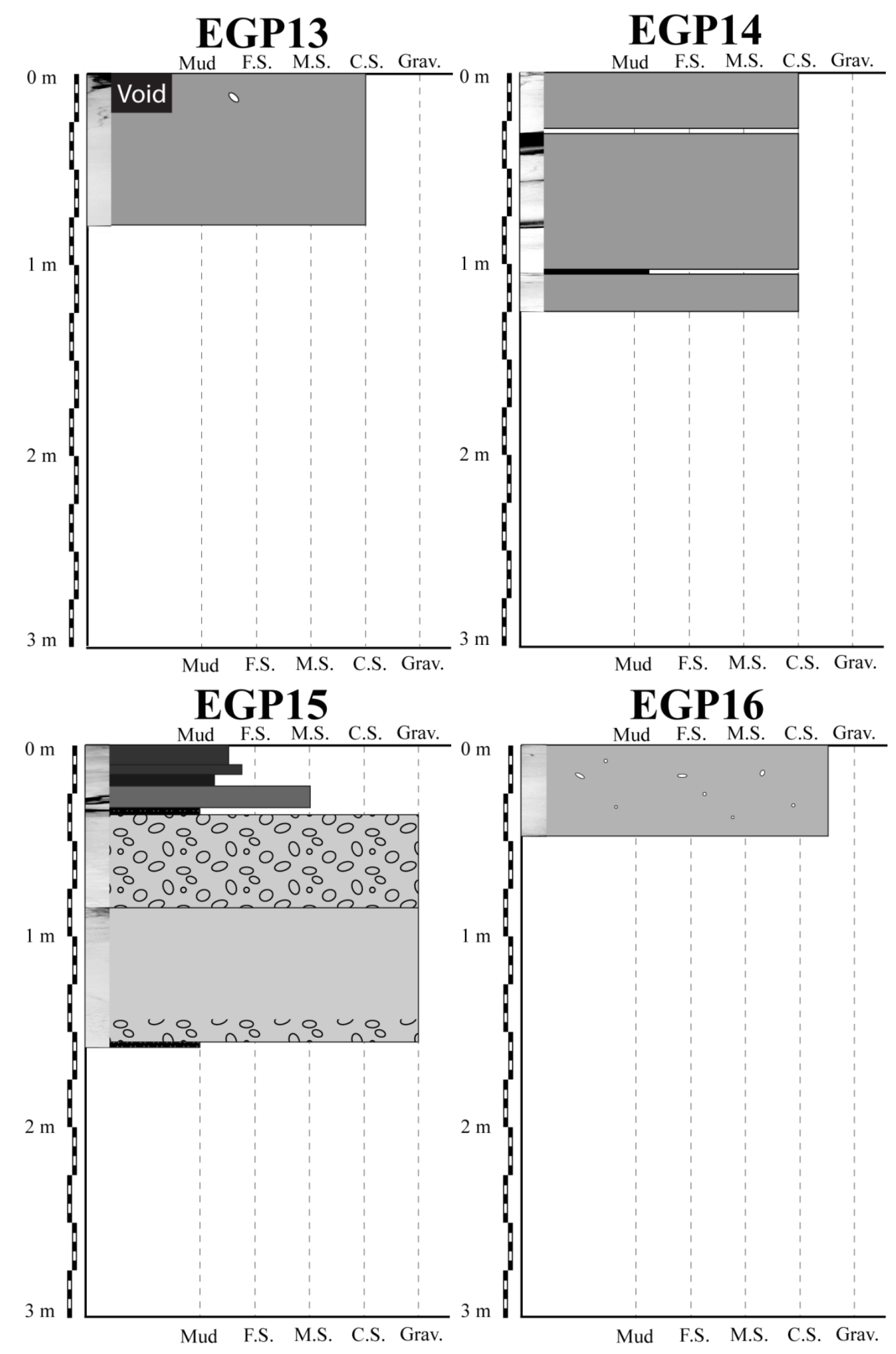


EGP1

\begin{tabular}{|c|c|c|c|c|c|}
\hline section & start & end & grain size & color & comments \\
\hline $1: 1$ & 0 & 63 & vc sand & $2.5 Y 6 / 3$ & \\
\hline & 63 & 116 & vc sand & $2.5 Y 6 / 3$ & $\begin{array}{c}\text { same as above but core is only } 1 / 3 \\
\text { full, } 85 \mathrm{~cm} \text { is approximately end if } \\
\text { core was full }\end{array}$ \\
\hline
\end{tabular}

\section{EGP2}

\begin{tabular}{|c|c|c|c|c|c|}
\hline section & start & end & grain size & color & comments \\
\hline $1: 1$ & 0 & 78 & c sand & $2.5 Y 5 / 3$ & $\begin{array}{c}\text { entire core is one unit; very } \\
\text { occasional shell fragments }\end{array}$ \\
\hline
\end{tabular}

\section{EGP3}

\begin{tabular}{|c|c|c|c|c|c|}
\hline section & start & end & grain size & color & comments \\
\hline $1: 1$ & 0 & 0.5 & clay & $5 Y 4 / 2$ & modern mud \\
\hline & 0.5 & 120 & c sand & $2.5 Y 5 / 3$ & $\begin{array}{c}\text { massive unit; some heavies, not in } \\
\text { well defined layers }\end{array}$ \\
\hline & 120 & 122 & silty mud & $2.5 Y 3 / 2$ & gradational bottom contact \\
\hline & 122 & 124.5 & f sand & $10 Y R 4 / 4$ & $\begin{array}{c}\text { some decomposed organic } \\
\text { discolorations }\end{array}$ \\
\hline & 124.5 & 126 & silty clay & $10 Y R 3 / 4$ & $\begin{array}{c}\text { gradational bottom contact; some } \\
\text { decomposed organics (spots) }\end{array}$ \\
\hline & 126 & 134 & c sand & $2.5 Y 4 / 3$ & end of core \\
\hline
\end{tabular}

EGP4

\begin{tabular}{|c|c|c|c|c|c|}
\hline section & start & end & grain size & color & comments \\
\hline $1: 1$ & 0 & 69 & c/vc sand & $2.5 Y 4 / 3$ & $\begin{array}{c}\text { entire core is one unit; whole } \\
\text { articulated shell at } 55-60 \mathrm{~cm}\end{array}$ \\
\hline
\end{tabular}

EGP5

\begin{tabular}{|c|c|c|c|c|c|}
\hline section & start & end & grain size & color & comments \\
\hline $1: 1$ & 0 & 74 & vc sand & $2.5 Y 5 / 3$ & $\begin{array}{c}\text { entire core is one unit; some } \\
\text { granules mixed in; some black heavy } \\
\text { minerals mixed in 13-20cm }\end{array}$ \\
\hline
\end{tabular}


EGP6

\begin{tabular}{|c|c|c|c|c|c|}
\hline section & start & end & grain size & color & comments \\
\hline $1: 1$ & 0 & 109 & c/vc sand & $2.5 Y 5 / 3$ & $\begin{array}{c}\text { some areas of different color } \\
(2.5 Y 5 / 2) \text { especially } 29-51 \mathrm{~cm} ; 1 \text { by } \\
2 \mathrm{~cm} \text { pebble at } 79 \mathrm{~cm}\end{array}$ \\
\hline & 109 & 111.5 & silty clay & $10 \mathrm{YR} 3 / 4$ & $\begin{array}{c}\text { slightly deformed on one side; } \\
\text { some decomposed organics mixed } \\
\text { in }\end{array}$ \\
\hline & 111.5 & 112.5 & granular & $2.5 Y 5 / 3$ & some pebbles too \\
\hline & 112.5 & 118 & c sand & $2.5 Y 5 / 3$ & $\begin{array}{c}\text { some black heavies throughout, } \\
\text { especially at } 115 \mathrm{~cm}\end{array}$ \\
\hline & 118 & 120 & silty clay & $10 \mathrm{YR} 3 / 4$ & end of core \\
\hline
\end{tabular}

EGP7

\begin{tabular}{|c|c|c|c|c|c|}
\hline section & start & end & grain size & color & comments \\
\hline $1: 1$ & 0 & 90 & vc sand & $2.5 Y 5 / 2$ & $\begin{array}{l}0-16 \mathrm{~cm} \text { has about } 1 / 3 \text { missing, more } \\
\text { like } 10 \mathrm{~cm} \text { thick; all one massive unit }\end{array}$ \\
\hline
\end{tabular}

EGP8

\begin{tabular}{|c|c|c|c|c|c|}
\hline section & start & end & grain size & color & comments \\
\hline $1: 2$ & 0 & 72 & c sand & $2.5 Y 5 / 3$ & $\begin{array}{l}\text { massive unit, some clay at } 39-41 \mathrm{~cm} ; \\
\text { some small pebbles mixed in } 45 \mathrm{~cm} \\
\text { to end }\end{array}$ \\
\hline \multirow[t]{7}{*}{$2: 2$} & 0 & 52 & c sand & $2.5 Y 5 / 3$ & $\begin{array}{c}\text { continuation of layer from previous } \\
\text { section }\end{array}$ \\
\hline & 52 & 56.5 & silty clay & $2.5 Y 3 / 1$ & \\
\hline & 56.5 & 58.5 & c sand & $2.5 Y 5 / 6$ & \\
\hline & 58.5 & 59.5 & silty clay & $2.5 Y 3 / 3$ & \\
\hline & 59.5 & 61 & $\mathrm{~m} / \mathrm{f}$ sand & $2.5 Y 4 / 3$ & \\
\hline & 61 & 63 & silty clay & $2.5 Y 3 / 3$ & $\begin{array}{c}\text { gradational bottom transition from } \\
63-65 \mathrm{~cm} \text {; layer had decomposed } \\
\text { organics }\end{array}$ \\
\hline & 63 & 71 & c sand & $2.5 Y 3 / 3$ & end of core \\
\hline
\end{tabular}


EGP9

\begin{tabular}{|c|c|c|c|c|c|}
\hline section & start & end & grain size & color & comments \\
\hline $1: 1$ & 0 & 115 & c sand & $2.5 Y 6 / 3$ & $\begin{array}{c}\text { some pebbles; shell at } 75 \mathrm{~cm} \text { and } \\
\text { large whole shell half at } 3-8 \mathrm{~cm}\end{array}$ \\
\hline & 115 & 118 & f sandy silt & $2.5 Y 3 / 3$ & sharp contact, end of core \\
\hline
\end{tabular}

EGP10

\begin{tabular}{|c|c|c|c|c|c|}
\hline section & start & end & grain size & color & comments \\
\hline $1: 1$ & 0 & 110.5 & vc sand & $2.5 Y 6 / 3$ & poorly sorted, some granules \\
\hline & 110.5 & 112 & silty clay & $2.5 Y 3 / 3$ & sharp contact above \\
\hline & 112 & 115 & f sandy silt & $2.5 Y 4 / 4$ & \\
\hline & 115 & 122 & $\mathrm{~m} / \mathrm{c}$ sand & $2.5 Y 4 / 3$ & $\begin{array}{c}\text { gradational color from above to } \\
117 \mathrm{~cm} \text {; end of core }\end{array}$ \\
\hline
\end{tabular}

EGP11

\begin{tabular}{|c|c|c|c|c|c|}
\hline section & start & end & grain size & color & comments \\
\hline \multirow[t]{5}{*}{$1: 1$} & 0 & 41 & c sand & $2.5 Y 5 / 3$ & \\
\hline & 41 & 53 & & & clean gap in core \\
\hline & 53 & 115 & c sand & $2.5 Y 5 / 3$ & clean gap in core $90-93 \mathrm{~cm}$ \\
\hline & 101 & 102 & silt & $7.5 Y R 2.5 / 2$ & $\begin{array}{l}\text { possibly organic rich, blob in } \\
\text { center of core possibly a chunk of } \\
\text { marsh reworked during overwash }\end{array}$ \\
\hline & 115 & 130.5 & silty clay & $2.5 Y 3 / 3$ & $\begin{array}{c}\text { clean sharp contact above, end of } \\
\text { core }\end{array}$ \\
\hline
\end{tabular}


EGP12

\begin{tabular}{|c|c|c|c|c|c|}
\hline section & start & end & grain size & color & comments \\
\hline $1: 1$ & 0 & 89 & $\mathrm{~m} / \mathrm{c}$ sand & $2.5 Y 6 / 3$ & $\begin{array}{c}\text { one third of sed lost from top } \\
14 \mathrm{~cm} \text {, might have just have } \\
\text { settled }\end{array}$ \\
\hline & 89 & 90 & $\mathrm{f}$ sand & $2.5 Y 4 / 1$ & $\begin{array}{c}\text { very sharp top contact, } \\
\text { gradational bottom contact }\end{array}$ \\
\hline & 90 & 97 & $\mathrm{~m}$ sand & $2.5 Y 5 / 3$ & sharp contact on bottom \\
\hline & 97 & 98 & clay & $5 \mathrm{Y} 3 / 1$ & with shell hash \\
\hline & 98 & 100 & silty clay & $2.5 Y 3 / 3$ & gradational transition below \\
\hline & 100 & 110 & c sand & $2.5 Y 4 / 3$ & sharp contact at bottom \\
\hline & 110 & 116 & $\mathrm{~m} / \mathrm{c}$ sand & $5 Y 4 / 2$ & shell hash; end of core \\
\hline
\end{tabular}

EGP13

\begin{tabular}{|c|c|c|c|c|c|}
\hline section & start & end & grain size & color & comments \\
\hline $1: 1$ & 0 & 79 & c sand & $2.5 Y 4 / 3$ & $\begin{array}{c}\text { whole core is one unit, shell frag at } \\
13 \mathrm{~cm},<1 / 2 \text { of sed is missing from } \\
0-20 \mathrm{~cm} \text { (section is possibly } \sim 5 \mathrm{~cm} \\
\text { shorter) }\end{array}$ \\
\hline
\end{tabular}

\section{EGP14}

\begin{tabular}{|c|c|c|c|c|c|}
\hline section & start & end & grain size & color & comments \\
\hline $1: 1$ & 0 & 103 & c sand & $2.5 Y 5 / 3$ & $\begin{array}{c}2 \mathrm{~cm} \text { gap 27-29cm, } .5 \mathrm{~cm} \text { gap } 36- \\
36.5 \mathrm{~cm} \text { (core just slid) }\end{array}$ \\
\hline & 103 & 106 & silty vf sand & $5 Y 3 / 2$ & $\begin{array}{c}\text { some organic pieces that are } \\
\text { partially decomposed }\end{array}$ \\
\hline & 106 & 125 & c sand & $2.5 Y 5 / 3$ & end of core \\
\hline
\end{tabular}


EGP15

\begin{tabular}{|c|c|c|c|c|c|}
\hline section & start & end & grain size & color & comments \\
\hline \multirow[t]{6}{*}{$1: 2$} & 0 & 11 & silty f sand & $5 Y 4 / 2$ & \\
\hline & 11 & 14 & silty $f$ sand & $5 Y 4 / 2$ & a bit sandier than above \\
\hline & 14 & 22 & silty $f$ sand & $5 Y 4 / 2$ & very silty, little sand \\
\hline & 22 & 32 & $\mathrm{~m}$ sand & $2.5 Y 5 / 6$ & \\
\hline & 32 & 36 & m sandy silt & $5 Y 2.5 / 2$ & \\
\hline & 36 & 86 & granular & $2.5 Y 4 / 2$ & $\begin{array}{l}\text { lots of pebbles, especially at } 81 \mathrm{~cm}- \\
\text { end, size grades from top to } 42 \mathrm{~cm}\end{array}$ \\
\hline \multirow[t]{2}{*}{$2: 2$} & 0 & 70 & granular & $2.5 Y 4 / 2$ & $\begin{array}{c}\text { pebbles in pockets especially at } \\
58-70 \mathrm{~cm}\end{array}$ \\
\hline & 70 & 72 & vc sandy silt & $2.5 Y 4 / 1$ & $\begin{array}{l}\text { very poorly sorted, could be } \\
\text { transition to mud layer beneath }\end{array}$ \\
\hline
\end{tabular}

EGP16

\begin{tabular}{|c|c|c|c|c|c|}
\hline section & start & end & grain size & color & comments \\
\hline $1: 1$ & 0 & 48 & vc sand & $2.5 Y 5 / 2$ & $\begin{array}{c}\text { entire core is one unit; large shell } \\
\text { fragments at 14-18cm; some } \\
\text { occasional shell pieces throughout }\end{array}$ \\
\hline
\end{tabular}

